Cover: Photograph of the northern cliffs of Black Mesa on Indian Route 59 near Rough Rock on the Navajo Indian Reservation, Arizona. (Photograph taken by Margot Truini, U.S. Geological Survey, Flagstaff, Arizona, 2006.) 


\section{Ground-Water, Surface-Water, and Water-Chemistry Data, Black Mesa Area, Northeastern Arizona-2004-05}

By Margot Truini and J.P. Macy

Prepared in cooperation with the

Bureau of Indian Affairs and the

Arizona Department of Water Resources

Open-File Report 2006-1058 


\section{U.S. Department of the Interior \\ P. Lynn Scarlett, Acting Secretary}

\section{U.S. Geological Survey \\ P. Patrick Leahy, Acting Director}

U.S. Geological Survey, Reston, Virginia: 2006

For sale by U.S. Geological Survey, Information Services
Box 25286, Denver Federal Center
Denver, CO 80225
For more information about the USGS and its products:
Telephone: 1-888-ASK-USGS
World Wide Web: http://www.usgs.gov/

Any use of trade, product, or firm names in this publication is for descriptive purposes only and does not imply endorsement by the U.S. Government.

Although this report is in the public domain, permission must be secured from the individual copyright owners to reproduce any copyrighted materials contained within this report.

Suggested citation:

Truini, Margot, and Macy, J.P., 2006, Ground-water, surface-water, and water-chemistry data, Black Mesa area, northeastern Arizona-2004-05: U.S. Geological Survey Open-File Report 2006-1058, 42 p. 


\section{Contents}

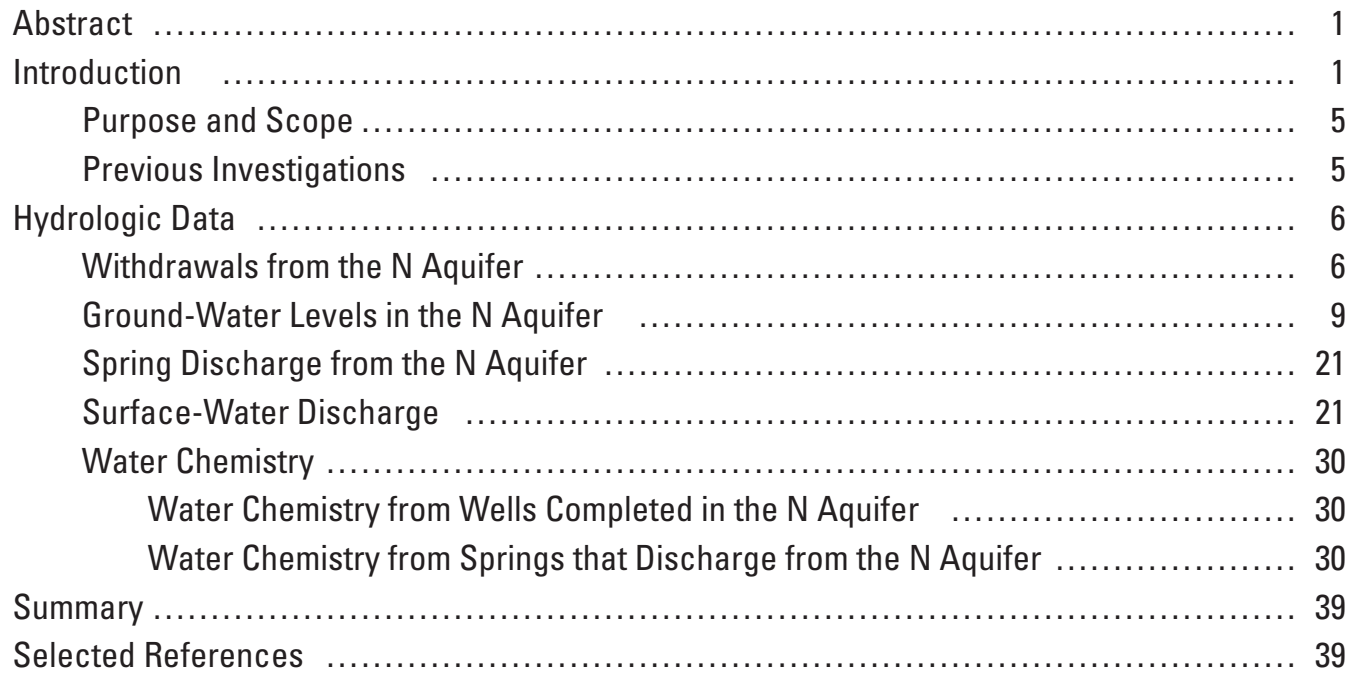

\section{Figures}

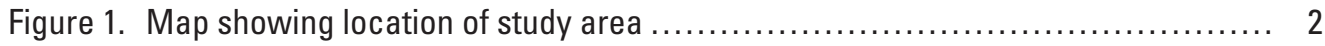

Figure 2. Section showing rock formations and hydrogeologic units of the Black Mesa area, Arizona

Figure 3. Graph showing withdrawals from the $\mathrm{N}$ aquifer, Black Mesa area, Arizona, 1965-2004

Figure 4. Map showing locations of well systems monitored for withdrawals from the N aquifer, Black Mesa area, Arizona, 2004

Figure 5. MAp showing water-level changes in $\mathrm{N}$ aquifer wells from the prestress period to 2005, Black Mesa area, Arizona .................................. 10

Figure 6. Graph showing annual median water-level changes for observation wells completed in the N aquifer, Black Mesa area, Arizona, 1983-2005

Figure 7. Graphs showing observed water levels (1950-2005) in annual observation well network, Black Mesa area, Arizona

Figure 8. Graphs showing observed water-level changes in continuous-record observation wells, BM1-BM6, 1963-2005, Black Mesa area, Arizona

Figure 9. Map showing surface-water and water-chemistry data-collection sites, Black Mesa area, Arizona, 2004-05

Figure 10. Graph showing discharge from selected springs, Black Mesa area, 


\section{Figures-Continued}

Figure 11. Graphs showing annual precipitation at Betatakin, Arizona, and streamflow characteristics at Moenkopi Wash (09401260), Laguna Creek (09379180), Dinnebito Wash (09401110), and Polacca Wash (09400568), Black Mesa area, Arizona

Figure 12. Map showing water chemistry and distribution of dissolved solids in the $\mathrm{N}$ aquifer, Black Mesa area, Arizona, 2005

Figure 13. Graph showing dissolved-solids concentrations with linear trend lines for water from selected wells, Black Mesa area, Arizona, 1980-2005 35

Figure 14. Graph showing concentrations of dissolved solids, chloride, and sulfate for water from selected springs, Black Mesa area, Arizona, 1984-2005. ... 38

\section{Tables}

Table 1. Withdrawals from the N aquifer, Black Mesa area, Arizona, 1965-2004

Table 2. Identification numbers and names of study wells, 2004-05, Black Mesa area, Arizona

Table 3. Withdrawals from the $\mathrm{N}$ aquifer by well system, Black Mesa area, Arizona, 2004

Table 4. Withdrawals from the $\mathrm{N}$ aquifer by water-use category for 1965-2004 and for other periods, Black Mesa, Arizona .....

Table 5. Water-level changes in wells completed in the $\mathrm{N}$ aquifer, Black Mesa area, Arizona, prestress period to 2005

Table 6. Well-construction characteristics, depth to top of $\mathrm{N}$ aquifer, and type of data collected for wells in monitoring program, Black Mesa area, Arizona, 2004-05

Table 7. Median changes in water levels, 2004-05 and prestress period to 2005, Black Mesa area, Arizona

Table 8. Discharge measurements of selected springs, Black Mesa area, Arizona, 1952-2005

Table 9. Discharge data, Moenkopi Wash at Moenkopi, Arizona (09401260), calendar year 2004

Table 10. Discharge data, Laguna Creek at Dennehotso, Arizona (09379180), calendar year 2004

Table 11. Discharge data, Dinnebito Wash near Sand Springs, Arizona (09401110), calendar year 2004 25

Table 12. Discharge data, Polacca Wash near Second Mesa, Arizona (09400568), calendar year 2004

Table 13. Discharge data, Pasture Canyon Spring near Tuba City, Arizona (09401265), August through December, calendar year 2004.

Table 14. Date that data collection began and drainage areas for streamflow-gaging stations, Black Mesa area, Arizona 


\section{Tables-Continued}

Table 15. Physical properties and chemical analyses of water from selected industrial and municipal wells completed in the $\mathrm{N}$ aquifer, Black Mesa area, Arizona, 2005

Table 16. Specific conductance and concentrations of selected chemical constituents in water from industrial and municipal wells completed in the $\mathrm{N}$ aquifer, Black Mesa area, Arizona, 1974-2005

Table 17. Physical properties and chemical analyses of water from selected springs that discharge from the $\mathrm{N}$ aquifer, Black Mesa area, Arizona, 2005

Table 18. Specific conductance and concentrations of selected chemical constituents in water from selected springs that discharge from the $\mathrm{N}$ aquifer, Black Mesa area, Arizona, 1948-2005

\section{Conversion Factors and Datums}

Conversion Factors

\begin{tabular}{lll}
\hline Multiply & By & To obtain \\
\hline acre-foot (acre-ft) & 0.001233 & cubic hectometer $\left(\mathrm{hm}^{3}\right)$ \\
cubic foot per second $\left(\mathrm{ft}^{3} / \mathrm{s}\right)$ & 0.02832 & cubic meter per second $\left(\mathrm{m}^{3} / \mathrm{s}\right)$ \\
foot $(\mathrm{ft})$ & 0.3048 & meter $(\mathrm{m})$ \\
gallon per day $(\mathrm{gal} / \mathrm{d})$ & 0.003785 & cubic meter per day $\left(\mathrm{m}^{3} / \mathrm{d}\right)$ \\
gallon per minute $(\mathrm{gal} / \mathrm{min})$ & 0.06309 & liter per second $(\mathrm{L} / \mathrm{s})$ \\
inch (in.) & 2.54 & centimeter $(\mathrm{cm})$ \\
inch (in.) & 25.4 & millimeter $(\mathrm{mm})$ \\
mile (mi) & 1.609 & kilometer $(\mathrm{km})$ \\
square mile $\left(\mathrm{mi}^{2}\right)$ & 2.590 & square kilometer $\left(\mathrm{km}^{2}\right)$ \\
\hline
\end{tabular}

Temperature in degrees Celsius $\left({ }^{\circ} \mathrm{C}\right)$ may be converted to degrees Fahrenheit $\left({ }^{\circ} \mathrm{F}\right)$ as follows:

$$
{ }^{\circ} \mathrm{F}=\left(1.8 x^{\circ} \mathrm{C}\right)+32 \text {. }
$$

Specific conductance is given in microsiemens per centimeter at 25 degrees Celsius $(\mu \mathrm{S} / \mathrm{cm}$ at $\left.25^{\circ} \mathrm{C}\right)$.

Concentrations of chemical constituents in water are given either in milligrams per liter (mg/L) or micrograms per liter $(\mu \mathrm{g} / \mathrm{L})$.

Datums

Vertical coordinate information is referenced to the National Geodetic Vertical Datum of 1929 (NGVD 29).

Horizontal coordinate information is referenced to the North American Datum of 1927 (NAD 27). Elevation, as used in this report, refers to distance above the vertical datum. 
This page is intentionally left blank. 


\title{
Ground-Water, Surface-Water, and Water-Chemistry Data, Black Mesa Area, Northeastern Arizona-2004-05
}

\author{
By Margot Truini and J.P. Macy
}

\section{Abstract}

The $\mathrm{N}$ aquifer is the major source of water in the 5,400-square-mile area of Black Mesa in northeastern Arizona. Availability of water is an important issue in this area because of continued industrial and municipal use, a growing population, and precipitation of about 6 to 14 inches per year.

The monitoring program in the Black Mesa area has been operating since 1971 and is designed to determine the long-term effects of ground-water withdrawals from the $\mathrm{N}$ aquifer for industrial and municipal uses. The monitoring program includes measurements of (1) ground-water pumping, (2) ground-water levels, (3) spring discharge, (4) surface-water discharge, (5) ground-water chemistry, and (6) periodic testing of ground-water withdrawal meters.

In 2004, total ground-water withdrawals were 7,210 acre-feet, industrial withdrawals were 4,370 acre-feet, and municipal withdrawals were 2,840 acre-feet. From 2003 to 2004 , total withdrawals decreased by less than 1 percent, industrial withdrawals decreased by 2 percent, and municipal withdrawals increased by 2 percent.

From 2004 to 2005, annually measured water levels declined in 6 of 13 wells in the unconfined areas of the aquifer, and the median change was -0.1 foot. Water levels declined in 8 of 12 wells in the confined area of the aquifer, and the median change was -1.2 feet. From the prestress period (prior to 1965 ) to 2005 , the median water-level change for 33 wells was -9.0 feet. Median water-level changes were -0.6 foot for 16 wells in the unconfined areas and -32.0 feet for 17 wells in the confined area.

Discharges were measured once in 2004 and once in 2005 at four springs. Discharge increased by 8 percent at Pasture Canyon Spring, decreased by 5 percent at Moenkopi School Spring, increased by 71 percent at an unnamed spring near Dennehotso, and stayed the same at Burro Spring. For the period of record at each spring, discharges from the four springs have fluctuated; however, an increasing or decreasing trend is not apparent.

Continuous records of surface-water discharge have been collected from 1976 to 2004 at Moenkopi Wash, 1996 to 2004 at Laguna Creek, 1993 to 2004 at Dinnebito Wash, 1994 to 2004 at Polacca Wash, and August 2004 to December
2004 at Pasture Canyon Spring. Median flows for November, December, January, and February of each water year were used as an index of ground-water discharge to those streams. Since 1995, the median winter flows have decreased for Moenkopi Wash, Dinnebito Wash, and Polacca Wash. Since the first continuous record of surface-water discharge in 1997, there is no consistent trend in the median winter flow for Laguna Creek.

In 2005, water samples were collected from 11 wells and 4 springs and analyzed for selected chemical constituents. Dissolved-solids concentrations ranged from 122 to 639 milligrams per liter. Water samples from 9 of the wells and from all the springs had less than 500 milligrams per liter of dissolved solids. There are some long-term trends in the chemistry of water samples from 7 wells having more than 10 years of data and from 2 springs. Rough Rock PM5, Keams Canyon PM2, Second Mesa PM2, and Kayenta PM2 show an increasing trend in dissolved solids; Forest Lake NTUA1 and PWCC 2 show a decreasing trend in dissolved solids; and Kykostmovi PM2 shows a steady trend. Increasing trends in dissolved-solids and chloride concentrations were evident from the more than 11 years of data for 2 springs.

\section{Introduction}

The Black Mesa study area includes about $5,400 \mathrm{mi}^{2}$ in northeastern Arizona (fig. 1) and has a diverse topography that includes flat plains, mesas, and incised drainages. Black Mesa is about 2,000 $\mathrm{mi}^{2}$, is bounded by 2,000-foot cliffs on the north and northeast sides, and slopes gradually down in elevation to the south and southwest. Availability of water is an important issue in the study area because of continued ground-water withdrawals, a growing population, and precipitation that averages about 6 to 14 in./yr (U.S. Department of Agriculture, 1999). The $\mathrm{N}$ aquifer is the major source of water for industrial and municipal uses in the Black Mesa area. It consists of three formations-the Navajo Sandstone, the Kayenta Formation, and the Lukachukai Member of the Wingate Sandstone-that are hydraulically connected and function as a single aquifer (fig. 2). 


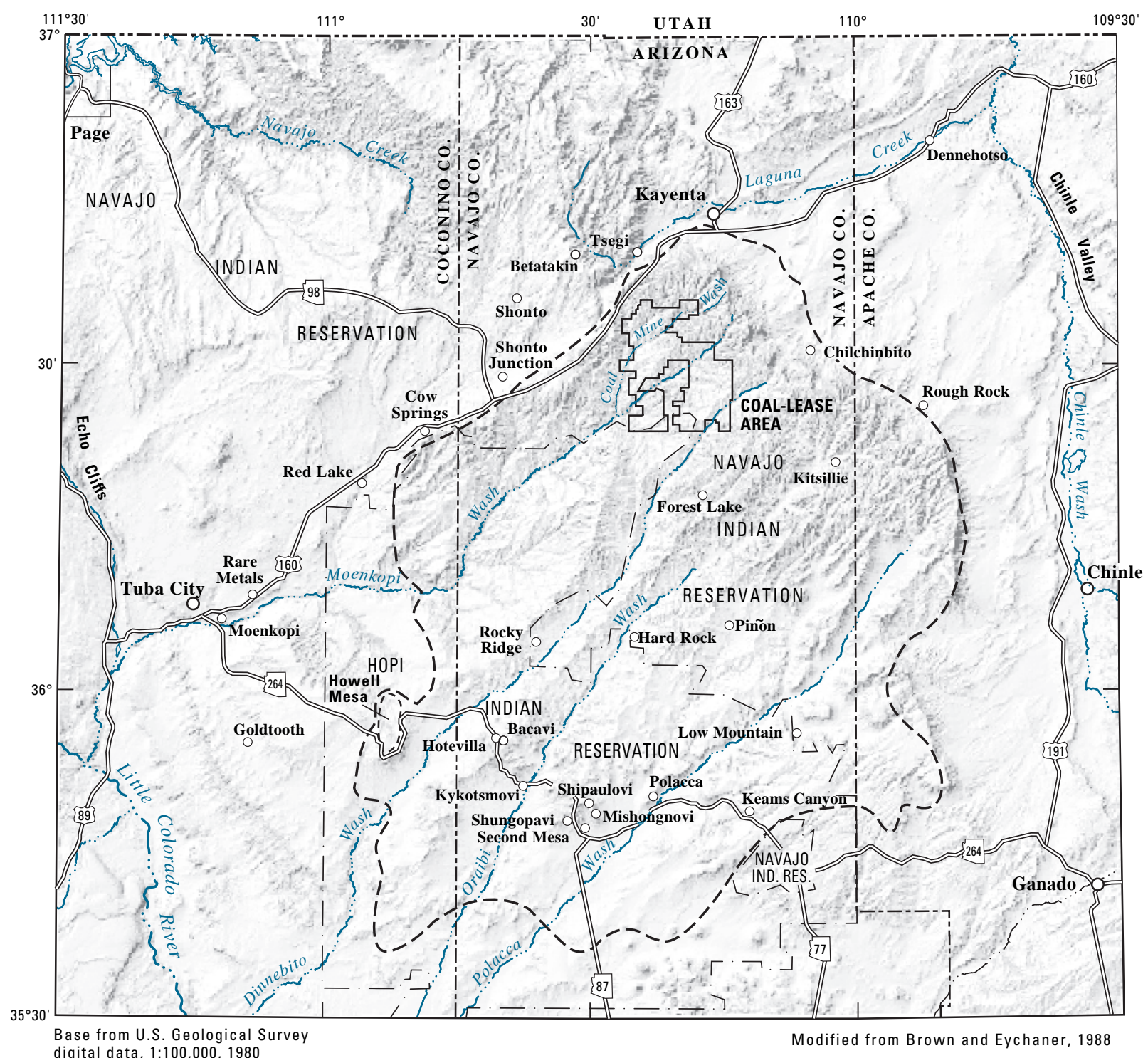

digital data, $1: 100,000,1980$

Lambert Conformal Conic projection

Standard parallels $29^{\circ} 30^{\prime}$ and $45^{\circ} 30^{\prime}$,

central meridian $-111^{\circ} 30^{\prime}$
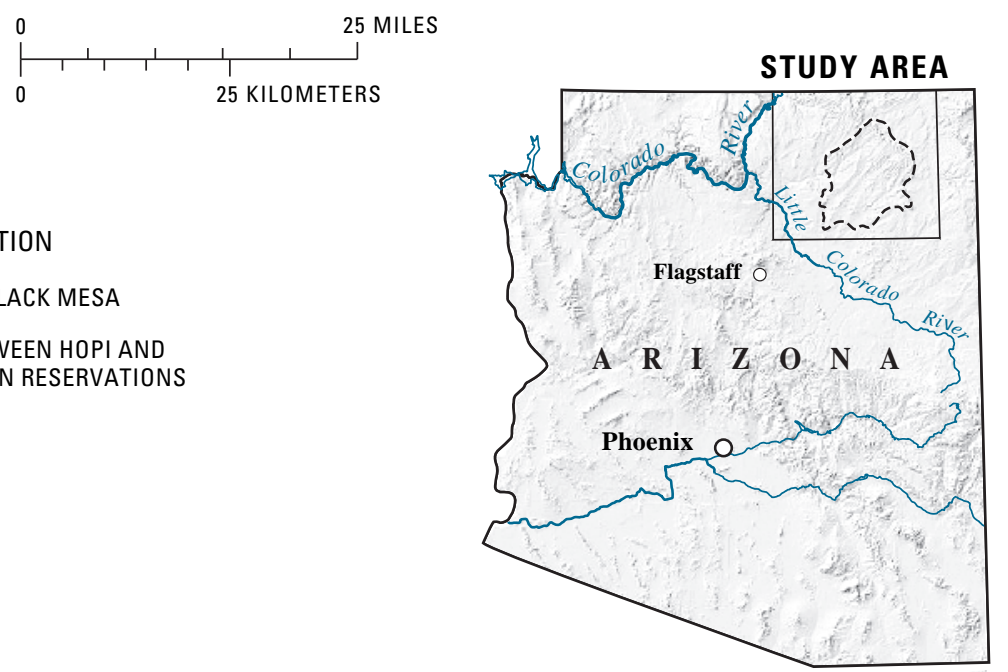

Figure 1. Location of study area. 


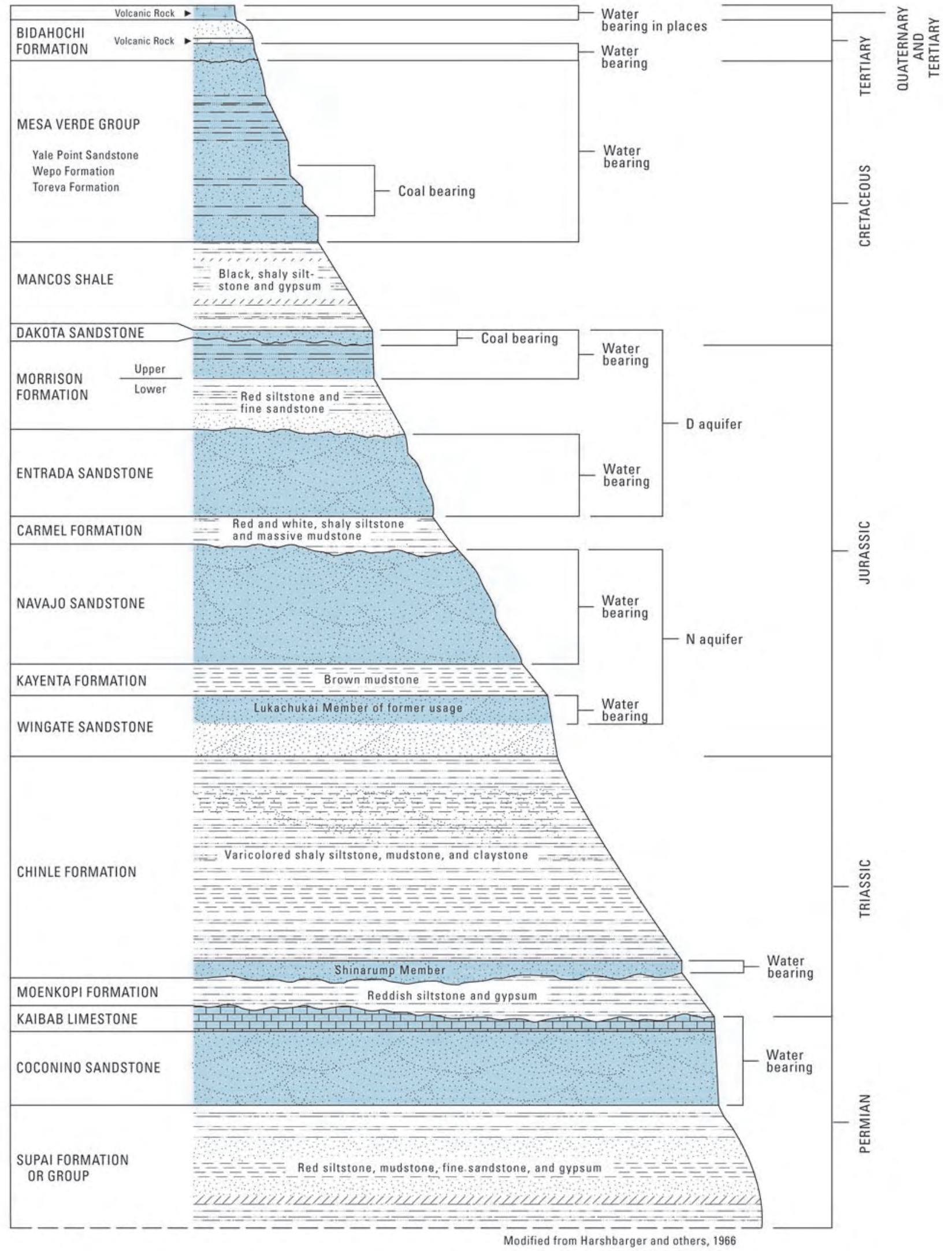

Figure 2. Rock formations and hydrogeologic units of the Black Mesa area, Arizona (not to scale). 
Within the Black Mesa study area, Peabody Western Coal Company (PWCC) is the principal industrial water user, and the Navajo Nation and Hopi Tribe are the principal domestic and municipal water users. Withdrawals from the $\mathrm{N}$ aquifer in the Black Mesa area have been increasing during the last 34 years (table 1 and fig. 3). PWCC began operating a strip mine in the northern part of the mesa in 1968. The quantity of water pumped by PWCC increased from about 100 acre-ft in 1968 to a maximum of 4,740 acre-ft in 1982. About 4,370 acre-ft of water was pumped in 2004 by PWCC. Withdrawals for municipal use from the $\mathrm{N}$ aquifer increased from an estimated 250 acre-ft in 1968 to 2,840 acre-ft in 2004. The period before appreciable ground-water withdrawals began for mining or municipal purposes (about 1965) is referred to in this report as the prestress period.
The Navajo Nation and the Hopi Tribe have been concerned about the long-term effects of withdrawals from the $\mathrm{N}$ aquifer on available water supplies, on stream and spring discharge, and on ground-water chemistry. In 1971, these concerns led to the establishment of a monitoring program of the water resources in the Black Mesa area by the U.S. Geological Survey (USGS) in cooperation with the Arizona Department of Water Resources (ADWR). In 1983, the Bureau of Indian Affairs (BIA) joined the cooperative effort. Since 1983, the Navajo Tribal Utility Authority (NTUA); PWCC; the Hopi Tribe; and the Western Navajo Agency, the Chinle Agency, and the Hopi Agency of the BIA have assisted in the collection of hydrologic data.

Table 1. Withdrawals from the N aquifer, Black Mesa area, Arizona, 1965-2004.

[Values are rounded to nearest 10 acre-feet. Data for 1965-79 from Eychaner (1983). Total withdrawals in Littin and Monroe (1996) were for the confined area of the aquifer]

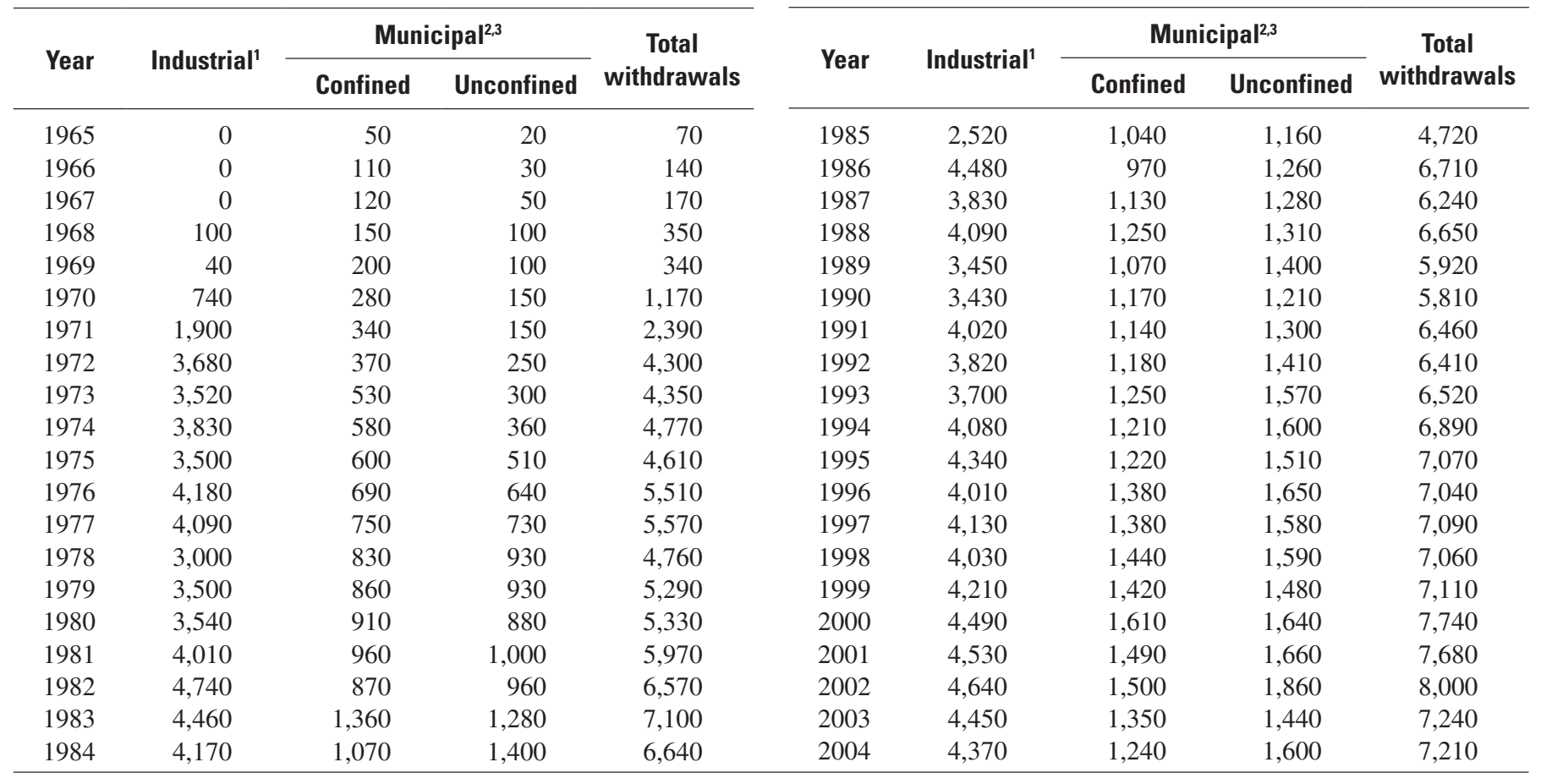

${ }^{1}$ Metered pumpage from the confined area of the aquifer by Peabody Western Coal Company.

${ }^{2}$ Does not include withdrawals from the wells equipped with windmills.

${ }^{3}$ Includes estimated pumpage, 1965-73, and metered pumpage, 1974-79, at Tuba City; metered pumpage at Kayenta and estimated pumpage at Chilchinbito, Rough Rock, Piñon, Keams Canyon, and Kykotsmovi before 1980; metered and estimated pumpage furnished by the Navajo Tribal Utility Authority and the Bureau of Indian Affairs and collected by the U.S. Geological Survey, 1980-85; and metered pumpage furnished by the Navajo Tribal Utility Authority, the Bureau of Indian Affairs, various Hopi Village Administrations, and the U.S. Geological Survey, 1986-2004. 


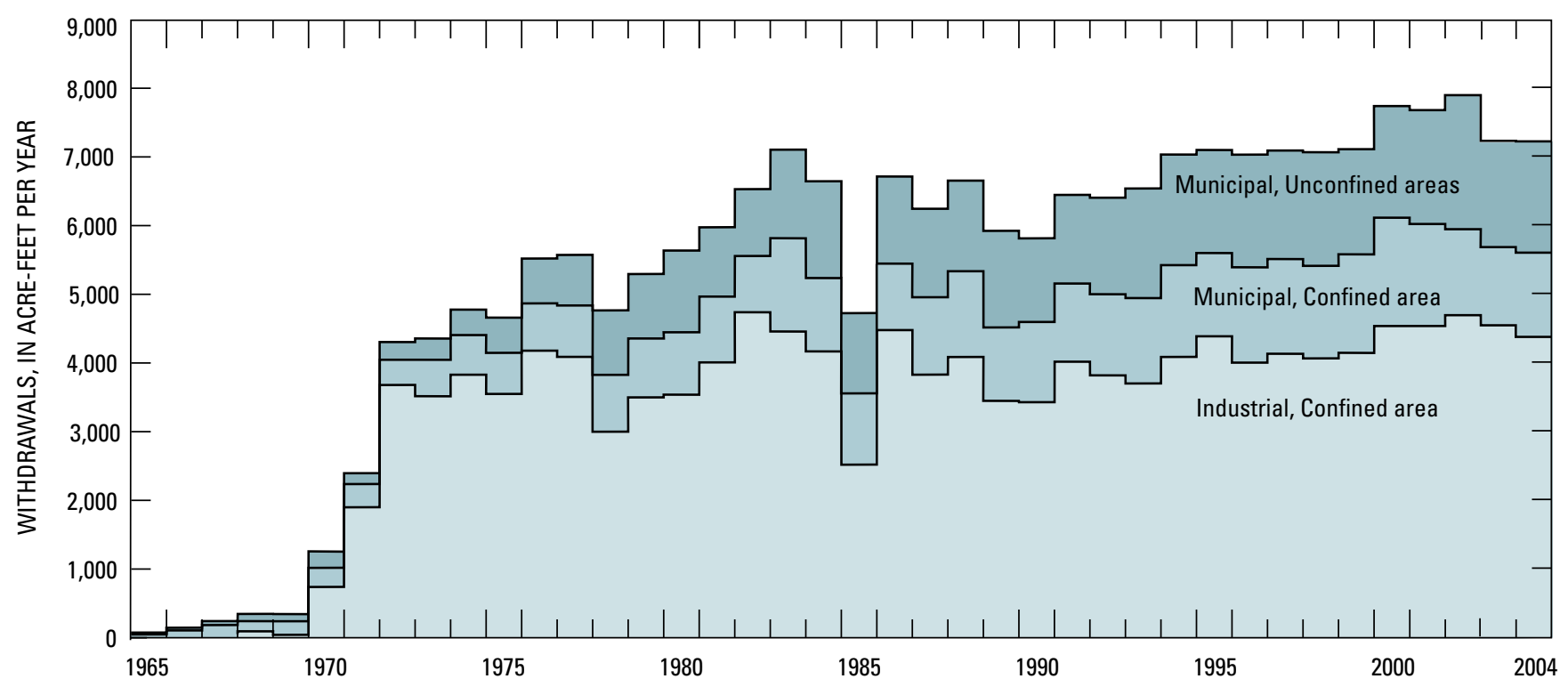

Figure 3. Withdrawals from the $\mathrm{N}$ aquifer, Black Mesa area, Arizona, 1965-2004.

\section{Purpose and Scope}

This report presents results of ground-water, surfacewater, and water-chemistry monitoring in the Black Mesa area from January 2004 to September 2005. The monitoring is designed to determine the effects of industrial and municipal pumpage from the $\mathrm{N}$ aquifer on ground-water levels, stream and spring discharge, and ground-water chemistry. Continuous and periodic data are collected for ground water and surface water. Ground-water data include pumpage, water levels, spring discharges, and water chemistry. Surface-water data include discharges at four continuous-record streamflowgaging stations.

\section{Previous Investigations}

Twenty-two progress reports on the monitoring program for the Black Mesa area have been prepared by the USGS (U.S. Geological Survey, 1978; G.W. Hill, Hydrologist, written commun., 1982, 1983; Hill, 1985; Hill and Whetten, 1986; Hill and Sottilare, 1987; Hart and Sottilare, 1988, 1989; Sottilare, 1992; Littin, 1992, 1993; Littin and Monroe, 1995a, 1995b, 1996, 1997; Littin and others, 1999; Truini and others, 2000; Thomas and Truini, 2000; Thomas, 2002a, 2002b; Truini and Thomas, 2004; and Truini and others, 2005). Most of the data from the monitoring program are contained in these reports. Stream-discharge and periodic water-quality data from Moenkopi Wash collected before the 1982 water year were published by the USGS (1963-64a, b; 1965-74a, b; and 1976-83). Stream-discharge data from water years 1983 to 2003 for Moenkopi Wash and other streams in the Black Mesa area were published in White and Garrett (1984, 1986, 1987, and 1988), Wilson and Garrett (1988, 1989), Boner and others
(1989, 1990, 1991, 1992), Smith and others (1993, 1994, 1995, 1996, 1997), Tadayon and others (1998, 1999, 2000, 2001), McCormack and others (2002, 2003), Fisk and others (2004, 2005). Before the monitoring program, a large datacollection effort in the 1950s resulted in a compilation of well and spring data for the Navajo and Hopi Indian Reservations (Davis and others, 1963).

Many interpretive studies have been done in the Black Mesa area. Cooley and others (1969) made the first comprehensive evaluation of the regional hydrogeology of the Black Mesa area. Eychaner (1983) developed a twodimensional numerical model of ground-water flow in the $\mathrm{N}$ aquifer. Brown and Eychaner (1988) recalibrated the model using a finer grid and revised estimates of selected aquifer characteristics. GeoTrans (1987) also developed a two-dimensional model of the $\mathrm{N}$ aquifer in the 1980s. In the late 1990s, HSIGeoTrans and Waterstone Environmental Hydrology and Engineering (1999) developed a detailed threedimensional numerical model of the $\mathrm{D}$ and $\mathrm{N}$ aquifers.

Kister and Hatchett (1963) made the first comprehensive evaluation of the chemistry of water from wells and springs in the Black Mesa area. HSIGeoTrans (1993) evaluated the major-ion and isotopic chemistry of the D and $\mathrm{N}$ aquifers. Lopes and Hoffmann (1997) analyzed ground-water ages, recharge, and hydraulic conductivity of the $\mathrm{N}$ aquifer using geochemical techniques. Zhu and others (1998) estimated ground-water recharge using isotopic data and flow estimates from the model developed by GeoTrans (1987). Zhu (2000) estimated recharge again using the same isotopic data, but added numerical flow and transport modeling to the method. Truini and Longsworth (2003) described the hydrogeology of the $\mathrm{D}$ aquifer and movement and ages of ground water using geochemical and isotopic analyses. 


\section{Hydrologic Data}

In 2004-05, the Black Mesa monitoring program included metering and estimating ground-water withdrawals, measuring depth to ground water, measuring discharge in streams and springs, and collecting and analyzing water samples from wells and springs. Annual ground-water withdrawals are gathered from 28 well systems within the NTUA, BIA, and Hopi municipal systems and the PWCC industrial well field. Annual measurements of discharge were made at 4 springs, and annual measurements of ground-water levels were made at 33 wells. Spring discharges and groundwater levels were measured between January and May 2005. Ground-water samples were collected from 11 wells and 4 springs in March-May 2005 and analyzed for chemical constituents. Continuous recorders at the 6 observation wells have been upgraded for telemetry, and the water-level data from these wells are available on the World Wide Web (http:// waterdata.usgs.gov/az/nwis/rt). Identification information for the 50 wells used for water-level measurements and waterquality sampling is shown in table 2.

\section{Withdrawals from the N Aquifer}

Withdrawals from the $\mathrm{N}$ aquifer are separated into three categories: (1) industrial withdrawals from the confined area, (2) municipal withdrawals from the confined area, and (3) municipal withdrawals from the unconfined areas (table 1 and fig. 3). The industrial category includes eight wells in the well field of PWCC in northern Black Mesa (fig. 4). The BIA, NTUA, and Hopi Tribe operate about 70 municipal wells that are combined into 28 well systems (fig. 4). Withdrawals from the $\mathrm{N}$ aquifer were compiled primarily on the basis of metered data (tables 1 and 3).

Withdrawals from wells equipped with windmills are not measured in this monitoring program. About 270 windmills in the Black Mesa area withdraw water from the D and $\mathrm{N}$ aquifers, and estimated total withdrawals by the windmills are about 65 acre-ft/yr (HSIGeoTrans, Inc. and Waterstone Environmental Hydrology and Engineering, Inc., 1999). This amount is less than 1 percent of the total annual withdrawal from the $\mathrm{N}$ aquifer.

Table 2. Identification numbers and names of study wells, 2004-05, Black Mesa area, Arizona.

[Dashes indicate no data]

\begin{tabular}{|c|c|c|}
\hline $\begin{array}{l}\text { U.S. Geological Survey } \\
\text { identification No. }\end{array}$ & Common name or location & $\begin{array}{l}\text { Bureau of } \\
\text { Indian Affairs } \\
\text { site No. }\end{array}$ \\
\hline 354749110300101 & Second Mesa PM2 & --- \\
\hline 355023110182701 & Keams Canyon PM2 & --- \\
\hline 355034110183001 & Keams Canyon PM3 & --- \\
\hline 355215110375001 & Kykotsmovi PM2 & --- \\
\hline 355230110365801 & Kykotsmovi PM1 & --- \\
\hline 355236110364501 & Kykotsmovi PM3 & --- \\
\hline 355428111084601 & Goldtooth & $3 \mathrm{~A}-28$ \\
\hline 355518110400301 & Hotevilla PM1 & --- \\
\hline 355638110060401 & Low Mountain PM2 & --- \\
\hline 355648110475501 & Howell Mesa & $6 \mathrm{H}-55$ \\
\hline 355924110485001 & Howell Mesa & $3 \mathrm{~K}-311$ \\
\hline 360055110304001 & BM observation well 5 & $4 \mathrm{~T}-519$ \\
\hline 360217111122601 & Tuba City & $3 \mathrm{~K}-325$ \\
\hline 360418110352701 & Rocky Ridge PM2 & --- \\
\hline 360527110122501 & Piñon NTUA 1 & --- \\
\hline 360614110130801 & Piñon PM6 & --- \\
\hline 360734111144801 & Tuba City & $3 \mathrm{~T}-333$ \\
\hline 360904111140201 & Tuba City NTUA 1 & $3 \mathrm{~T}-508$ \\
\hline 360918111080701 & Tuba City Rare Metals 2 & --- \\
\hline 360924111142201 & Tuba City NTUA 3 & --- \\
\hline 360953111142401 & Tuba City NTUA 4 & $3 \mathrm{~T}-546$ \\
\hline 361225110240701 & BM observation well 6 & --- \\
\hline 361737110180301 & Forest Lake NTUA 1 & $4 \mathrm{~T}-523$ \\
\hline 361832109462701 & Rough Rock & $10 \mathrm{~T}-258$ \\
\hline 362043110030501 & Kits'illi NTUA 2 & --- \\
\hline
\end{tabular}

\begin{tabular}{c}
$\begin{array}{c}\text { U.S. Geological Survey } \\
\text { identification No. }\end{array}$ Common name or location $\begin{array}{c}\text { Bureau of } \\
\text { Indian Affairs } \\
\text { site No. }\end{array}$ \\
\hline
\end{tabular}

$362149109463301 \quad$ Rough Rock 10R-111

$363005110250901 \quad$ Peabody 2

$362406110563201 \quad$ White Mesa Arch 1K-214

362418109514601

362456110503001

363007110221201

362823109463101

362936109564101

363013109584901

363103109445201

363137110044702

363143110355001

363213110342001

363232109465601

363309110420501

363423110305501

363558110392501

363727110274501

363850110100801

364226110171701

364248109514601

364338110154601

364344110151201

364034110240001

365045109504001
Rough Rock PM5

Cow Springs

Peabody 6

Rough Rock

BM observation well $1 \quad$ 8T-537

Sweetwater Mesa 8K-443

Rough Rock 9Y-95

Chilchinbito PM3 ---

BM observation well $4 \quad$ 2T-514

Shonto Southeast 2K-301

Shonto 2K-300

Shonto Southeast 2T-502

Shonto PM2

Long House Valley 8T-510

BM observation well $2 \quad$ 8T-538

Kayenta West

Northeast Rough Rock $\quad 8$ A-180

BM observation well $3 \quad 8 \mathrm{~T}-500$

Kayenta PM2 8A-295

Marsh Pass 8T-522

Dennehotso PM2

$---$
Rough Rock 9Y-92 


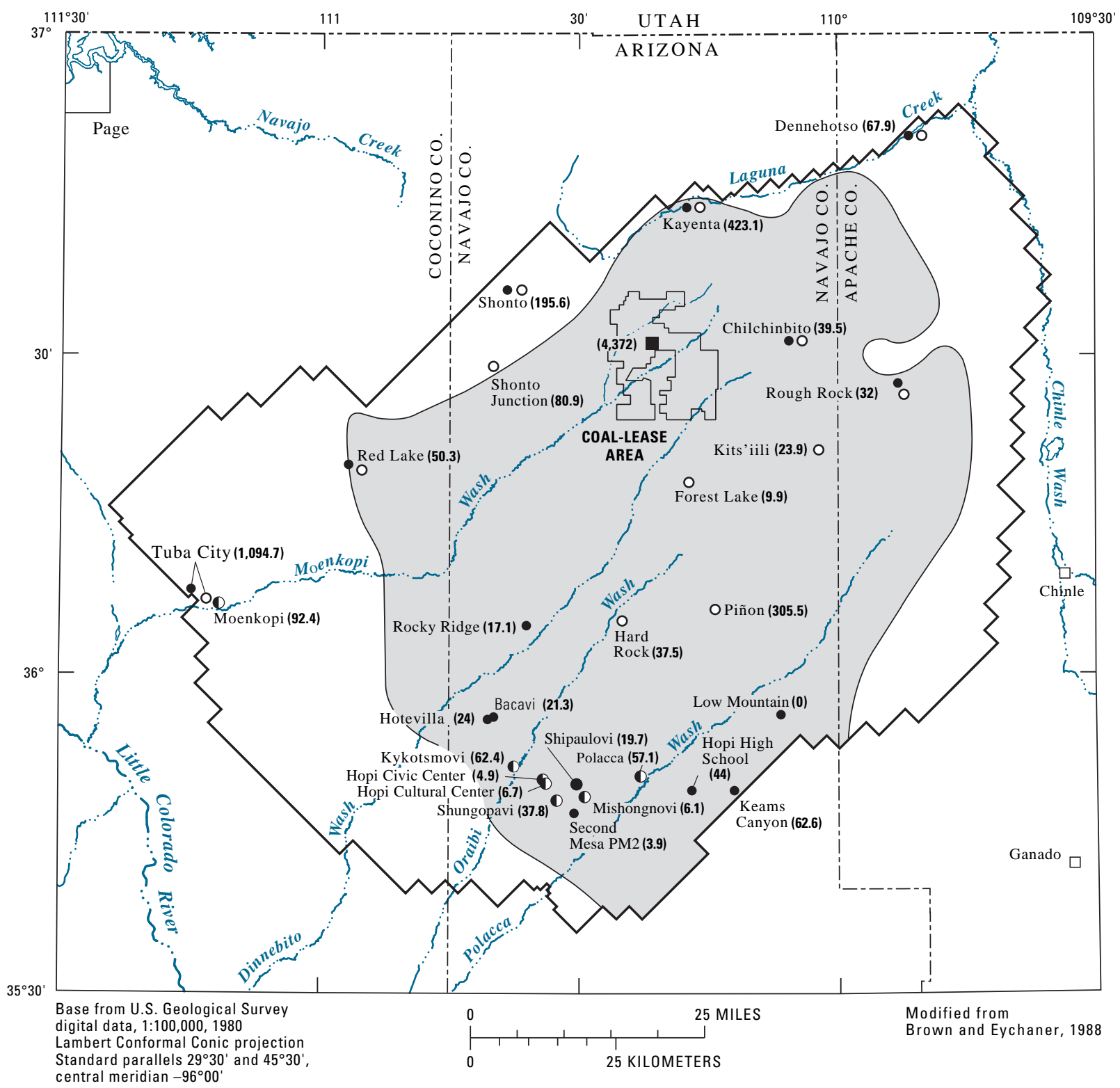

EXPLANATION

CONFINED AND UNCONFINED
CONDITIONS IN THE N AQUIFER
WITHIN MODEL BOUNDARY

Figure 4. Locations of well systems monitored for withdrawals from the N aquifer, Black Mesa area, Arizona, 2004. 
Table 3. Withdrawals from the $\mathrm{N}$ aquifer by well system, Black Mesa area, Arizona, 2004.

[Withdrawals, in acre-feet, are from flowmeter measurements. BIA, Bureau of Indian Affairs; NTUA, Navajo Tribal Utility Authority; USGS, U.S. Geological Survey; Peabody, Peabody Western Coal Company; Hopi, Hopi Village Administrations]

\begin{tabular}{|c|c|c|c|c|}
\hline \multirow{2}{*}{$\begin{array}{c}\text { Well system } \\
\text { (one or more wells) }\end{array}$} & \multirow[b]{2}{*}{ Owner } & \multirow{2}{*}{$\begin{array}{l}\text { Source } \\
\text { of data }\end{array}$} & \multicolumn{2}{|c|}{ Withdrawals } \\
\hline & & & $\begin{array}{l}\text { Confined } \\
\text { aquifer }\end{array}$ & $\begin{array}{l}\text { Unconfined } \\
\text { aquifer }\end{array}$ \\
\hline Chilchinbito & BIA & USGS/BIA & 2.3 & \\
\hline Dennehotso & BIA & USGS/BIA & & 22.0 \\
\hline Hopi High School & BIA & USGS/BIA & 44.0 & \\
\hline Hotevilla & BIA & USGS/BIA & 24.0 & \\
\hline Kayenta & BIA & USGS/BIA & 47.0 & \\
\hline Keams Canyon & BIA & USGS/BIA & 62.6 & \\
\hline Low Mountain & BIA & USGS/BIA & ${ }^{1} 0$ & \\
\hline Piñon & BIA & USGS/BIA & ${ }^{1} 0$ & \\
\hline Red Lake & BIA & USGS/BIA & & 7.0 \\
\hline Rocky Ridge & BIA & USGS/BIA & 17.1 & \\
\hline Rough Rock & BIA & USGS/BIA & 24.6 & \\
\hline Second Mesa & BIA & USGS/BIA & 3.9 & \\
\hline Shonto & BIA & USGS/BIA & & 179.6 \\
\hline Tuba City & BIA & USGS/BIA & & 133.8 \\
\hline Chilchinbito & NTUA & USGS/NTUA & 37.2 & \\
\hline Dennehotso & NTUA & USGS/NTUA & & 45.9 \\
\hline Forest Lake & NTUA & USGS/NTUA & 9.9 & \\
\hline Hard Rock & NTUA & USGS/NTUA & 37.5 & \\
\hline Kayenta & NTUA & USGS/NTUA & 376.1 & \\
\hline Kits'iili & NTUA & USGS/NTUA & 23.9 & \\
\hline Piñon & NTUA & USGS/NTUA & 305.5 & \\
\hline Red Lake & NTUA & USGS/NTUA & & 43.3 \\
\hline Rough Rock & NTUA & USGS/NTUA & 7.4 & \\
\hline Shonto & NTUA & USGS/NTUA & & 16.0 \\
\hline Shonto Junction & NTUA & USGS/NTUA & & 80.9 \\
\hline Tuba City & NTUA & USGS/NTUA & & 960.9 \\
\hline Mine Well Field & Peabody & Peabody & ${ }^{2} 4,372$ & \\
\hline Bacavi & Hopi & USGS/Hopi & 21.3 & \\
\hline Hopi Civic Center & Hopi & USGS/Hopi & 4.9 & \\
\hline Hopi Cultural Center & Hopi & USGS/Hopi & 6.7 & \\
\hline Kykotsmovi & Hopi & USGS/Hopi & 62.4 & \\
\hline Mishongnovi & Hopi & USGS/Hopi & 6.1 & \\
\hline Moenkopi & Hopi & USGS/Hopi & & 92.4 \\
\hline Polacca & Hopi & USGS/Hopi & ${ }^{3} 57.1$ & \\
\hline Shipaulovi & Hopi & USGS/Hopi & 19.7 & \\
\hline Shungopovi & Hopi & USGS/Hopi & 37.8 & \\
\hline
\end{tabular}

\section{${ }^{1}$ Well taken out of service.}

${ }^{2}$ Industrial pumpage.

${ }^{3}$ Estimated. Well PM4 not metered. Annual pumpage from PM4 was estimated as 40 acre-ft on the basis of previous metered data and a per capita consumption of 40 gallons per day. Pumping from the remaining wells (PM5 and PM6) may include some water from the D aquifer.
In 2004, the total ground-water withdrawal from the $\mathrm{N}$ aquifer was about 7,210 acre-ft (table 1), which is less than a 1-percent decrease from the total withdrawal in 2003. Withdrawals for municipal use from the confined area totaled 1,240 acre-ft, which is about an 8-percent decrease from 2003. Withdrawals for municipal use from the unconfined areas totaled 1,600 acre-ft, which is about an 11-percent increase from 2003. Withdrawals for industrial use totaled 4,370 acre$\mathrm{ft}$, which is a 2-percent decrease from 2003, and withdrawals for municipal use totaled 2,840 acre-ft, which is a 2-percent increase from 2003.

Withdrawals from the $\mathrm{N}$ aquifer have been increasing since the 1970s; however, the percentages of withdrawals for industrial and municipal uses have varied during this time (tables 1 and 4, fig. 3). For 1965-2004, industrial withdrawals were 63 percent of the total withdrawals and municipal withdrawals were 37 percent. From 1965 to 1972 , total withdrawals increased from 70 to 8,760 acre-ft, industrial withdrawals were 74 percent of total withdrawals, and municipal withdrawals were 28 percent of total withdrawals. From 1973 to 1984, total withdrawals were 66,470 acre-ft, industrial withdrawals were 70 percent of total withdrawals, and municipal withdrawals were 30 percent of total withdrawals. In 1985, total withdrawals were 4,720 acre-ft, industrial withdrawals were 53 percent of total withdrawals, and municipal withdrawals were 47 percent of total withdrawals. From 1986 to 2003, total withdrawals were 123,640 acre-ft, industrial withdrawals were 60 percent of total withdrawals, and municipal withdrawals were 40 percent of total withdrawals. In 2004, total withdrawals were 7,210 acre-ft, industrial withdrawals were 61 percent of total withdrawals, and municipal withdrawals were 39 percent of total withdrawals.

Table 4. Withdrawals from the $\mathrm{N}$ aquifer by water-use category for 1965-2004 and for other periods, Black Mesa, Arizona.

\begin{tabular}{lccccc}
\hline Period & $\begin{array}{c}\text { Total } \\
\text { withdrawals } \\
\text { (acre-feet) }\end{array}$ & $\begin{array}{c}\text { Industrial } \\
\text { withdrawals } \\
\text { (acre-feet) }\end{array}$ & $\begin{array}{c}\text { Municipal } \\
\text { withdrawals } \\
\text { (acre-feet) }\end{array}$ & $\begin{array}{c}\text { Percent } \\
\text { industrial }\end{array}$ & $\begin{array}{c}\text { Percent } \\
\text { municipal }\end{array}$ \\
\hline $1965-2004$ & 210,970 & 133,620 & 77,350 & 63 & 37 \\
$1965-1972$ & 8,930 & 6,460 & 2,470 & 74 & 28 \\
$1973-1984$ & 66,470 & 46,540 & 19,930 & 70 & 30 \\
1985 & 4,720 & 2,520 & 2,200 & 53 & 47 \\
$1986-2003$ & 123,640 & 73,730 & 49,910 & 60 & 40 \\
2004 & 7,210 & 4,370 & 2,840 & 61 & 39 \\
\hline
\end{tabular}




\section{Ground-Water Levels in the N Aquifer}

Ground water in the $\mathrm{N}$ aquifer is under confined conditions in the central part of the study area and under unconfined or water-table conditions around the periphery (fig. 5). The ground water generally moves radially from the recharge areas near Shonto to the southwest towards Tuba City, to the south towards the Hopi Reservation, and to the east towards Rough Rock and Dennehotso (Eychaner, 1983).

Ground-water levels are measured once a year and compared with levels from previous years to determine changes over time. Only water levels from municipal and stock wells that were not considered recently pumped, influenced by nearby pumping, or blocked or obstructed were used for comparison. During February to April 2005, water levels in 33 of the 34 wells that are used for annual measurements met these criteria (table 5). Six of the 33 wells are the continuousrecording observation wells, and water levels were measured manually in these wells 4 times between June 2004 and June 2005. Twenty-five of the 33 water levels measured in 2005 were compared with water levels for the same wells measured in 2004. Water levels in the remaining 8 wells could not be compared because of obstructions, effects of pumping, or other conditions that prevented an accurate water level to be measured in 2004 and (or) 2005.

The wells used for water-level measurements are distributed throughout the study area (fig. 5). All but one of the wells are completed in the $\mathrm{N}$ aquifer; however, the characteristics of the wells vary considerably. Well $6 \mathrm{H}-55$ was previously thought to be completed in the $\mathrm{N}$ aquifer but is actually completed in the $\mathrm{D}$ aquifer. Construction dates range from 1934 to 1993, depths range from $107 \mathrm{ft}$ near Dennehotso, Arizona, to 3,636 ft near PWCC, and depths to the top of the $\mathrm{N}$ aquifer range from 0 near Tuba City, Arizona, to 2,205 ft near Forest Lake, Arizona (table 6).

From 2004 to 2005, water levels declined in 14 of the 25 wells for which comparisons could be made (table 5). The median water-level change in the 25 wells was $-0.4 \mathrm{ft}$ (table 7). From 2004 to 2005, water levels declined in 6 of the 13 wells in the unconfined areas of the $\mathrm{N}$ aquifer. The median water-level change was $-0.1 \mathrm{ft}$. Water-level changes in the unconfined areas ranged from $-2.8 \mathrm{ft}$ at Tuba City NTUA 1 to $29.3 \mathrm{ft}$ at 9 Y-95 in Rough Rock. In the confined area, water levels declined in 8 of 12 wells from 2004 to 2005 . The median water-level change was $-1.2 \mathrm{ft}$. Water-level changes in the confined area ranged from $-4.9 \mathrm{ft}$ at Kits'iili NTUA 2 to $11.8 \mathrm{ft}$ at Keams Canyon PM2 (tables 5 and 7).

Annual median water-level changes for the water-level network wells from 1983 to 2005 are shown in figure 6 . Annual median changes before 1983 are not shown because there were insufficient water-level data to compute median values. For wells in the confined area, the annual median water-level change was $-1.7 \mathrm{ft}$, and there is no appreciable trend in the annual median water-level changes from 1983 to 2005. For wells in unconfined areas, the annual median waterlevel change was $0.2 \mathrm{ft}$, and there is no appreciable trend in the annual median water-level changes from 1983 to 2005.

From the prestress period (prior to 1965) to 2005, the median water-level change in 33 wells was $-9.0 \mathrm{ft}$ (table 7). Water levels in 16 wells in the unconfined areas had a median change of $-0.6 \mathrm{ft}$. Water-level changes in the unconfined areas ranged from $-33.2 \mathrm{ft}$ at Tuba City NTUA 1 to $+15.0 \mathrm{ft}$ at $9 \mathrm{Y}-$ 95 in Rough Rock (table 5). Water levels in 17 wells in the confined area had a median change of $-32.0 \mathrm{ft}$ (table 7). Waterlevel changes in the confined area ranged from $-193.3 \mathrm{ft}$ at Keams Canyon PM2 to $14.0 \mathrm{ft}$ at $3 \mathrm{~K}-311$ (fig. 5 and table 5).

The areal distribution of water-level changes from the prestress period to 2005 is shown in figure 5. Hydrographs of water levels in the annual well network show the time trends of changes since the 1950s, 1960s, or 1970s (fig. 7). In most of the unconfined areas, water levels have changed only slightly. In the Tuba City area, however, water levels in three wells have declined about $30 \mathrm{ft}$ (fig. 5). Water levels have declined in most of the confined area; however, the magnitudes of declines are varied. Larger declines are near the municipal pumping centers (wells Piñon PM6, Keams Canyon PM2) or near the industrial pumping centers (BM6). Smaller declines occur away from the pumping centers (wells 10T-258, 8K-443, 10R-111, BM4; fig. 5).

Hydrographs for the Black Mesa continuous-record observation wells show continuous water-level since the early 1970s (fig. 8). Water levels in the two wells in the unconfined areas (BM1 and BM4) have had small seasonal or year-to-year variation since 1972. Water levels in wells BM2, BM3, BM5, and BM6 in the confined area have consistently declined since the early to mid-1960s (fig. 8). 


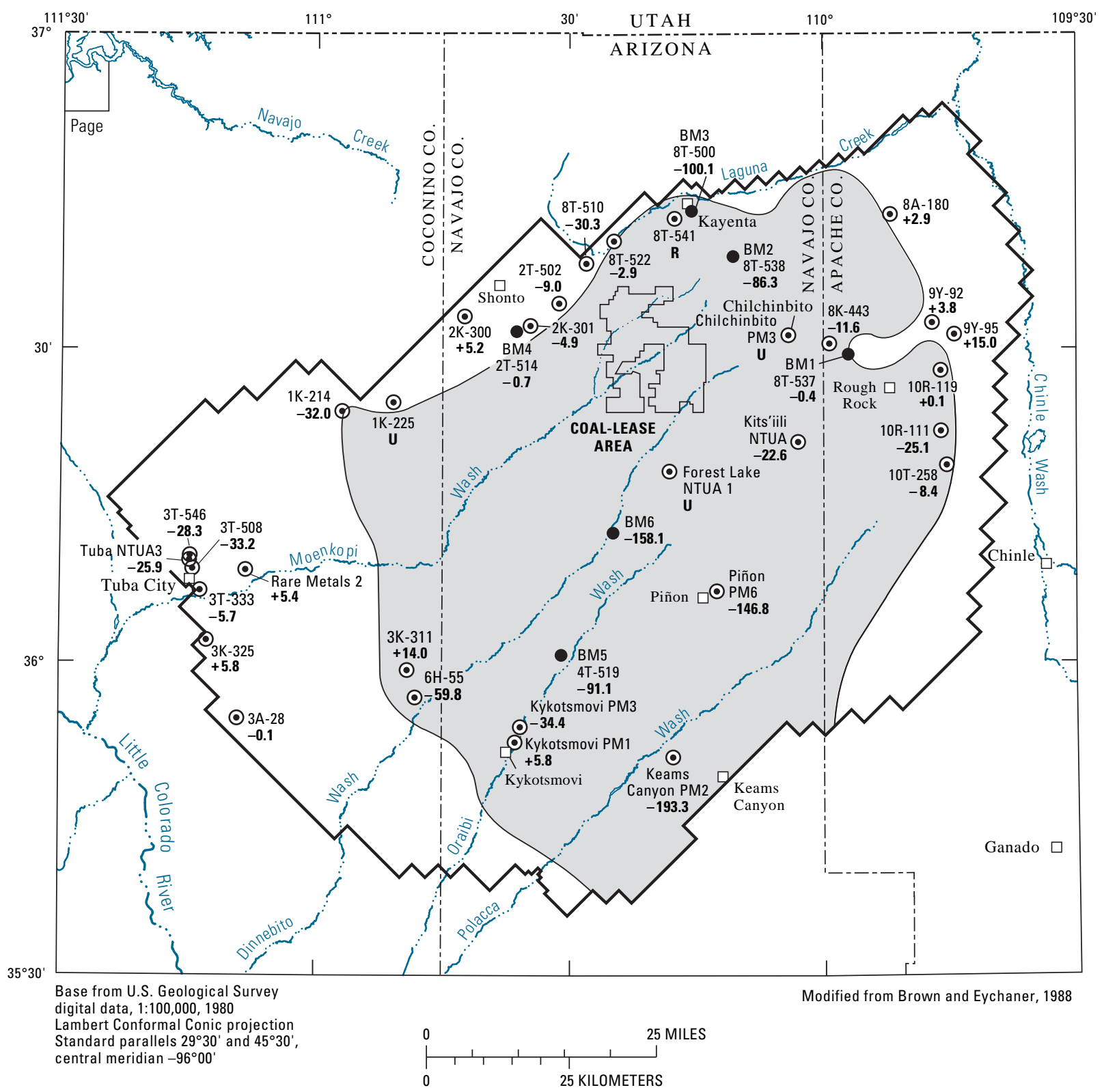

EXPLANATION

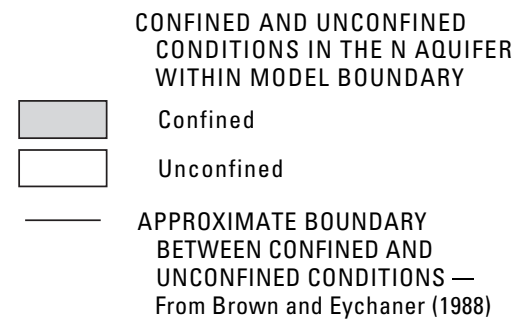

BOUNDARY OF MATHEMATICAL MODEL-From Brown and Eychaner (1988)

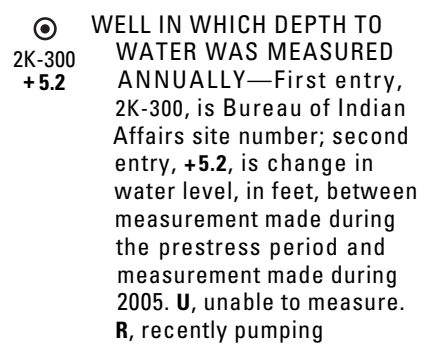

CONTINUOUS WATER-LEVEL RECORDING SITE (OBSERVATION WELL) MAINTAINED BY THE U.S. GEOLOGICAL SURVEY-First entry, BM2, is U.S. Geological Survey well number; second entry, $8 \mathrm{~T}-538$, is Bureau of Indian Affairs site number; third entry, $\mathbf{- 8 6 . 3}$, is change in water level, in feet, from simulated prestress period to 2005

Figure 5. Water-level changes in N aquifer wells from the prestress period to 2005, Black Mesa area, Arizona. 
Table 5. Water-level changes in wells completed in the N aquifer, Black Mesa area, Arizona, prestress period to 2005.

[Dashes indicate no data. R, reported from driller's log]

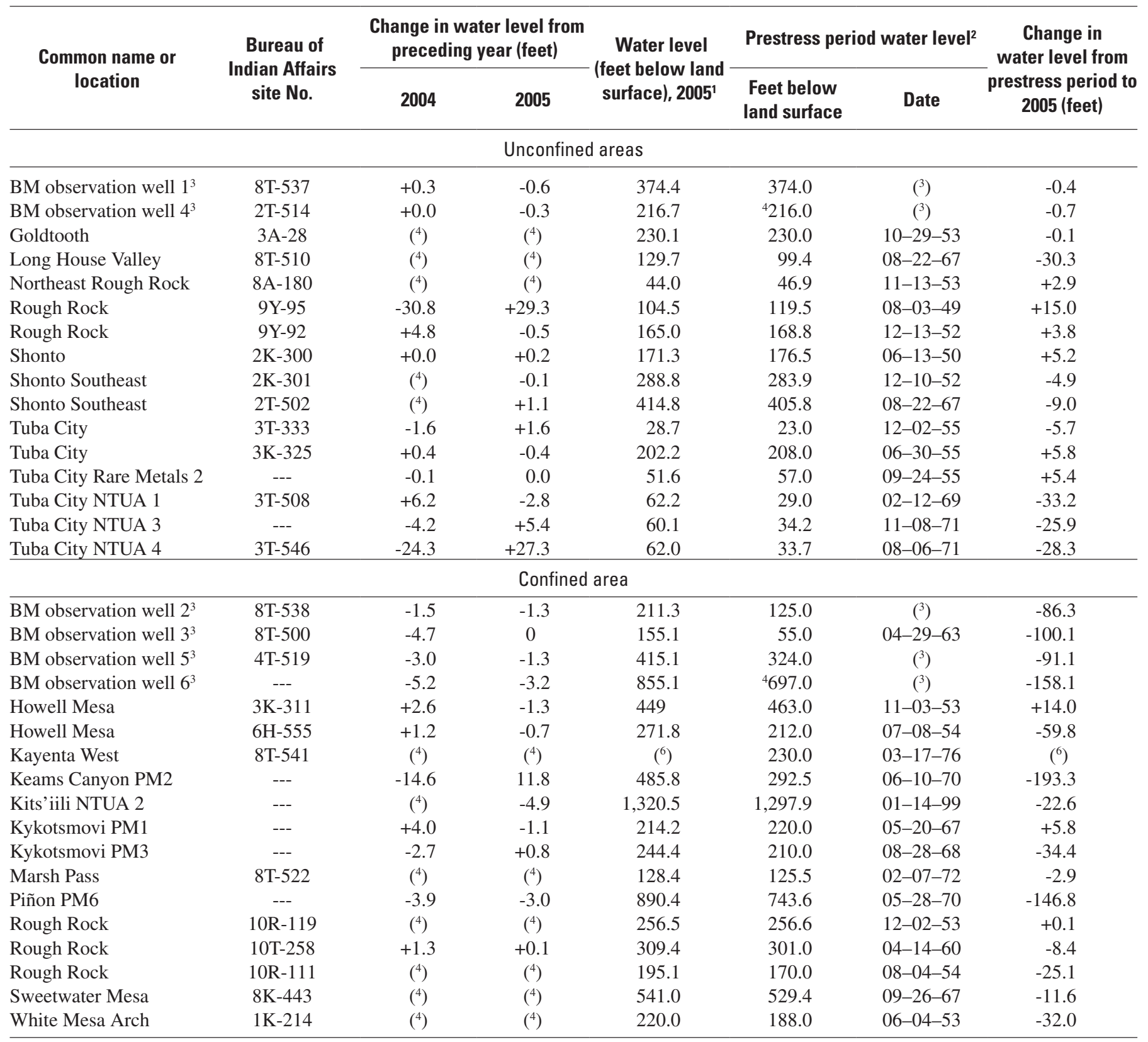

${ }^{1}$ Water level measured during February to April 2005.

${ }^{2}$ Prestress refers to the period of record before appreciable ground-water withdrawals for mining or municipal purposes—about 1965 . For wells that had no water-level measurement before 1965, the earliest water-level measurement is shown.

${ }^{3}$ Continuous recorder. Except for well BM3, prestress water levels were estimated from a ground-water model (Brown and Eychaner, 1988).

${ }^{4} \mathrm{Can}$ not be determined because at least one of the water-level measurements is not available.

${ }^{5} \mathrm{D}$ aquifer well.

${ }^{6} \mathrm{Well}$ recently pumped. 
Table 6. Well-construction characteristics, depth to top of N aquifer, and type of data collected for wells in monitoring program, Black Mesa area, Arizona, 2004-05.

\begin{tabular}{|c|c|c|c|c|c|c|}
\hline $\begin{array}{l}\text { Bureau of Indian Affairs } \\
\text { site No., and (or) } \\
\text { common name }\end{array}$ & $\begin{array}{l}\text { Date well was } \\
\text { completed }\end{array}$ & $\begin{array}{l}\text { Land- } \\
\text { surface } \\
\text { elevation } \\
\text { (feet) }\end{array}$ & $\begin{array}{l}\text { Well depth } \\
\text { (feet below } \\
\text { land surface) }\end{array}$ & $\begin{array}{l}\text { Screened/open } \\
\text { interval(s) } \\
\text { (feet below land } \\
\text { surface) }\end{array}$ & $\begin{array}{l}\text { Depth to top of } \\
\mathrm{N} \text { aquifer } \\
\text { (feet below land } \\
\text { surface }^{1} \text { ) }\end{array}$ & $\begin{array}{c}\text { Type of data } \\
\text { collected }\end{array}$ \\
\hline 8T-537 (BM observation well 1) & $02-01-72$ & 5,864 & 851 & $\begin{array}{l}300-360 \\
400-420 \\
500-520 \\
600-620 \\
730-780\end{array}$ & 290 & Water level \\
\hline 8T-538 (BM observation well 2) & $01-29-72$ & 5,656 & 1,338 & $470-1,338$ & 452 & Water level \\
\hline 8T-500 (BM observation well 3) & $07-29-59$ & 5,724 & 868 & $712-868$ & 155 & Water level \\
\hline 2T-514 (BM observation well 4) & $02-15-72$ & 6,320 & 400 & $250-400$ & 160 & Water level \\
\hline 4T-519 (BM observation well 5) & $02-25-72$ & 5,869 & 1,683 & $1,521-1,683$ & 1,520 & Water level \\
\hline BM observation well 6 & $01-31-77$ & 6,332 & 2,507 & $1,954-2,506$ & 1,950 & Water level \\
\hline $2 \mathrm{~T}-502$ & $08-10-59$ & 6,670 & 523 & $12-523$ & ${ }^{2} 5$ & Water level \\
\hline $3 \mathrm{~A}-28$ & $04-19-35$ & 5,381 & 358 & $\left({ }^{4}\right)$ & 60 & Water level \\
\hline $3 \mathrm{~K}-311$ & ${ }^{3} 11-00-34$ & 5,855 & 745 & $\begin{array}{l}380-395 \\
605-745\end{array}$ & 615 & Water level \\
\hline $3 \mathrm{~K}-325$ & $06-01-55$ & 5,250 & 450 & $75-450$ & ${ }^{2} 30$ & Water level \\
\hline 3T-333 & $12-02-55$ & 4,940 & 229 & $63-229$ & 24 & Water level \\
\hline 3T-508 (Tuba City NTUA 1) & $08-25-59$ & 5,119 & 475 & $\left({ }^{4}\right)$ & 0 & $\begin{array}{l}\text { Water level, } \\
\text { withdrawals }\end{array}$ \\
\hline 3T-546 (Tuba City NTUA 4) & ${ }^{3} 08-00-71$ & 5,206 & 612 & $256-556$ & 0 & $\begin{array}{l}\text { Water level, } \\
\text { withdrawals }\end{array}$ \\
\hline $8 \mathrm{~T}-510$ & $02-11-63$ & 6,262 & 314 & $130-314$ & ${ }^{2} 125$ & Water level \\
\hline $8 \mathrm{~T}-522$ & ${ }^{3} 07-00-63$ & 6,040 & 933 & $180-933$ & 480 & Water level \\
\hline $8 \mathrm{~T}-541$ & $03-17-76$ & 5,885 & 890 & $740-890$ & 700 & Water level \\
\hline 9Y-92 & $01-02-39$ & 5,615 & 300 & $154-300$ & 250 & Water level \\
\hline $9 Y-95$ & $11-05-37$ & 5,633 & 300 & $145-300$ & ${ }^{2} 68$ & Water level \\
\hline 10R-111 & $04-11-35$ & 5,757 & 360 & $267-360$ & 210 & Water level \\
\hline 10R-119 & $01-09-35$ & 5,775 & 360 & $\left({ }^{4}\right)$ & 310 & Water level \\
\hline $10 \mathrm{~T}-258$ & $04-12-60$ & 5,903 & 670 & $465-670$ & 460 & Water level \\
\hline Chilchinbito PM3 & $09-25-65$ & 5,950 & 1,600 & $1,140-1,570$ & 1,136 & Withdrawals \\
\hline Hotevilla PM1 & ${ }^{3} 06-00-57$ & 6,357 & 1,757 & $1,500-1,750$ & 1,450 & $\begin{array}{c}\text { Water chemistry, } \\
\text { withdrawals }\end{array}$ \\
\hline
\end{tabular}


Table 6. Well-construction characteristics, depth to top of N aquifer, and type of data collected for wells in monitoring program, Black Mesa area, Arizona, 2004-05.-Continued

\begin{tabular}{|c|c|c|c|c|c|c|}
\hline $\begin{array}{l}\text { Bureau of Indian Affairs } \\
\text { site No., and (or) } \\
\text { common name }\end{array}$ & $\begin{array}{c}\text { Date well was } \\
\text { completed }\end{array}$ & $\begin{array}{l}\text { Land- } \\
\text { surface } \\
\text { elevation } \\
\text { (feet) }\end{array}$ & $\begin{array}{l}\text { Well depth } \\
\text { (feet below } \\
\text { land surface) }\end{array}$ & $\begin{array}{c}\text { Screened/open } \\
\text { interval(s) } \\
\text { (feet below land } \\
\text { surface) }\end{array}$ & $\begin{array}{l}\text { Depth to top of } \\
\mathrm{N} \text { aquifer } \\
\text { (feet below land } \\
\text { surface }\end{array}$ & $\begin{array}{c}\text { Type of data } \\
\text { collected }\end{array}$ \\
\hline Keams Canyon PM2 & ${ }^{3} 05-00-70$ & 5,809 & 1,106 & $906-1,106$ & 900 & $\begin{array}{l}\text { Water level, } \\
\text { withdrawals, } \\
\text { water chemistry }\end{array}$ \\
\hline Kykotsmovi PM1 & $02-20-67$ & 5,657 & 995 & $\begin{array}{l}655-675 \\
890-990\end{array}$ & 880 & $\begin{array}{l}\text { Water level, } \\
\text { withdrawals }\end{array}$ \\
\hline Low Mountain PM2 & ${ }^{3} 04-00-72$ & 6,123 & 1,343 & $1,181-1,262$ & 1,153 & Water level \\
\hline Peabody 2 & ${ }^{3} 06-00-67$ & 6,530 & 3,636 & $1,816-3,603$ & 728 & $\begin{array}{l}\text { Water chemistry, } \\
\text { withdrawals }\end{array}$ \\
\hline Peabody 6 & $06-00-65$ & 6,645 & 3,559 & $2,047-3,494$ & 894 & $\begin{array}{l}\text { Water chemistry, } \\
\text { withdrawals }\end{array}$ \\
\hline Piñon NTUA 1 & $02-25-80$ & 6,336 & 2,350 & $1,860-2,350$ & 1,850 & $\begin{array}{c}\text { Water chemistry, } \\
\text { withdrawals }\end{array}$ \\
\hline Piñon PM6 & ${ }^{3} 02-00-70$ & 6,397 & 2,248 & $1,895-2,243$ & 1,870 & $\begin{array}{l}\text { Water level, } \\
\text { withdrawals }\end{array}$ \\
\hline Rocky Ridge PM2 & $06-26-63$ & 5,985 & 1,780 & $1,480-1,780$ & 1,442 & Water level \\
\hline Tuba City Rare Metals 2 & ${ }^{3} 09-00-55$ & 5,108 & 705 & $100-705$ & 255 & Water level \\
\hline
\end{tabular}

${ }^{1}$ Depth to top of N aquifer from Eychaner (1983) and Brown and Eychaner (1988).

${ }^{2}$ All material between land surface and top of the $\mathrm{N}$ aquifer is unconsolidated—soil, alluvium, or dune sand.

${ }^{3} 00$, indicates month or day is unknown.

${ }^{4}$ Screened and (or) open intervals are unknown.

${ }^{5}$ Depth to top of $\mathrm{N}$ aquifer was not estimated.

${ }^{6}$ Developed into the $\mathrm{D}$ aquifer. 
Table 7. Median changes in water levels, 2004-05 and prestress period to 2005, Black Mesa area, Arizona.

\begin{tabular}{llcc}
\hline \multicolumn{1}{c}{ Years } & $\begin{array}{c}\text { Aquifer } \\
\text { conditions }\end{array}$ & $\begin{array}{c}\text { Number of } \\
\text { wells }\end{array}$ & $\begin{array}{c}\text { Median change in } \\
\text { water level (feet) }\end{array}$ \\
\hline \multirow{2}{*}{$004-05$} & All & 25 & -0.4 \\
& Unconfined & 13 & -.1 \\
& Confined & 12 & -1.2 \\
Prestress-2005 & All & 33 & -9.0 \\
& Unconfined & 16 & -.6 \\
& Confined & 17 & -32.0 \\
\hline
\end{tabular}

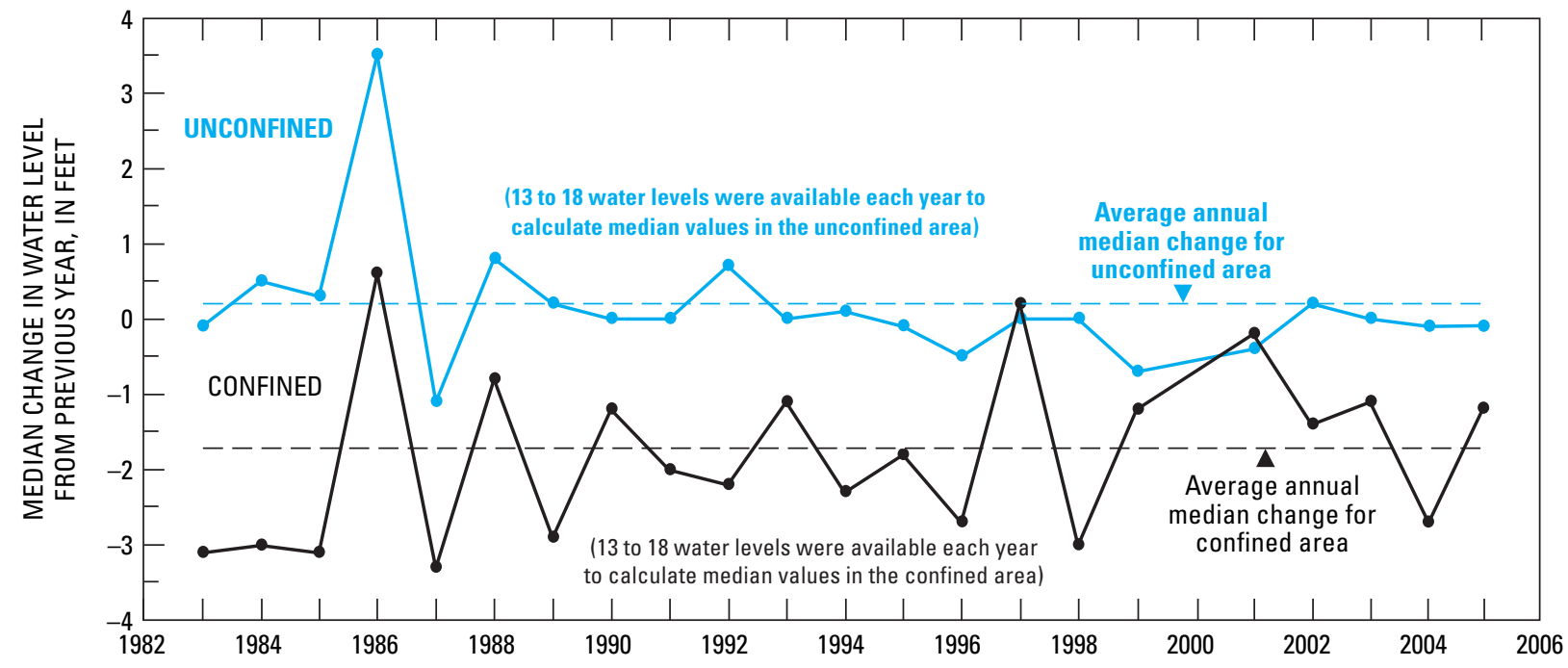

Figure 6. Annual median water-level changes for observation wells completed in the $\mathrm{N}$ aquifer, Black Mesa area, Arizona, 1983-2005. 
UNCONFINED AREA
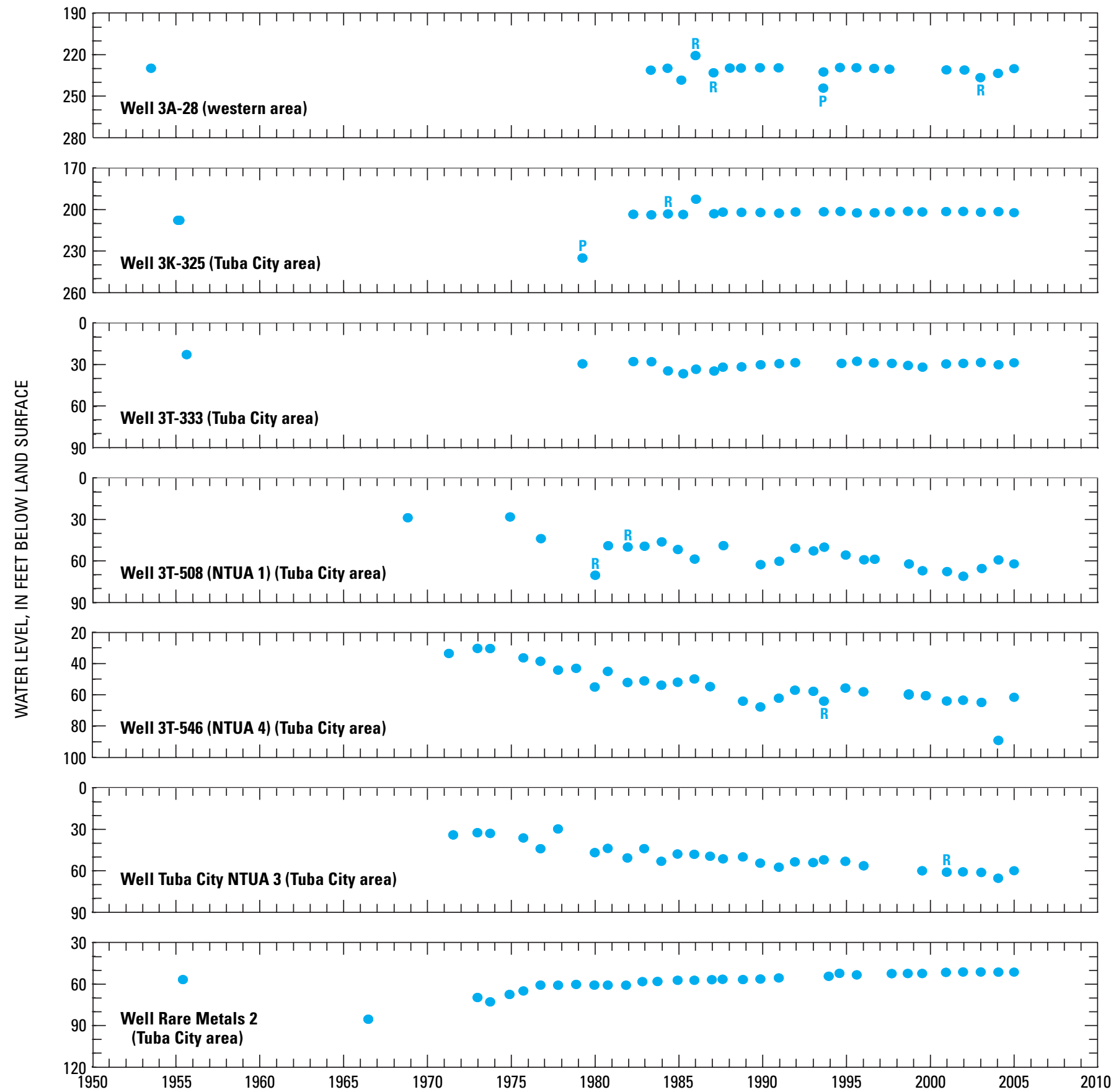

Figure 7. Observed water levels (1950-2005) in annual observation well network, Black Mesa area, Arizona. $P$, pumping; $R$, recently pumping. 
UNCONFINED AREA
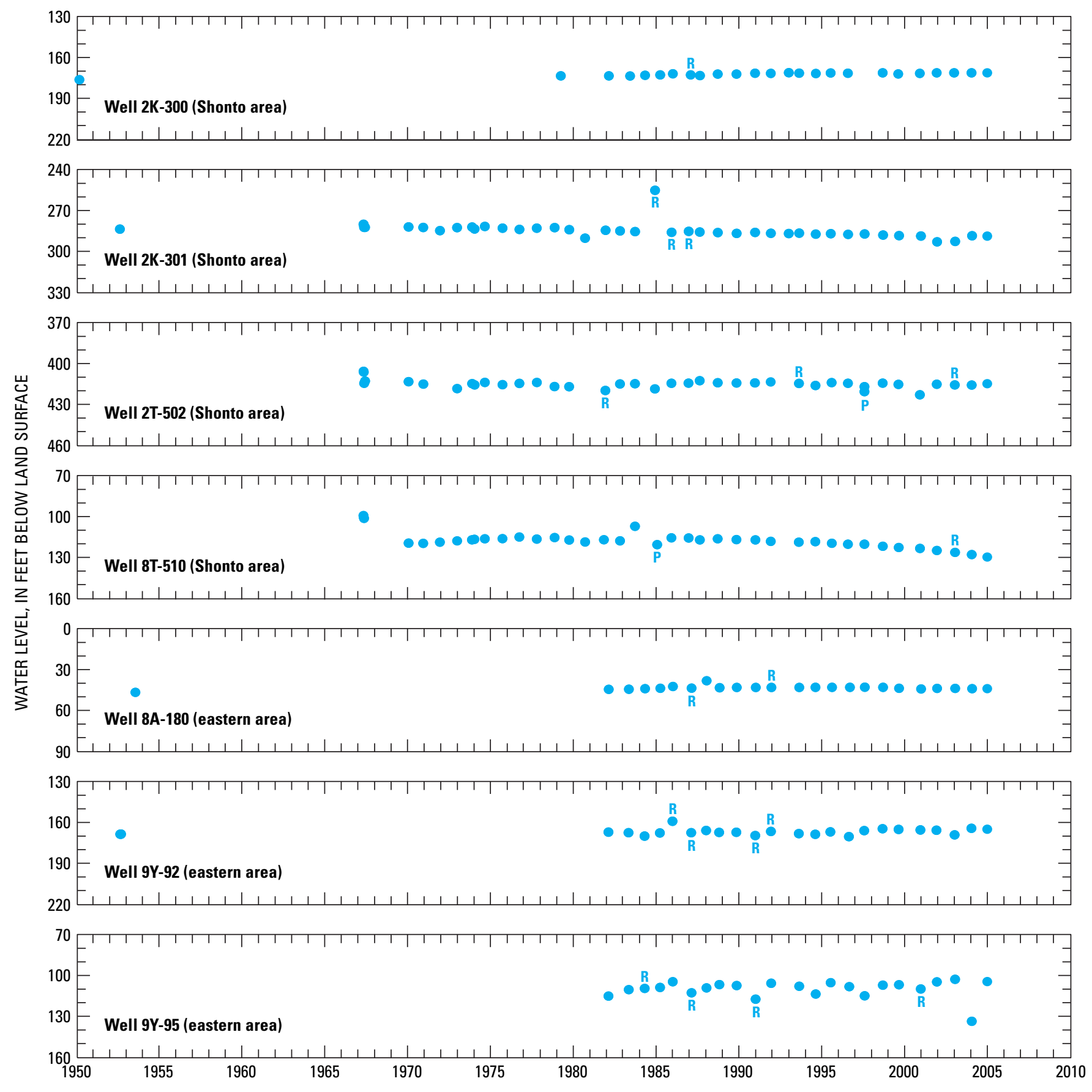

Figure 7. Continued. 
CONFINED AREA
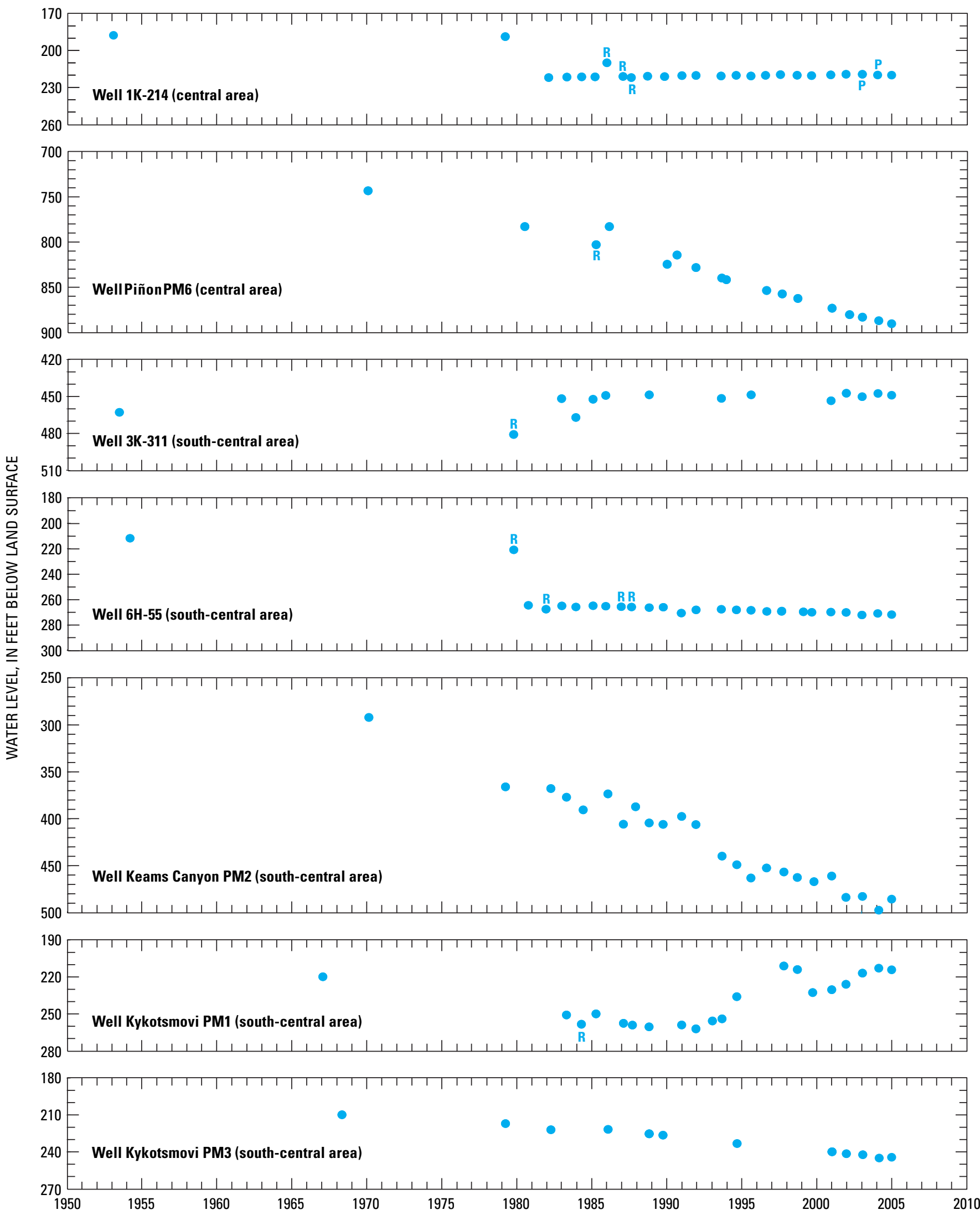

Figure 7. Continued. 
CONFINED AREA

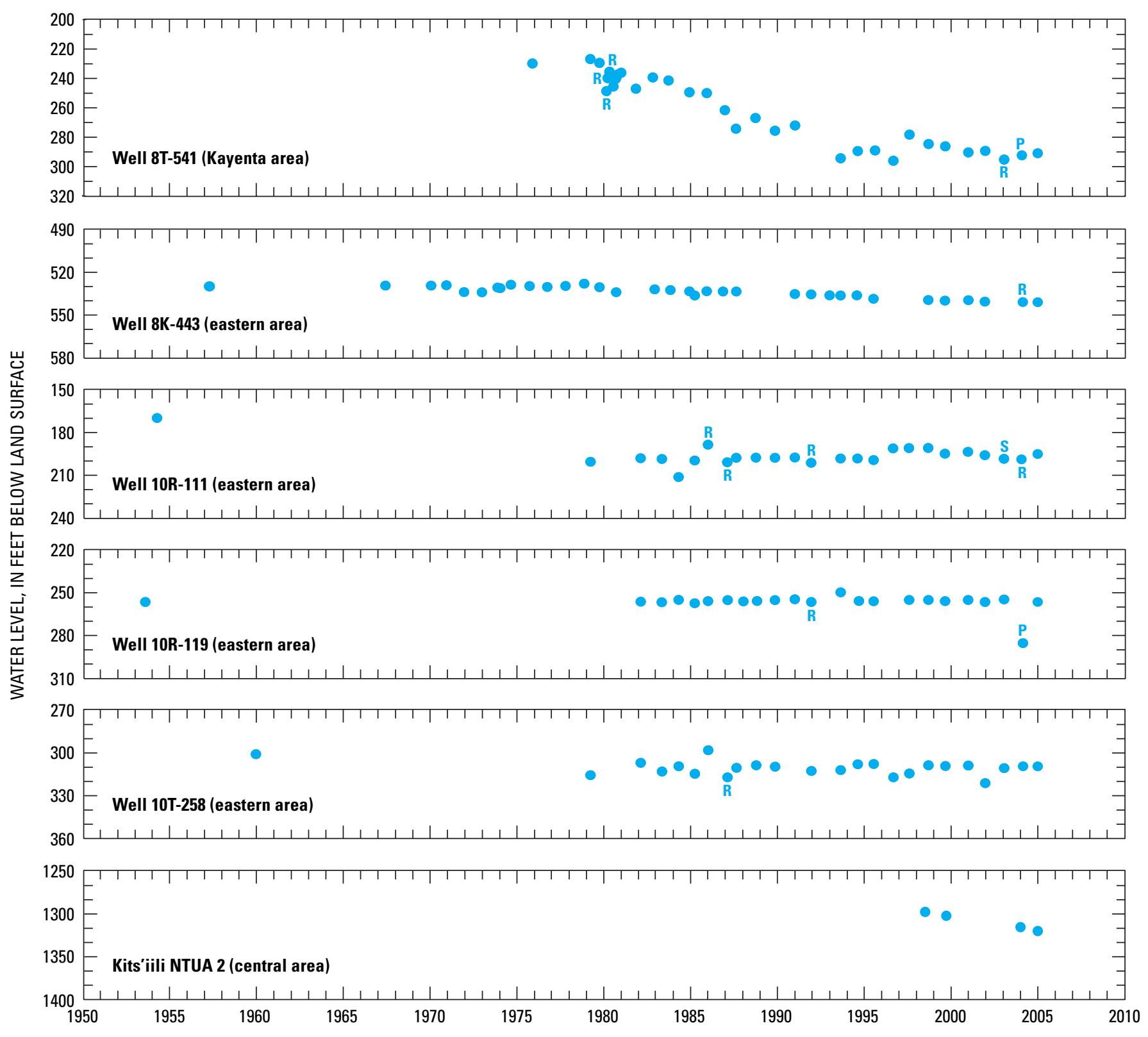

Figure 7. Continued. 


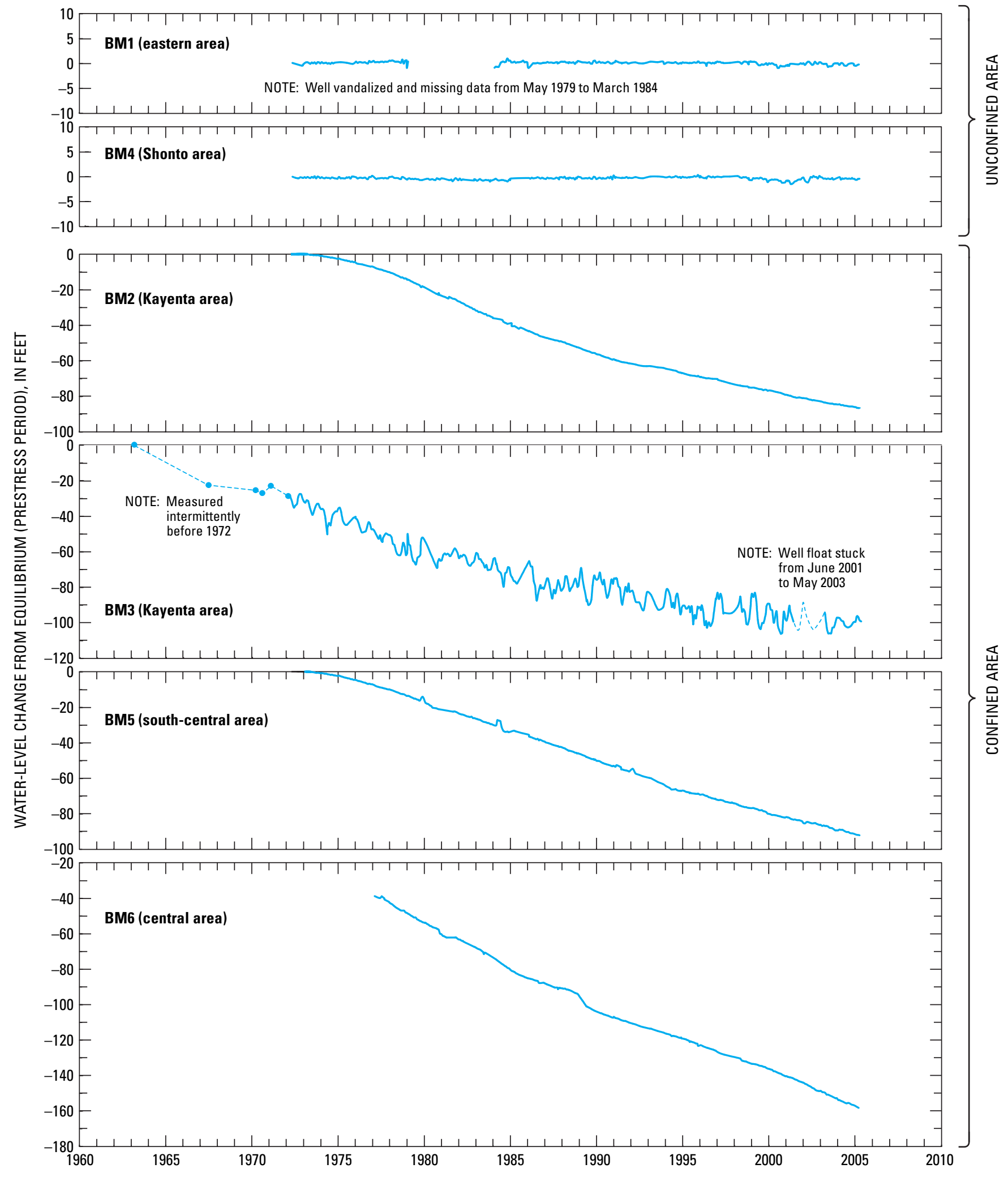

Figure 8. Observed water-level changes in continuous-record observation wells, BM1-BM6, 1963-2005, Black Mesa area, Arizona. 


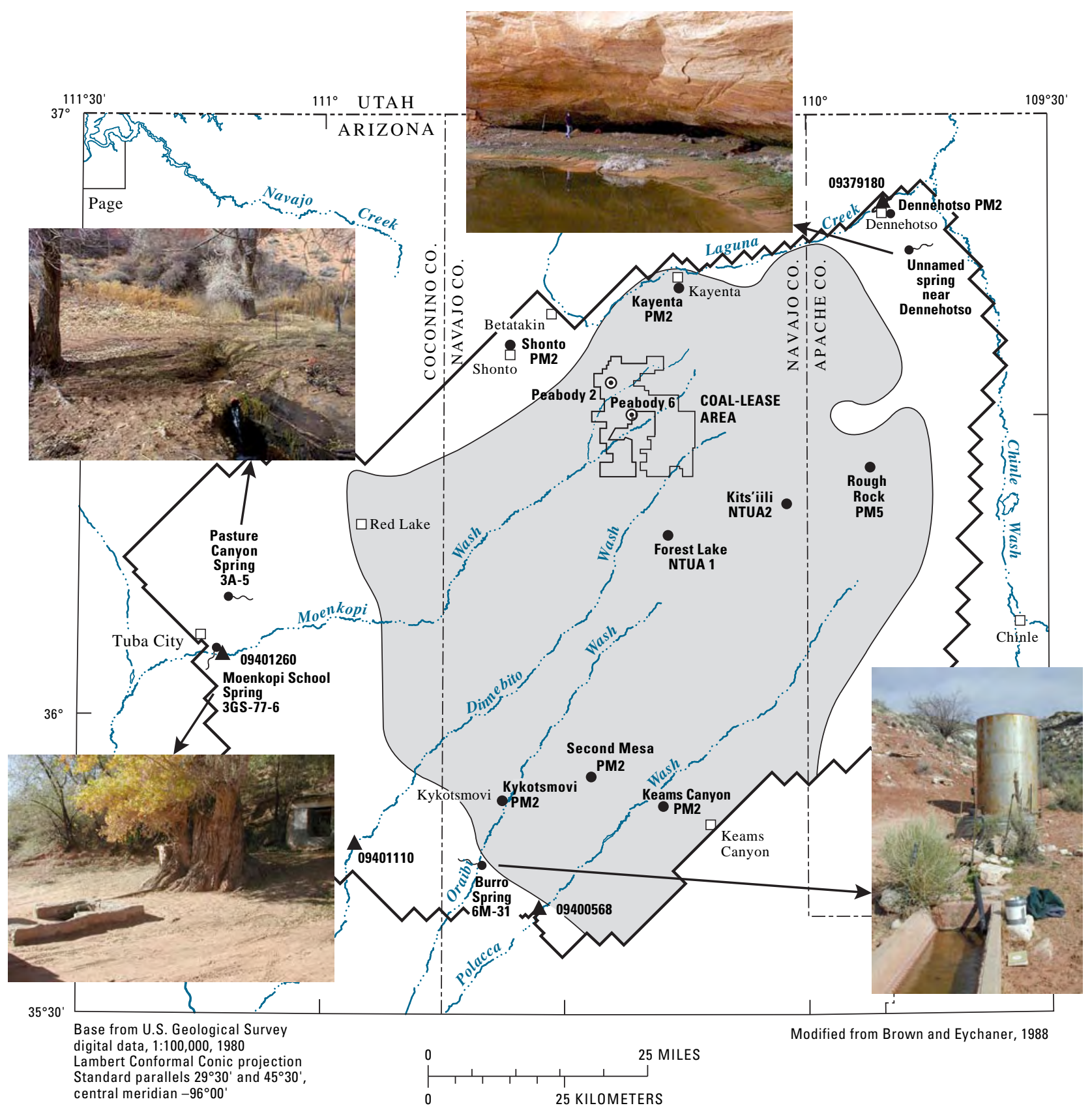

EXPLANATION

CONFINED AND UNCONFINED CONDITIONS IN THE N AQUIFER WITHIN MODEL BOUNDARY

Confined

Unconfined

APPROXIMATE BOUNDARY

BETWEEN CONFINED AND

UNCONFINED CONDITIONS -

From Brown and Eychaner (1988)

BOUNDARY OF MATHEMATICAL MODEL-

From Brown and Eychaner (1988)
MUNICIPAL WELL FROM WHICH WATER-CHEMISTRY SAMPLE WAS COLLECTED-Rough Rock PM5 is well name

$\odot \quad$ INDUSTIAL WELL FROM WHICH Peabody 6 WATER-CHEMISTRY SAMPLE WAS COLLECTED-Peabody 6 is a well number
SPRING AT WHICH DISCHARGE WAS MEASURED AND

Burro

Spring WATER-CHEMISTRY SAMPLE

6M-31 WAS COLLECTED - Number is

spring identification

$\Delta$

STREAMFLOW-GAGING STATION OPERATED BY THE U.S. GEOLOGICAL SURVEY—Number is station identification

Figure 9. Surface-water and water-chemistry data-collection sites, Black Mesa area, Arizona, 2004-05. Photograph of Pasture Canyon Spring has been digitally altered. 


\section{Spring Discharge from the N Aquifer}

Ground water in the $\mathrm{N}$ aquifer discharges from many springs around the margins of Black Mesa, and four of these springs are monitored for discharge. Three springs are in the western or southwestern part of the Black Mesa area, and one is in the northeastern part (fig. 9). Discharges from Moenkopi School Spring, the unnamed spring near Dennehotso, Pasture Canyon Spring, and Burro Spring are measured annually and compared to discharges from previous years to determine changes over time (fig. 10). Discharge was measured in March-April 2005 at the four springs (table 8). Measurements at Burro Spring, Moenkopi School Spring, and Pasture Canyon Spring are made volumetrically, and measurements at the unnamed spring near Dennehotso are made with a flume. The measurements may not reflect the total discharge at each site because some ground water may rise to the land surface downgradient from the measuring point.

In 2005, measured discharges were $0.2 \mathrm{gal} / \mathrm{min}$ from Burro Spring, $11.5 \mathrm{gal} / \mathrm{min}$ from Moenkopi School Spring, $21.5 \mathrm{gal} / \mathrm{min}$ from the unnamed spring near Dennehotso, and $33.3 \mathrm{gal} / \mathrm{min}$ from Pasture Canyon Spring (table 8). From 2004 to 2005, discharge stayed the same at Burro Spring, decreased by 5 percent at Moenkopi School Spring, increased by 71 percent at the unnamed spring near Dennehotso, and increased by 8 percent at Pasture Canyon Spring. For the periods of record at all four springs, the discharges have fluctuated but no increasing or decreasing trends are apparent (fig. 10).

\section{Surface-Water Discharge}

Surface-water discharge in the study area is a measurement of ground-water discharge to streams and direct runoff of rainfall or snowmelt. Ground water discharges to some channel reaches at a fairly constant rate throughout the year; however, the amount of discharge that results in surface flow is affected by seasonal fluctuations in water uptake by plants and in evapotranspiration (Thomas, 2002a). In contrast, the amount of rainfall or snowmelt runoff varies widely throughout the year. In the winter and spring, the amount and timing of snowmelt runoff are a result of the temporal variation in snow accumulation, air temperatures, and rate of snowmelt. Although most rainfall runoff is in the summer, runoff can occur throughout the year. The amount and timing of rainfall runoff depend on the intensity and duration of thunderstorms in the summer and cyclonic storms in the fall, winter, and spring.

Continuous surface-water discharge data have been collected at selected streams each year since the monitoring program began in 1971 to provide information about groundwater discharge and runoff from rainfall and snowmelt. In this study, the total discharge in streams is roughly separated into ground-water discharge and runoff so that the temporal trends in ground-water discharge can be monitored.

In 2004, discharge data were collected at five continuous-recording streamflow-gaging stations (tables 9-13). Data collection at these stations began in July 1976 (Moenkopi Wash, 09401260), July 1996 (Laguna Creek, 09379180), June 1993 (Dinnebito Wash, 09401110), April 1994 (Polacca Wash, 09400568), and August 2004 (Pasture Canyon Spring, 09401256; fig. 9 and table 14).

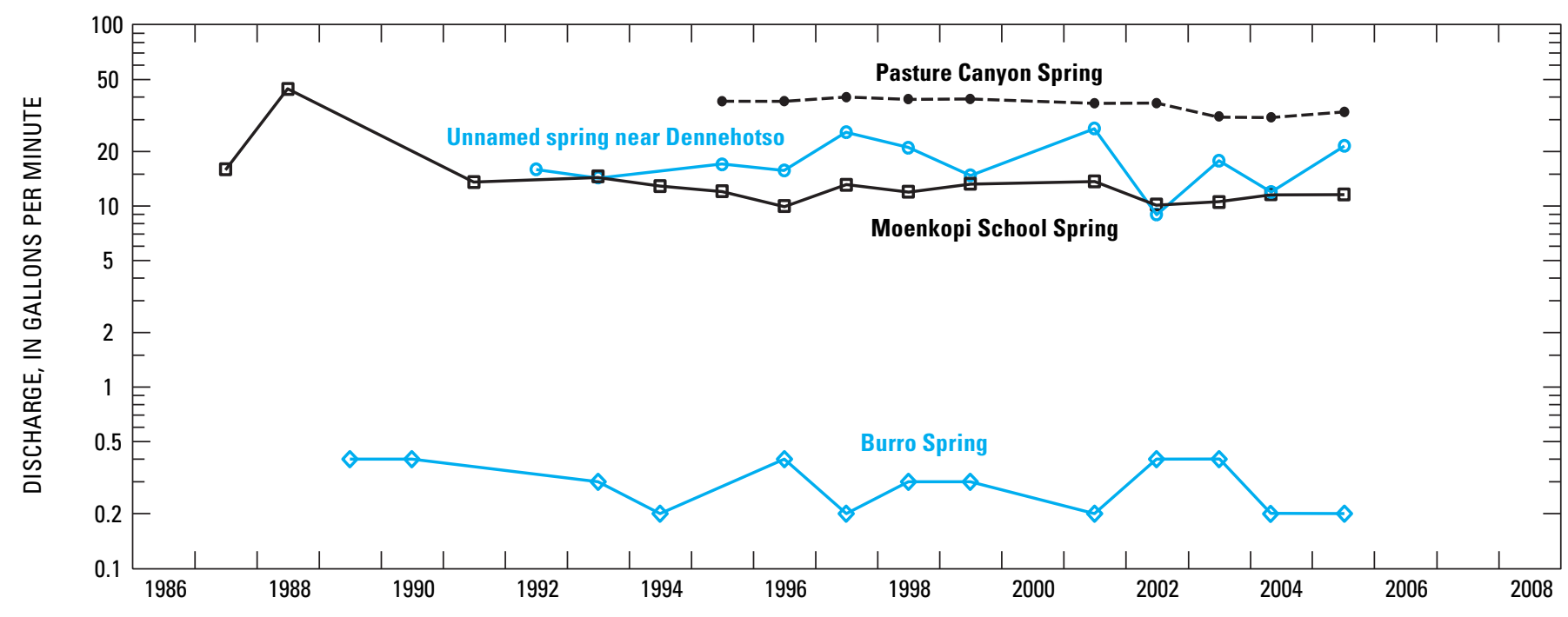

Figure 10. Discharge from selected springs, Black Mesa area, Arizona, 1987-2005. Data from earlier measurements at Moenkopi School Spring, unnamed spring near Dennehotso, and Pasture Canyon Spring are not shown because different measuring locations were used. 
Table 8. Discharge measurements of selected springs, Black Mesa area, Arizona, 1952-2005.

[All the measured discharges do not represent the total discharge from the springs]

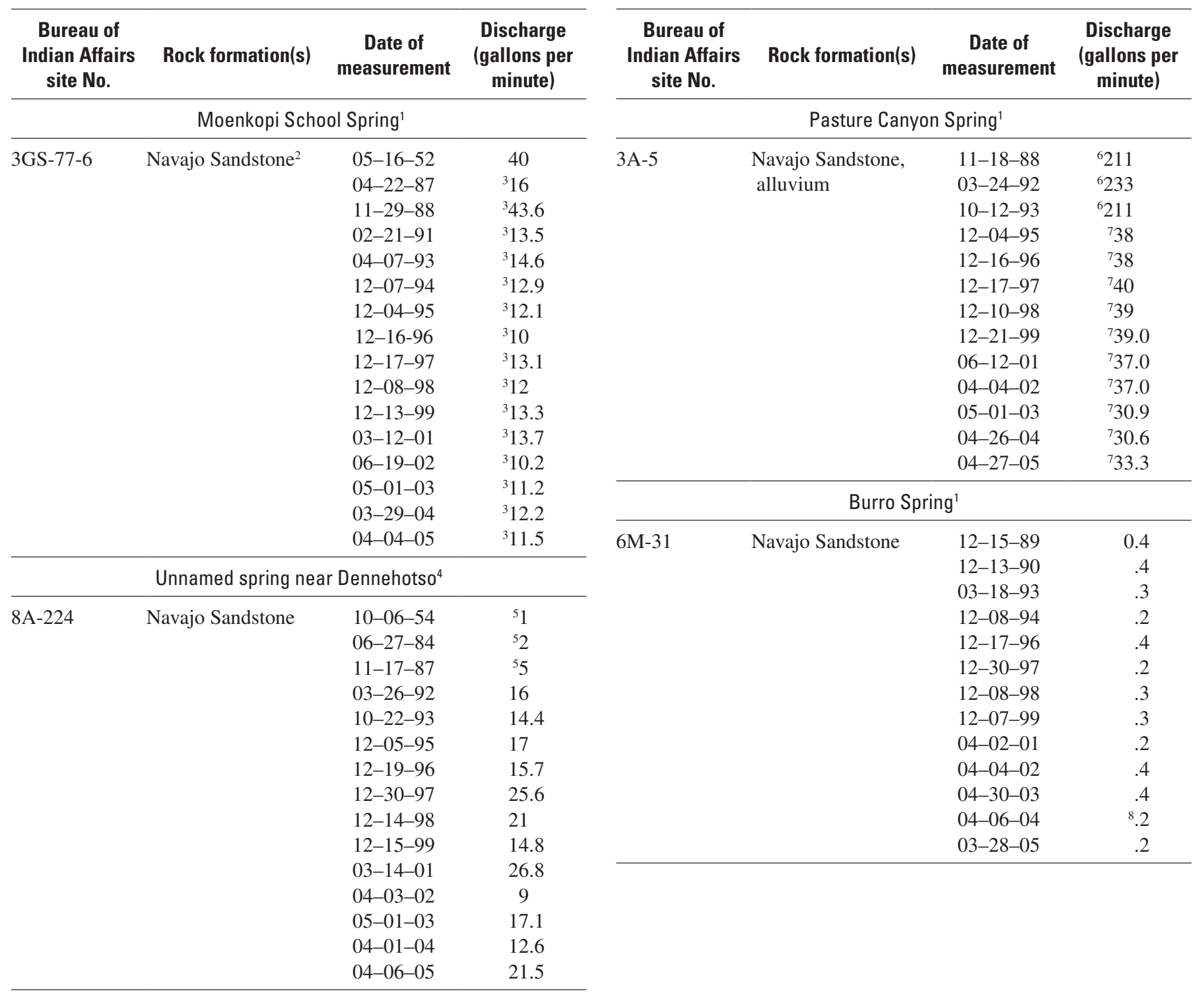

${ }^{1}$ Volumetric discharge measurement.

${ }^{2}$ Tongue in the Kayenta Formation.

${ }^{3}$ Discharge measured at water-quality sampling site and at a different point than the measurement in 1952.

${ }^{4}$ Flume discharge measurement.

${ }^{5}$ Discharge measured at a different point than later measurements.

${ }^{6}$ Discharge measured in an irrigation ditch about 0.25 mile below water-quality sampling point.

${ }^{7}$ Discharge measured at water-quality sampling point about 20 feet below upper spring on west side of canyon.

${ }^{8}$ Discharge is approximate because the container used for the volumetric measurement was not calibrated. 
Table 9. Discharge data, Moenkopi Wash at Moenkopi, Arizona (09401260), calendar year 2004.

[e, estimated. Dashes indicate no data]

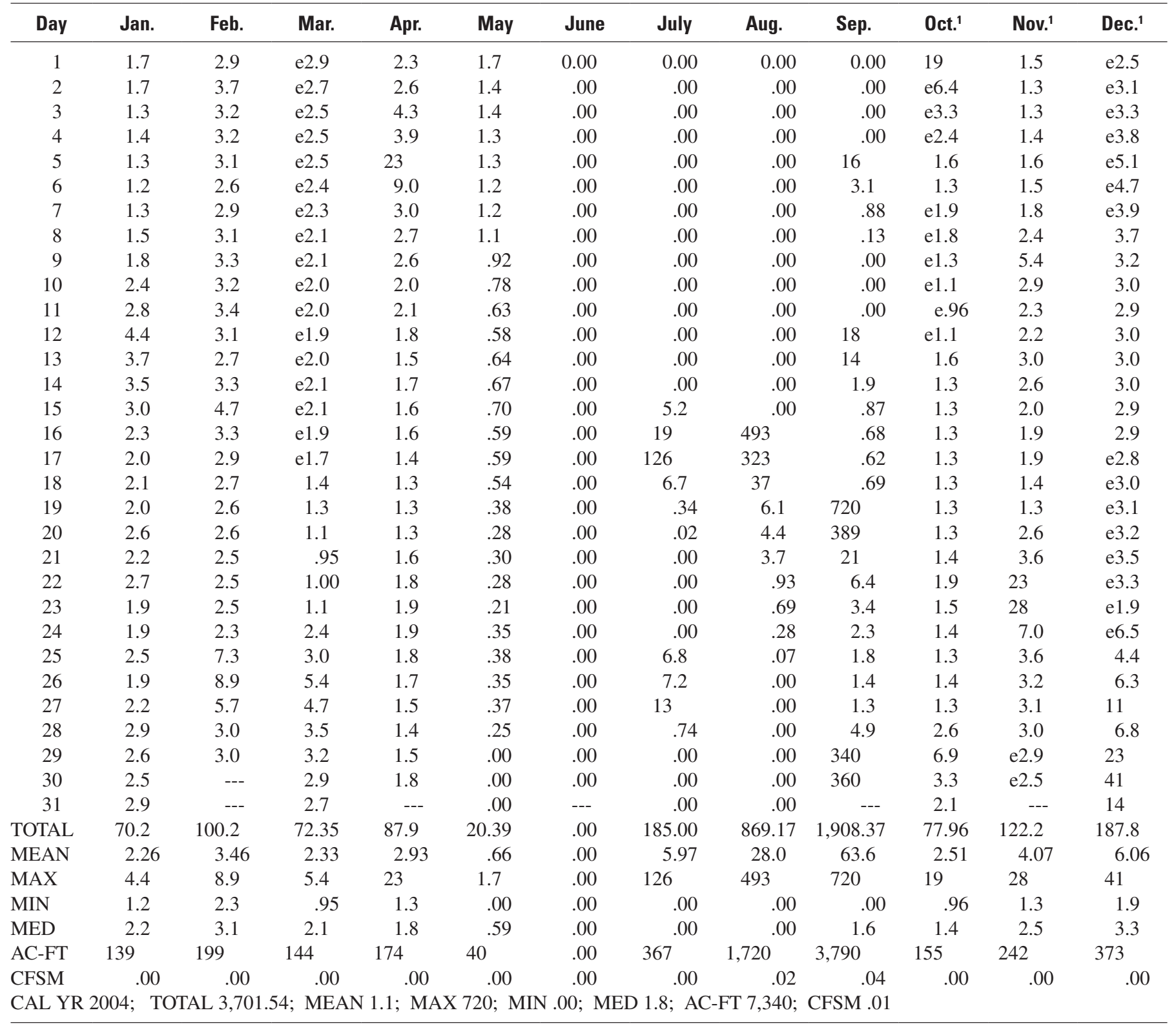

${ }^{1}$ Month in which data are provisional, subject to revision. 
Table 10. Discharge data, Laguna Creek at Dennehotso, Arizona (09379180), calendar year 2004.

[e, estimated. Dashes indicate no data]

\begin{tabular}{|c|c|c|c|c|c|c|c|c|c|c|c|c|}
\hline Day & Jan. & Feb. & Mar. & Apr. & May & June & July & Aug. & Sep. & Oct. ${ }^{1}$ & Nov. ${ }^{1}$ & Dec. $^{1}$ \\
\hline 2 & 1.3 & e1.4 & e3.5 & .00 & .00 & .00 & .00 & .00 & .00 & 2.0 & .12 & .01 \\
\hline 4 & $\mathrm{e} 1.2$ & .70 & e2.8 & 3.5 & .00 & .00 & .00 & .00 & .00 & .06 & .00 & .00 \\
\hline 5 & e. 90 & e1.1 & e3.5 & $\mathrm{e} 2.2$ & .00 & .00 & .00 & .00 & .00 & .00 & .00 & .00 \\
\hline 6 & .27 & .80 & e3.3 & e3.1 & .00 & .00 & .00 & .00 & .00 & .00 & .00 & .00 \\
\hline 9 & .01 & .66 & $\mathrm{e} 1.4$ & e8.7 & .00 & .00 & .00 & e. 50 & .00 & .00 & .57 & .00 \\
\hline 10 & .02 & 1.1 & e. 25 & e3.9 & .00 & .00 & .00 & .00 & .00 & .00 & 1.3 & .00 \\
\hline 11 & .78 & 1.6 & e. 67 & e1.6 & .00 & .00 & .00 & .00 & .00 & .00 & .59 & 12 \\
\hline 12 & .80 & 1.2 & e. 80 & e.96 & .00 & .00 & .00 & .00 & .25 & .00 & .22 & 10 \\
\hline 13 & .32 & e1.0 & e. 67 & e. 71 & .00 & .00 & .00 & .00 & 2.3 & .00 & 12 & 8.7 \\
\hline 18 & .52 & 3.7 & .45 & .00 & .00 & .00 & .14 & 28 & .00 & .00 & 1.2 & 1.3 \\
\hline 19 & 1.1 & 5.6 & .00 & .00 & .00 & .00 & .00 & 2.2 & .00 & .00 & 1.0 & .27 \\
\hline 20 & 3.3 & 6.6 & .00 & .00 & .00 & .00 & .00 & .63 & 106 & .00 & 1.1 & .36 \\
\hline 21 & 2.2 & 6.5 & .00 & .00 & .00 & .00 & .00 & .88 & 25 & .00 & 2.9 & .13 \\
\hline 22 & 1.3 & 7.6 & .00 & .00 & .00 & .00 & .00 & .87 & 5.2 & .00 & 28 & .00 \\
\hline 23 & 2.2 & 8.3 & .00 & .00 & .00 & .00 & .00 & .13 & 2.5 & .00 & 16 & .00 \\
\hline 24 & 1.6 & 9.4 & .00 & .00 & .00 & .00 & .00 & .00 & .77 & .62 & 6.2 & .00 \\
\hline 25 & .73 & 13 & .00 & 13 & .00 & .00 & .00 & .00 & .11 & .35 & 4.3 & .00 \\
\hline 26 & 1.0 & e11 & .00 & 2.0 & .00 & .00 & 6.7 & .00 & .00 & .29 & 5.0 & .00 \\
\hline 27 & e1.9 & e7.5 & .00 & .77 & .00 & .00 & 14 & .00 & .00 & .27 & 4.0 & .00 \\
\hline 28 & e1.9 & e5.0 & .00 & .01 & .00 & .00 & e 4.0 & .00 & .00 & .36 & 4.1 & .25 \\
\hline AC-FT & 66 & 219 & 63 & 161 & .00 & .00 & 51 & 175 & 532 & 55 & 202 & 223 \\
\hline CFSM & .00 & .01 & .00 & .01 & .00 & .00 & .00 & .01 & .02 & .00 & .01 & .01 \\
\hline
\end{tabular}

${ }^{1}$ Month in which data are provisional, subject to revision. 
Table 11. Discharge data, Dinnebito Wash near Sand Springs, Arizona (09401110), calendar year 2004.

[e, estimated. Dashes indicate no data]

\begin{tabular}{|c|c|c|c|c|c|c|c|c|c|c|c|c|}
\hline Day & Jan. & Feb. & Mar. & Apr. & May & June & July & Aug. & Sep. & 0ct. ${ }^{1}$ & Nov. ${ }^{1}$ & Dec. $^{1}$ \\
\hline 2 & .38 & .39 & .37 & .41 & .23 & .13 & 0.72 & .20 & .14 & e3.0 & .36 & .37 \\
\hline 4 & .26 & .50 & .36 & .32 & .21 & .11 & .11 & 6.4 & .23 & e. 40 & .40 & .34 \\
\hline 5 & .26 & .39 & .33 & .42 & .19 & .11 & .11 & 14 & 77 & e. 40 & .40 & .54 \\
\hline 6 & .27 & .41 & .32 & .33 & .18 & .11 & .10 & 2.0 & 9.1 & e. 40 & .41 & .55 \\
\hline 9 & .34 & .41 & .35 & .32 & .19 & .09 & .10 & .10 & .09 & e. 40 & .46 & .51 \\
\hline 10 & .38 & .39 & .37 & .28 & .16 & .09 & .10 & .10 & .09 & e. 40 & .44 & .49 \\
\hline 11 & .37 & .36 & .37 & .27 & .13 & .10 & .10 & .10 & .08 & e. 40 & .44 & .49 \\
\hline 12 & .35 & .31 & .49 & .27 & .15 & .11 & .10 & .09 & .09 & e. 40 & .44 & .49 \\
\hline 13 & .34 & .32 & .38 & .27 & .16 & .10 & .11 & .10 & .09 & e. 40 & .38 & .52 \\
\hline 18 & .35 & .35 & .36 & .23 & .14 & .10 & 25 & 19 & .09 & .37 & .66 & .45 \\
\hline 19 & .37 & .34 & .36 & .25 & .14 & .09 & 69 & 3.8 & e601 & .38 & 1.0 & .44 \\
\hline 20 & .47 & .33 & .36 & .25 & .13 & .09 & $\mathrm{e} 13$ & 6.9 & e783 & .37 & .55 & .46 \\
\hline 21 & .45 & .40 & .35 & .24 & .13 & .09 & e. 31 & 74 & 7.6 & .38 & 3.7 & .48 \\
\hline 22 & .37 & .34 & .37 & .23 & .14 & .09 & e. 21 & 23 & .71 & .50 & 16 & .40 \\
\hline 23 & .38 & .39 & .44 & .26 & .14 & .09 & e. 12 & 4.9 & .54 & .40 & 1.1 & .34 \\
\hline 24 & .39 & .34 & .49 & .26 & .15 & .09 & 59 & .51 & .54 & .40 & .48 & .32 \\
\hline 25 & .35 & .34 & .35 & .24 & .15 & .09 & 69 & .22 & .53 & .39 & .45 & .37 \\
\hline 26 & .30 & .33 & .32 & .24 & .14 & .09 & 45 & .19 & .53 & .38 & .44 & .39 \\
\hline 27 & .35 & .40 & .33 & .23 & .14 & .09 & 34 & .17 & .52 & .38 & .41 & .43 \\
\hline 28 & .43 & .37 & .32 & .22 & .14 & .14 & 17 & .17 & .53 & .89 & .31 & .53 \\
\hline AC-FT & 22 & 22 & 22 & 17 & 9.9 & 42 & 759 & 821 & 4,120 & 108 & 65 & 692 \\
\hline CFSM & .00 & .00 & .00 & .00 & .00 & .00 & .03 & .03 & .15 & .00 & .00 & .02 \\
\hline
\end{tabular}

${ }^{1}$ Month in which data are provisional, subject to revision. 
Table 12. Discharge data, Polacca Wash near Second Mesa, Arizona (09400568), calendar year 2004.

[e, estimated. Dashes indicate no data]

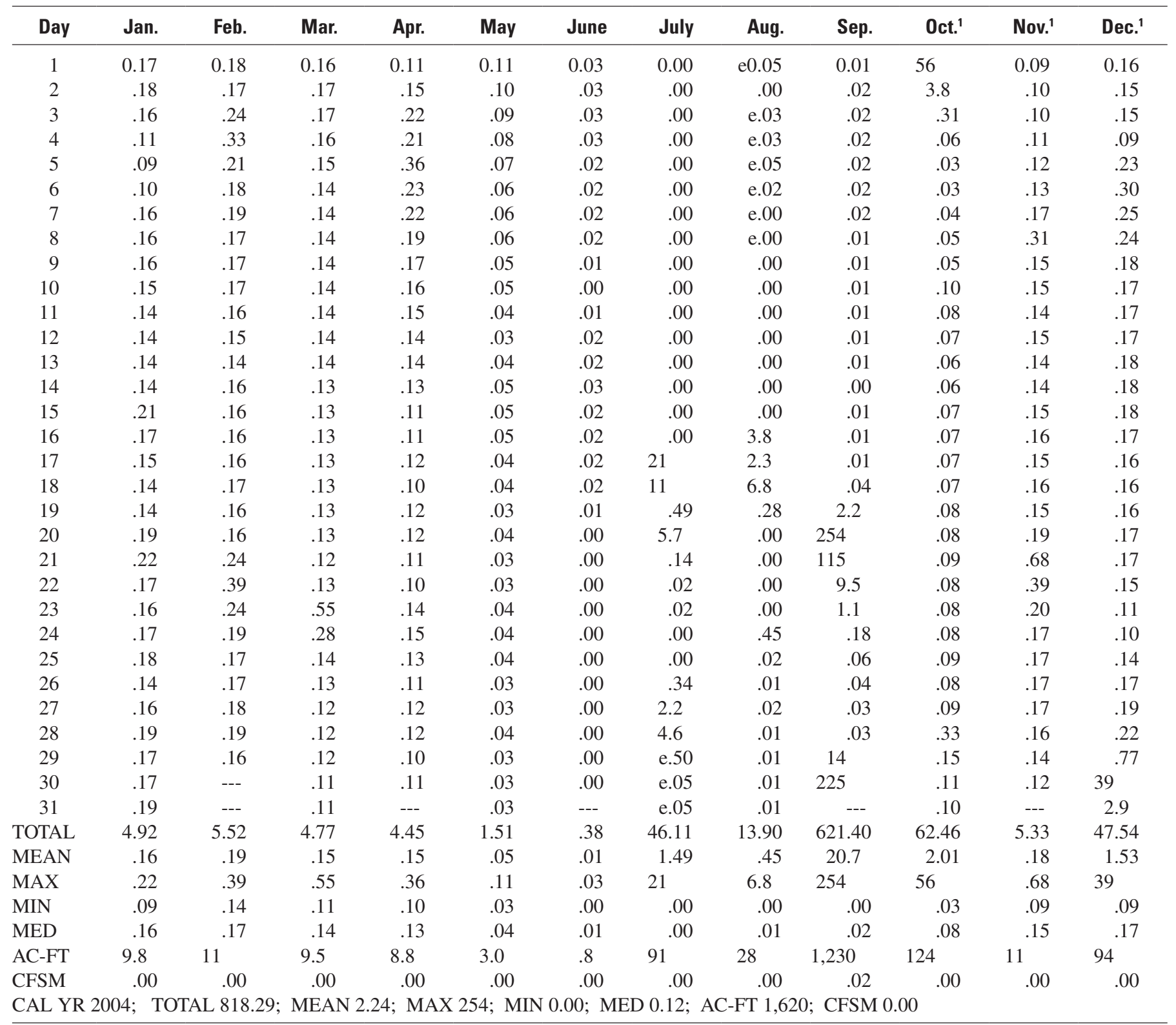

${ }^{1}$ Month in which data are provisional, subject to revision. 
Table 13. Discharge data, Pasture Canyon Spring near Tuba City, Arizona (09401265), August through December, calendar year 2004.

[e, estimated. Dashes indicate no data]

\begin{tabular}{|c|c|c|c|c|c|c|c|c|c|c|c|c|}
\hline Day & Jan. & Feb. & Mar. & Apr. & May & June & July & Aug. & Sep. & Oct. ${ }^{1}$ & Nov. ${ }^{1}$ & Dec. ${ }^{1}$ \\
\hline 1 & --- & --- & --- & --- & --- & --- & --- & --- & 0.26 & 0.32 & 0.38 & 0.41 \\
\hline 2 & --- & --- & --- & --- & --- & --- & --- & -- & .25 & .32 & .38 & .40 \\
\hline 3 & --- & --- & --- & --- & --- & --- & --- & --- & .26 & .32 & .38 & .40 \\
\hline 4 & --- & --- & --- & --- & --- & --- & --- & --- & .28 & .32 & .37 & .39 \\
\hline 5 & --- & --- & --- & --- & --- & --- & --- & --- & .27 & .32 & .36 & .39 \\
\hline 6 & --- & --- & --- & --- & --- & --- & --- & --- & .28 & .32 & .36 & .41 \\
\hline 7 & --- & --- & --- & --- & --- & --- & --- & --- & .28 & .32 & .36 & .41 \\
\hline 8 & --- & --- & --- & --- & --- & --- & --- & --- & .27 & .33 & .39 & .41 \\
\hline 9 & --- & --- & --- & --- & --- & --- & --- & --- & .28 & .34 & .41 & .40 \\
\hline 10 & --- & --- & --- & --- & --- & -- & --- & 0.25 & .28 & .34 & .41 & .38 \\
\hline 11 & --- & --- & --- & --- & --- & --- & --- & .25 & .28 & .34 & .40 & .38 \\
\hline 12 & --- & --- & --- & --- & --- & --- & --- & .26 & .28 & .34 & .39 & .38 \\
\hline 13 & --- & --- & --- & --- & --- & --- & --- & .26 & .28 & .34 & .38 & .38 \\
\hline 14 & --- & --- & --- & --- & --- & --- & --- & .26 & .28 & .34 & .38 & .38 \\
\hline 15 & --- & --- & --- & --- & --- & --- & --- & .26 & .28 & .34 & .38 & .38 \\
\hline 16 & --- & --- & --- & --- & --- & --- & --- & .29 & .28 & .34 & .38 & .38 \\
\hline 17 & --- & --- & --- & --- & --- & --- & --- & .27 & .28 & .34 & .38 & .38 \\
\hline 18 & --- & --- & --- & --- & --- & --- & --- & .26 & .30 & .34 & .38 & .38 \\
\hline 19 & --- & --- & --- & --- & --- & --- & --- & .26 & .34 & .34 & .38 & .38 \\
\hline 20 & --- & --- & --- & --- & --- & --- & --- & .27 & .31 & .34 & .39 & .38 \\
\hline 21 & --- & --- & --- & --- & --- & --- & --- & .26 & .31 & .36 & .46 & .38 \\
\hline 22 & --- & --- & --- & --- & --- & --- & --- & .26 & .30 & .38 & .44 & .38 \\
\hline 23 & --- & --- & --- & --- & --- & --- & --- & .26 & .30 & .38 & .42 & .38 \\
\hline 24 & --- & --- & --- & --- & --- & --- & --- & .26 & .30 & .37 & .41 & .38 \\
\hline 25 & --- & --- & --- & --- & --- & --- & --- & .26 & .30 & .36 & .41 & .38 \\
\hline 26 & --- & --- & --- & --- & --- & --- & --- & .25 & .30 & .36 & .41 & .38 \\
\hline 27 & --- & --- & --- & --- & --- & --- & --- & .25 & .30 & .36 & .41 & .38 \\
\hline 28 & --- & --- & --- & --- & --- & --- & --- & .26 & .31 & .40 & .41 & .38 \\
\hline 29 & --- & --- & --- & --- & --- & --- & -- & .26 & .36 & .38 & .41 & e. 60 \\
\hline 30 & --- & --- & --- & --- & --- & --- & --- & .26 & .33 & .38 & .41 & e. 50 \\
\hline 31 & --- & --- & --- & --- & --- & --- & --- & .26 & --- & .38 & --- & e. 40 \\
\hline TOTAL & --- & --- & --- & --- & --- & --- & --- & --- & 8.73 & 10.76 & 11.83 & 12.34 \\
\hline MEAN & --- & --- & --- & --- & --- & --- & --- & --- & .29 & .35 & .39 & .40 \\
\hline MAX & --- & --- & --- & --- & --- & --- & --- & --- & .36 & .40 & .46 & .60 \\
\hline MIN & --- & --- & --- & --- & --- & --- & --- & --- & .25 & .32 & .36 & .38 \\
\hline MED & --- & --- & --- & --- & --- & --- & --- & --- & .28 & .34 & .39 & .38 \\
\hline AC-FT & --- & --- & --- & --- & --- & --- & --- & --- & 17 & 21 & 23 & 24 \\
\hline
\end{tabular}

${ }^{1}$ Month in which data are provisional, subject to revision. 
Table 14. Date that data collection began and drainage areas for streamflow-gaging stations, Black Mesa area, Arizona.

[Dashes indicate not determined]

\begin{tabular}{llrr}
\hline \multicolumn{1}{c}{ Station name } & Station No. & $\begin{array}{c}\text { Date data } \\
\text { collection began }\end{array}$ & $\begin{array}{c}\text { Drainage area } \\
\text { (square miles) }\end{array}$ \\
\hline Moenkopi Wash at Moenkopi & 09401260 & July 1976 & 1,629 \\
Laguna Creek at Dennehotso & 09379180 & July 1996 & 414 \\
Dinnebito Wash near Sand Springs & 09401110 & June 1993 & 473 \\
Polacca Wash near Second Mesa & 09400568 & April 1994 & 905 \\
Pasture Canyon Spring & 09401265 & August 2004 & --- \\
\hline
\end{tabular}

Discharge data from August through December 2004 for Pasture Canyon Spring is published in this report; however, they are not sufficient to enable evaluation of possible trends or provide comparisons to data for previous years. The annual average discharges at the other four gaging stations vary considerably during the stations' periods of record (fig. 11A), and no long-term trends are apparent except for Moenkopi Wash. Discharge of Moenkopi Wash shows a decreasing trend from 1983 to 1993 and an increasing trend from 1995 to 2003.

The ground-water discharge component of total flow at the four streamflow-gaging stations was estimated by computing the median flow for four winter monthsNovember, December, January, and February (fig. 11B). The 120 consecutive daily mean flows for those four months were used to compute the median flow. Ground-water discharge is assumed to be constant throughout the year, and the median winter flow is assumed to represent this constant annual ground-water discharge. Most flow during the winter is ground-water discharge; rainfall and snowmelt runoff are minimal. Most of the precipitation in the winter falls as snow, and the cold temperatures prevent appreciable snowmelt. Also, evapotranspiration is at a minimum during the winter. The median flow for November, December, January, and February, rather than the average flow, is used to estimate ground-water discharge because the median is less affected by occasional winter runoff.
The median flow for November, December, January, and February is an index of ground-water discharge rather than an absolute estimate of discharge. A more rigorous and accurate estimate would involve detailed evaluations of streamflow hydrographs, flows into and out of bank storage, gain and loss of streamflow as it moves down the stream channel, and interaction of ground water in the $\mathrm{N}$ aquifer with ground water in the shallow alluvial aquifers in the stream valleys. The median winter flow, however, is useful as a consistent index for evaluating possible time trends in ground-water discharge.

Median winter flows were calculated for the 2004 water year; thus, daily mean flows for November and December 2003 (Truini and others, 2005) were combined with daily mean flows for January and February 2004. These median winter flows were $2.65 \mathrm{ft}^{3} / \mathrm{s}$ for Moenkopi Wash, $0.56 \mathrm{ft}^{3} / \mathrm{s}$ for Laguna Creek, $0.34 \mathrm{ft}^{3} / \mathrm{s}$ for Dinnebito Wash, and $0.13 \mathrm{ft}^{3} / \mathrm{s}$ for Polacca Wash (fig. 11B). In 2004, flows for Moenkopi Wash and Laguna Creek both decreased, and flows for Polacca and Dinnebito Washes both increased (fig. 11B). Since 1995, the median flows for Moenkopi Wash, Dinnebito Wash, and Polacca Wash have generally decreased. Median flow values for Laguna Creek are available only since 1997 but no increasing or decreasing trend is apparent. Annual precipitation at Betatakin, about $15 \mathrm{mi}$ west of Kayenta (fig. 1), has been less than average for 6 of the 9 years since 1995 (fig. 11C). Precipitation data for 2003 are incomplete. Precipitation was above average for calendar year 2004 (19.8 in.; fig. $11 C$ ). 
A. Annual average discharge for calendar years 1977-2004

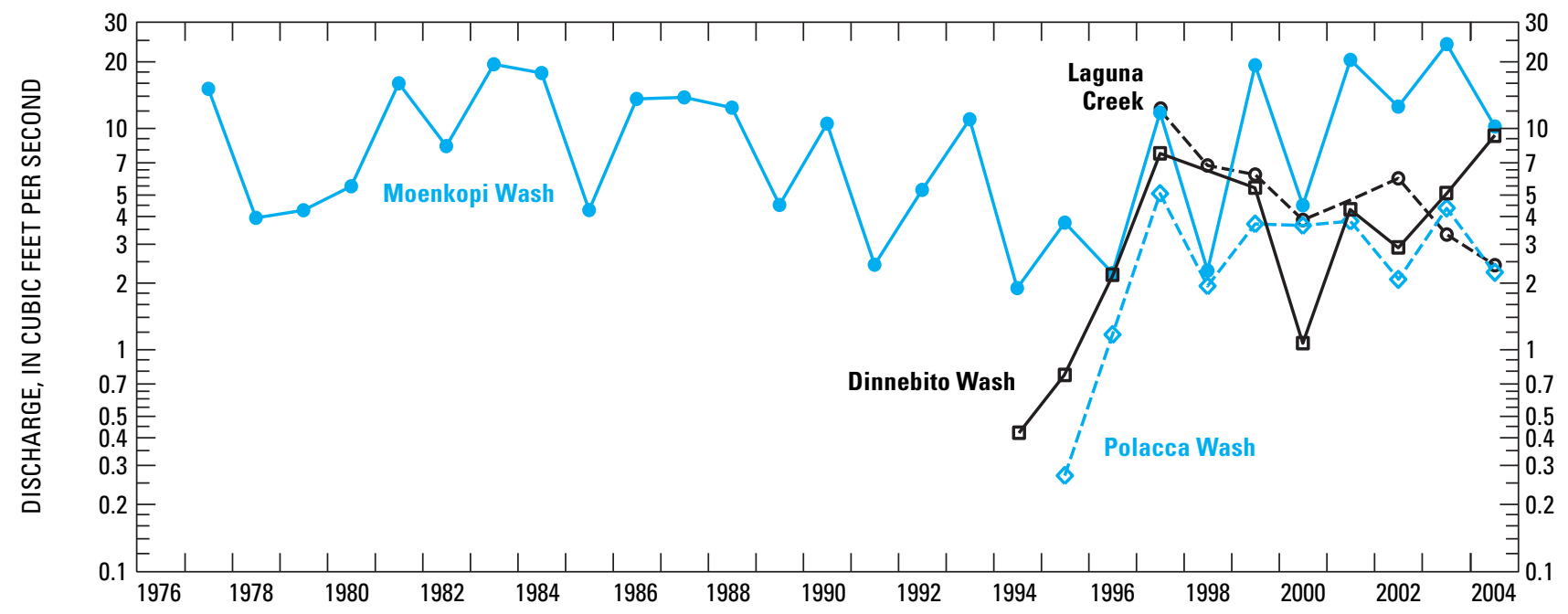

B. Median discharge for November, December, January, and February for water years 1977-2004

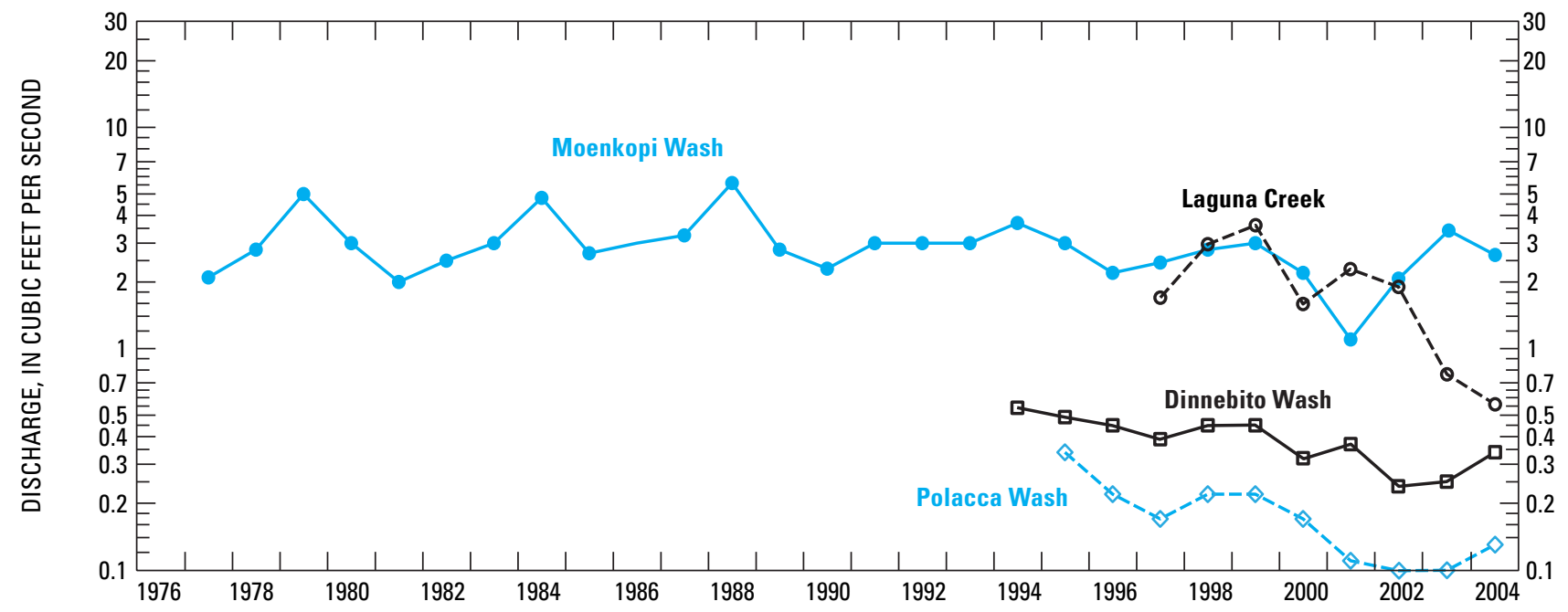

C. Annual precipitation at Betatakin, Arizona, calendar years 1976-2004 (National Weather Service)

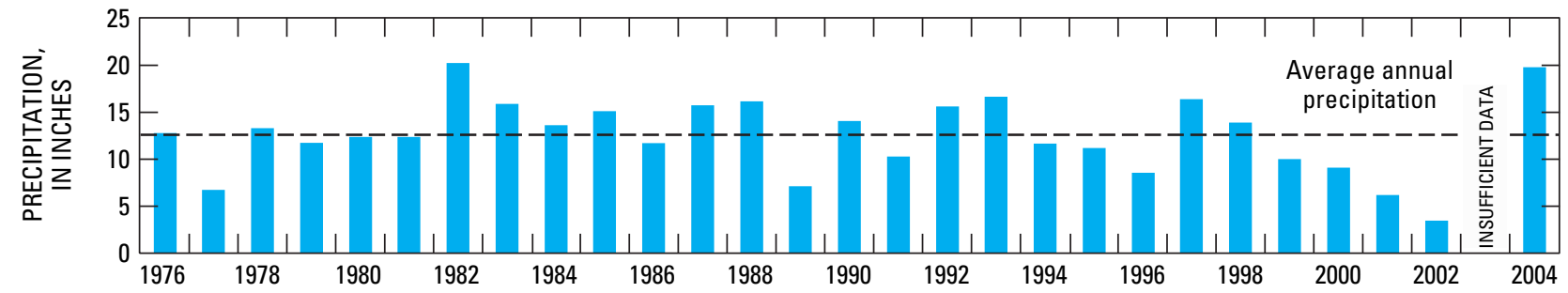

Figure 11. Annual precipitation at Betatakin, Arizona, and streamflow characteristics at Moenkopi Wash (09401260), Laguna Creek (09379180), Dinnebito Wash (09401110), and Polacca Wash (09400568), Black Mesa area, Arizona.

A, Annual average discharge for calendar years 1977-2004; B, Median discharge for November, December, January, and February for water years 1977-2004; C, Annual precipitation at Betatakin, Arizona, calendar years 1976-2004 (National Weather Service). 


\section{Water Chemistry}

Water samples are collected from selected wells and springs each year of the Black Mesa monitoring program. Field measurements are made and water samples are analyzed for major ions, nutrients, iron, boron, and arsenic. Samples typically are collected from 12 wells and 4 springs in each year of the program - from the same 8 wells every year and from the other 4 wells on a rotational basis. In 2005, samples could not be collected at Pĩnon PM1 because of well maintenance and repairs. Since 1989, samples have been collected from the same 4 springs. Long-term data for specific conductance, total dissolved solids, chloride, and sulfate for the wells and springs sampled each year are shown in the report published for that year. Historical data for other constituents for all the wells and springs are available from the USGS water-quality database (http://waterdata.usgs.gov/az/ nwis/qw) or can be found in the past monitoring reports that are cited in the "Previous Investigations" section of this report.

\section{Water Chemistry from Wells Completed in the N Aquifer}

The primary types of water in the $\mathrm{N}$ aquifer are calcium bicarbonate and sodium bicarbonate. Calcium bicarbonate water generally is in the recharge areas of the northern and northwestern parts of the Black Mesa area, and sodium bicarbonate water is in the area that is downgradient to the south and east (Lopes and Hoffmann, 1997). In 2005, water samples were collected from 11 wells completed in the $\mathrm{N}$ aquifer (figs. 9 and 12). Sample analyses indicated primarily sodium bicarbonate water except for samples from Kayenta PM2 which is in the western part of the confined area of the $\mathrm{N}$ aquifer and Shonto PM2, which is in the western part of the unconfined recharge area of the $\mathrm{N}$ aquifer (fig. 12 and table 15).

Rough Rock PM5 and Keams Canyon PM2 yielded appreciably higher dissolved-solids concentrations $(639 \mathrm{mg} / \mathrm{L}$ and $601 \mathrm{mg} / \mathrm{L}$, respectively) than did the other 9 wells (fig. 12 and table 15). Concentrations of dissolved solids in samples from the other 9 wells ranged from $122 \mathrm{mg} / \mathrm{L}$ at Peabody 6 to $361 \mathrm{mg} / \mathrm{L}$ at Second Mesa PM2 (fig. 12 and table 15).

There are some long-term trends in the chemistry of water samples from the 7 wells having more than 10 years of data (table 16 and fig. 13). Rough Rock PM5, Keams Canyon PM2, Second Mesa PM2, and Kayenta PM2 show an increasing trend in dissolved solids; Forest Lake NTUA 1 and Peabody 2 show a decreasing trend in dissolved solids, and Kykostmovi PM2 shows a steady trend (fig. 13). The chemistry of water samples from Forest Lake NTUA 1 has varied considerably between 1982 and 2005 (table 16 and fig. 13).

Constituents analyzed from the 11 well samples were compared to U.S. Environmental Protection Agency (USEPA) Primary and Secondary Drinking-Water Regulations (U.S. Environmental Protection Agency, 2002). Maximum Contaminant Levels (MCLs), which are the primary regulations, are legally enforceable standards that apply to public water systems. MCLs protect drinking-water quality by limiting the levels of specific contaminants that can adversely affect public health. Secondary Maximum Contaminant Levels (SMCLs) provide guidelines for the control of contaminants that may cause cosmetic effects (such as skin or tooth discoloration) or aesthetic effects (such as taste, odor, or color) in drinking water. The USEPA recommends compliance with SMCLs for public water systems; however, compliance is not required.

The concentrations of most of the analyzed constituents from the 11 wells sampled in 2005 were less than MCLs and SMCLs (table 15). The pH, however, exceeded the SMCL maximum $\mathrm{pH}$ of 8.5 units in samples from 9 of the 11 wells. The dissolved-solids SMCL of $500 \mathrm{mg} / \mathrm{L}$ was exceeded in the sample from Rough Rock PM5 (639 mg/L) and Keams Canyon PM2 (601 mg/L). Samples from three wells, Keams Canyon PM2 (42.7 $\mu \mathrm{g} / \mathrm{L})$, Rough Rock PM5 (50.8 $\mu \mathrm{g} / \mathrm{L})$, and Second Mesa PM2 $(16.3 \mu \mathrm{g} / \mathrm{L})$ had arsenic concentrations that exceeded the MCL of $10 \mu \mathrm{g} / \mathrm{L}(0.01 \mathrm{mg} / \mathrm{L}$; table 15 ; U.S. Environmental Protection Agency, 2002).

\section{Water Chemistry from Springs that Discharge from the N Aquifer}

In 2005, water samples were collected from four springs in the study area. Burro Spring is in the southern part of the study area, the unnamed spring near Dennehotso is in the northeastern part, and Moenkopi School Spring and Pasture Canyon Spring are in the western part (fig. 9). All the springs discharge water from unconfined areas of the $\mathrm{N}$ aquifer. At Burro Spring, samples are collected from a metal pipe that discharges from a holding tank. At Moenkopi School Spring, samples are collected from a horizontal metal pipe that is developed into the hillside. At the unnamed spring near Dennehotso, samples are collected from a cavity dug into the sand where the water discharges from the bedrock. At Pasture Canyon Spring, samples are collected from a pipe at the end of a channel and approximately 50 feet away from the spring. 


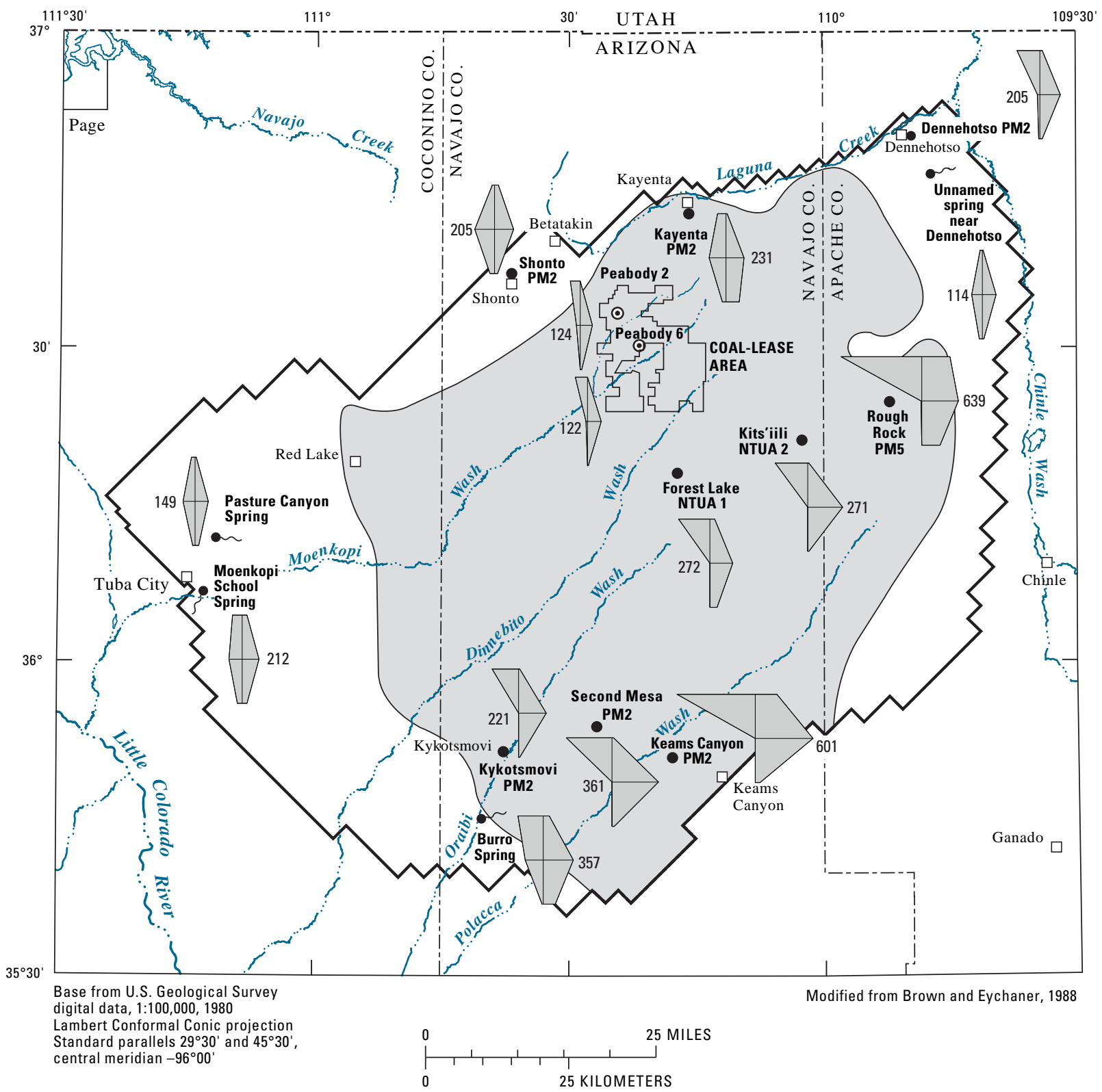

EXPLANATION

CONFINED AND UNCONFINED CONDITIONS IN THE N AOUIFER WITHIN MODEL BOUNDARY

Confined

Unconfined

APPROXIMATE BOUNDARY BETWEEN CONFINED AND UNCONFINED CONDITIONS From Brown and Eychaner (1988)

BOUNDARY OF MATHEMATICAL MODEL-From Brown and Eychaner (1988)
MUNICIPAL WELL FROM WHICH WATER-CHEMISTRY SAMPLE WAS COLLECTED-Rough Rock PM5 is well name

INDUSTIAL WELL FROM WHICH

Peabody 6 WATER-CHEMISTRY SAMPLE

WAS COLLECTED-Peabody 6 is a well number

$\begin{array}{ll}\sim & \text { SPRING AT WHICH DISCHARGE } \\ \text { Burro } & \text { WAS MEASURED AND WATER- } \\ \text { Spring } & \text { CHEMISTRY SAMPLE WAS } \\ & \text { COLLECTED }\end{array}$

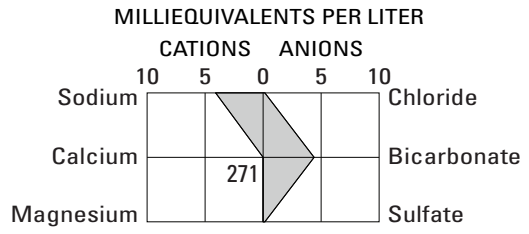

WATER-CHEMISTRY DIAGRAM-Shows major chemical constituents in milliequivalents per liter (meq/L). The diagram can be used to compare and characterize types of water. Number, 271, is dissolved-solids concentration, in milligrams per liter.

Figure 12. Water chemistry and distribution of dissolved solids in the N aquifer, Black Mesa area, Arizona, 2005. 


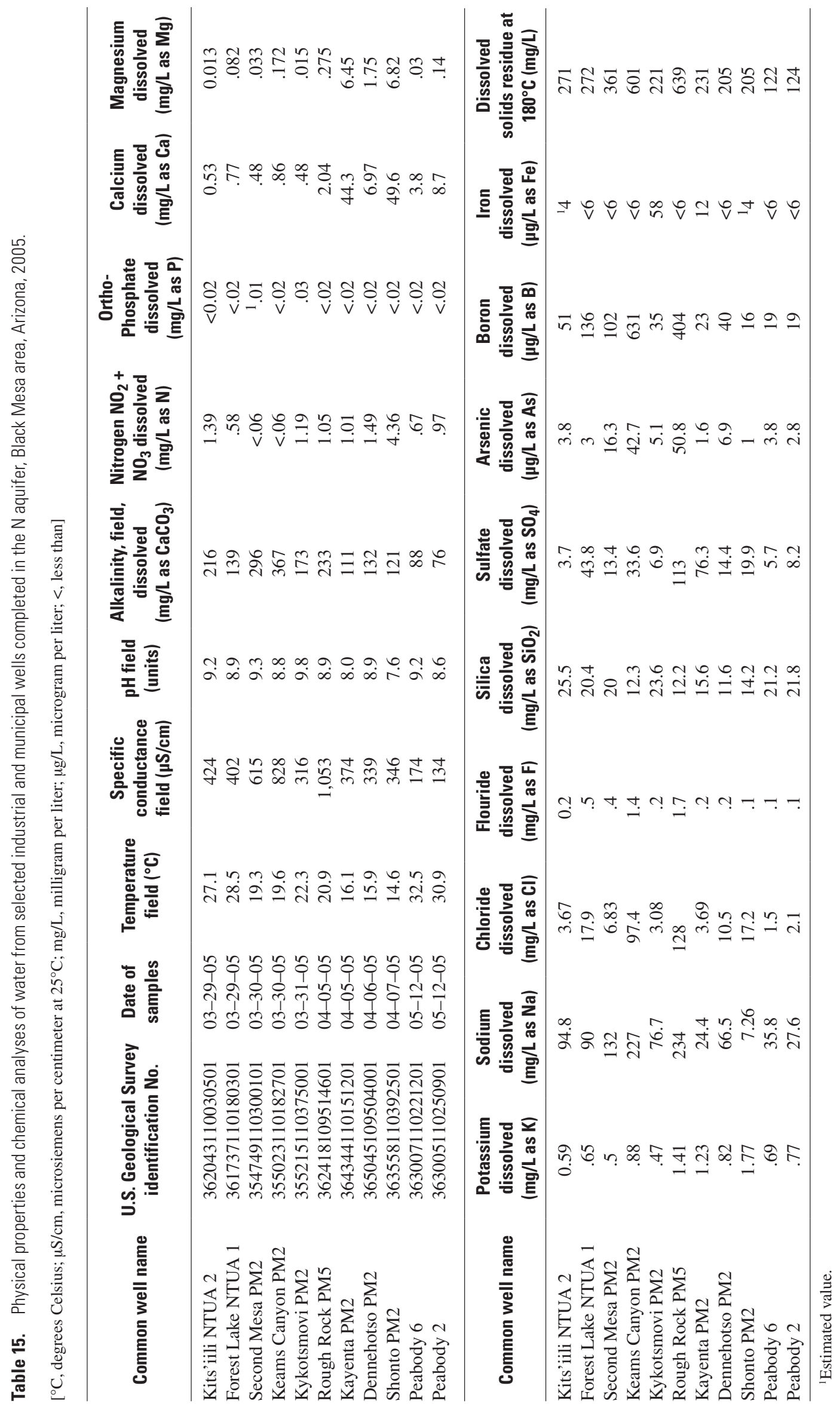


Table 16. Specific conductance and concentrations of selected chemical constituents in water from industrial and municipal wells completed in the N aquifer, Black Mesa area, Arizona, 1974-2005.

$\left[\mu \mathrm{S} / \mathrm{cm}\right.$, microsiemens per centimeter at $25^{\circ} \mathrm{C} ;{ }^{\circ} \mathrm{C}$, degrees Celsius; $\mathrm{mg} / \mathrm{L}$, milligram per liter; <, less than. Dashes indicate no data]

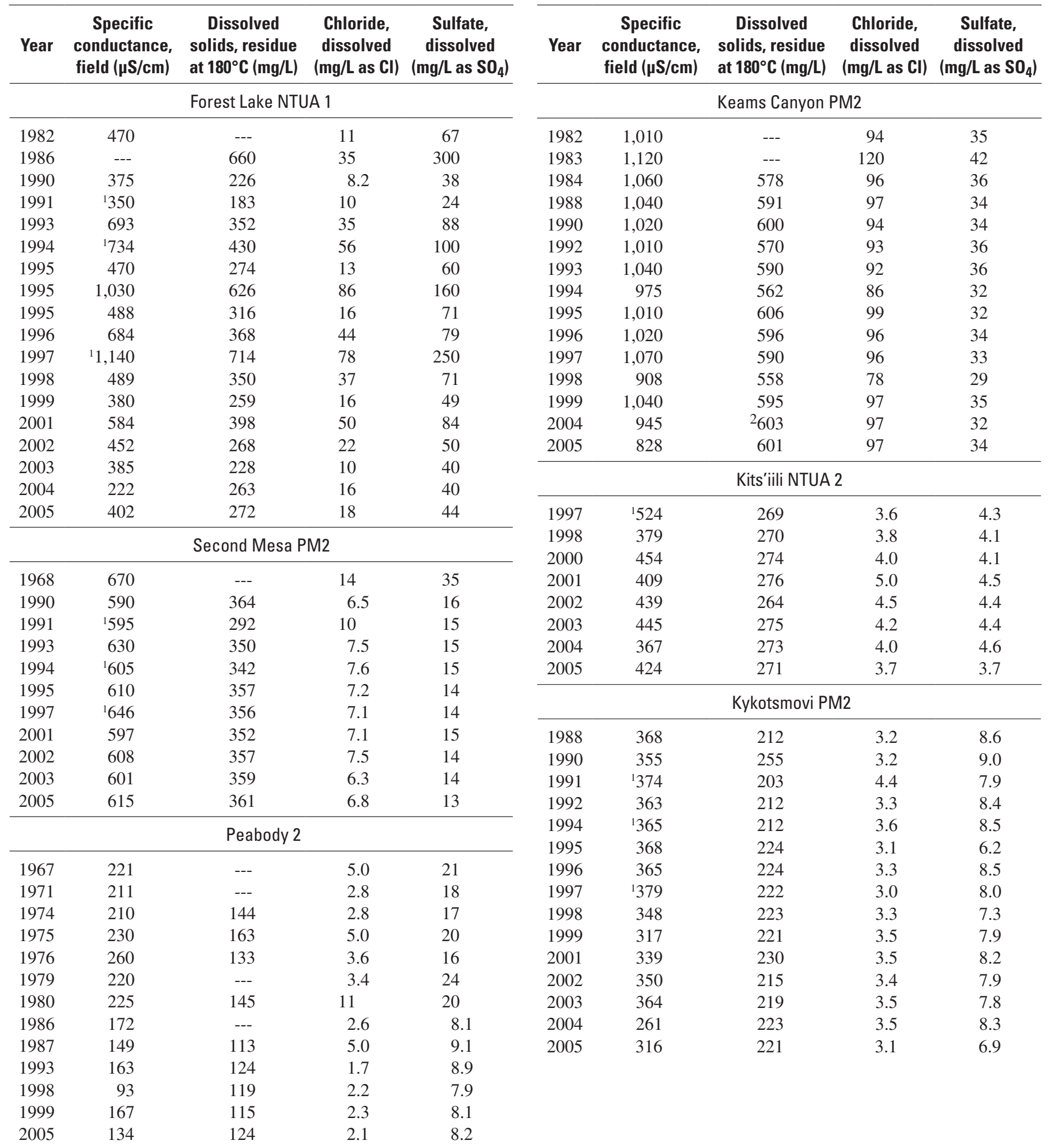


Table 16. Specific conductance and concentrations of selected chemical constituents in water from industrial and municipal wells completed in the $\mathrm{N}$ aquifer, Black Mesa area, Arizona, 1974-2005.-Continued

$\left[\mu \mathrm{S} / \mathrm{cm}\right.$, microsiemens per centimeter at $25^{\circ} \mathrm{C} ;{ }^{\circ} \mathrm{C}$, degrees Celsius; $\mathrm{mg} / \mathrm{L}$, milligram per liter; <, less than. Dashes indicate no data]

\begin{tabular}{|c|c|c|c|c|c|c|c|c|c|}
\hline Year & $\begin{array}{c}\text { Specific } \\
\text { conductance, } \\
\text { field }(\mu \mathrm{S} / \mathrm{cm})\end{array}$ & $\begin{array}{c}\text { Dissolved } \\
\text { solids, residue } \\
\text { at } 180^{\circ} \mathrm{C}(\mathrm{mg} / \mathrm{L})\end{array}$ & $\begin{array}{c}\text { Chloride, } \\
\text { dissolved } \\
\text { (mg/L as Cl) }\end{array}$ & $\begin{array}{c}\text { Sulfate, } \\
\text { dissolved } \\
\left(\mathrm{mg} / \mathrm{L} \text { as } \mathrm{SO}_{4}\right)\end{array}$ & Year & 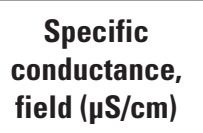 & $\begin{array}{l}\text { Dissolved } \\
\text { solids, residue } \\
\text { at } 180^{\circ} \mathrm{C}(\mathrm{mg} / \mathrm{L})\end{array}$ & $\begin{array}{l}\text { Chloride, } \\
\text { dissolved } \\
\text { (mg/L as CI) }\end{array}$ & $\begin{array}{c}\text { Sulfate, } \\
\text { dissolved } \\
\left(\mathrm{mg} / \mathrm{L} \text { as } \mathrm{SO}_{4}\right)\end{array}$ \\
\hline 1964 & 350 & --- & 12 & 31 & 1961 & 290 & --- & 10 & 16 \\
\hline 1992 & 226 & 131 & 9.8 & 19 & 1973 & 280 & --- & 7.1 & 20 \\
\hline 1999 & 314 & 196 & 14 & 15 & 1992 & 321 & 186 & 22 & 19 \\
\hline 2005 & 339 & 205 & 10.5 & 14 & 1993 & 324 & 197 & 17 & 16 \\
\hline \multirow{2}{*}{\multicolumn{5}{|c|}{ Peabody 6}} & 1996 & 323 & 188 & 15 & 17 \\
\hline & & & & & 2002 & 355 & 215 & 22 & 22 \\
\hline 1968 & 201 & --- & 3.0 & 13 & 2003 & 357 & 239 & 20 & 22 \\
\hline 1974 & 500 & 333 & 11.0 & 40 & 2005 & 346 & 205 & 17 & 20 \\
\hline 1986 & 182 & --- & 2.3 & 9.6 & 1983 & 375 & $\left({ }^{3}\right)$ & 5.9 & 60 \\
\hline 1988 & 173 & 127 & 2.4 & 9.1 & 1984 & 1370 & 209 & 4.2 & 51 \\
\hline 1993 & 181 & 126 & 1.9 & 6.6 & 1986 & 300 & 181 & 8.2 & 30 \\
\hline 1996 & 177 & 122 & 1.5 & 6 & 1988 & 358 & 235 & 3.8 & 74 \\
\hline 2005 & 174 & 122 & 1.5 & 5.7 & 1992 & 383 & 210 & 5.6 & 78 \\
\hline \multirow{2}{*}{\multicolumn{5}{|c|}{ Rough Rock PM5 }} & 1993 & 374 & 232 & 3.7 & 78 \\
\hline & & & & & 1994 & 1371 & 236 & 4.2 & 77 \\
\hline 1964 & 1,120 & $\left({ }^{3}\right)$ & 100 & 110 & 1995 & 371 & 250 & 4.2 & 72 \\
\hline 1970 & 610 & $\left({ }^{3}\right)$ & 13 & 50 & 1996 & 370 & 238 & 3.8 & 76 \\
\hline 1983 & 1,090 & $\left({ }^{3}\right)$ & 130 & 110 & 1997 & 379 & 230 & 3.9 & 77 \\
\hline 1984 & ${ }^{1} 1,100$ & 613 & 130 & 99 & 1998 & 349 & 236 & 3.7 & 71 \\
\hline 1986 & 1,010 & 633 & 140 & 120 & 1999 & 364 & 236 & 4.0 & 72 \\
\hline 1998 & 894 & 637 & 133 & 112 & & & & & \\
\hline 1999 & 1,050 & 630 & 129 & 110 & & & & & \\
\hline 2001 & 980 & 628 & 125 & 110 & & & & & \\
\hline 2002 & 1,120 & 636 & 129 & 109 & & & & & \\
\hline 2003 & 1,080 & 642 & 127 & 110 & & & & & \\
\hline 2004 & 653 & 649 & 128 & 109 & & & & & \\
\hline 2005 & 1,053 & 639 & 128 & 113 & & & & & \\
\hline
\end{tabular}

${ }^{1}$ Value is different in Black Mesa monitoring reports printed before 2000. The earlier reports showed values determined by laboratory analysis.

${ }^{2}$ Value changed from Black Mesa monitoring report for 2003-2004.

${ }^{3}$ Value is different in Black Mesa monitoring reports printed before 2000. The earlier reports showed values determined by the sum of constituents.

${ }^{4}$ Value is different in Black Mesa monitoring reports printed before 2000. The earlier reports applied a different rounding definition. 


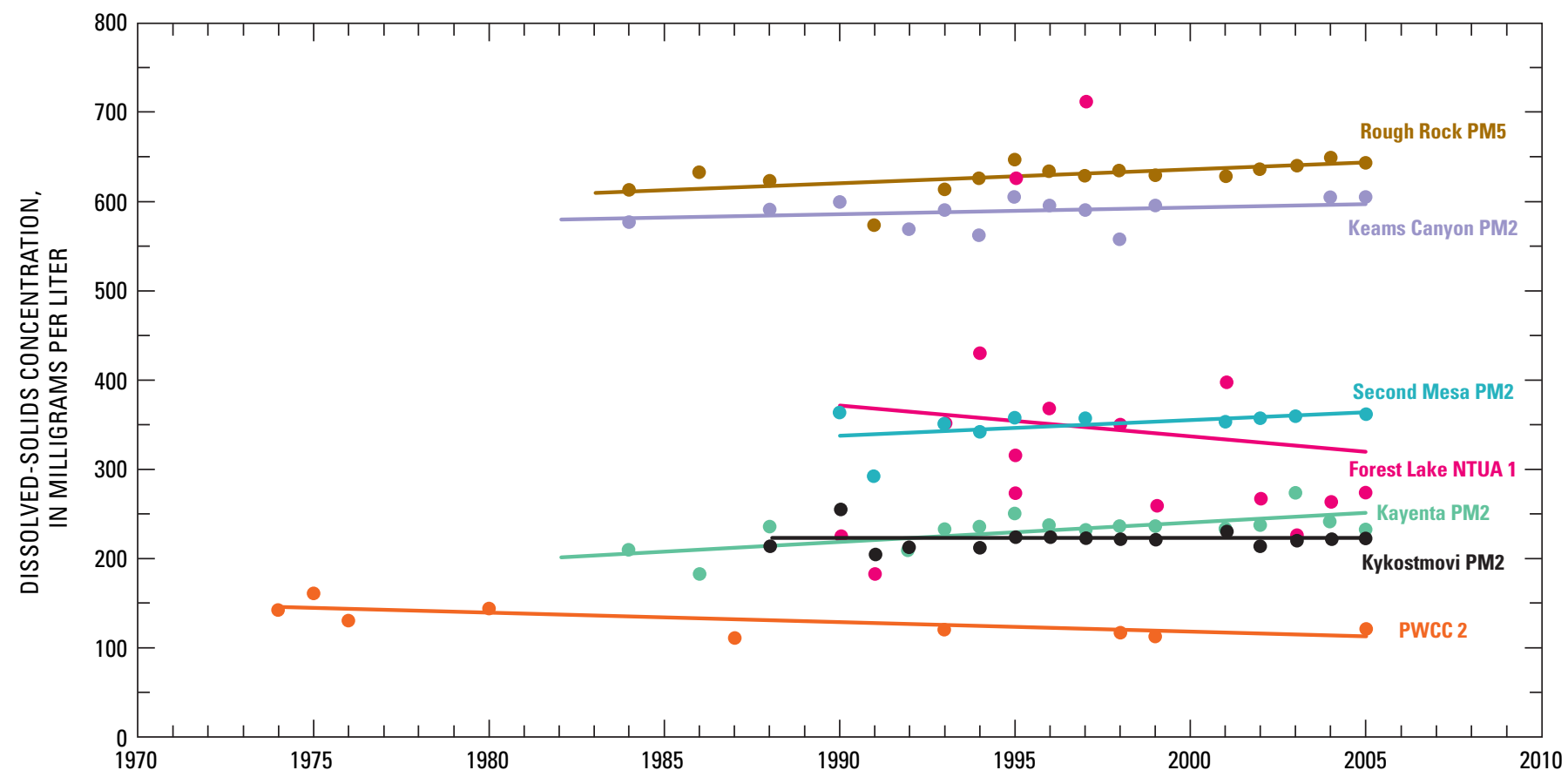

Figure 13. Dissolved-solids concentrations with linear trend lines for water from selected wells, Black Mesa area, Arizona, $1980-2005$.

Two water types were identified from the samples from the four springs. The unnamed spring near Dennehotso and Pasture Canyon Spring yielded a calcium bicarbonate type water, and Burro Spring and Moenkopi School Spring yielded a calcium sodium bicarbonate type water (fig. 12). Samples from the unnamed spring near Dennehotso, Moenkopi School Spring, and Pasture Canyon Spring had low dissolved-solids concentrations that ranged from 114 to $212 \mathrm{mg} / \mathrm{L}$ (table 17). The sample from Burro Spring had a dissolved-solids concentration of $357 \mathrm{mg} / \mathrm{L}$. Concentrations of all the analyzed constituents in samples from the four springs were less than current USEPA MCLs and SMCLs (U.S. Environmental Protection Agency, 2002).

No long-term trends, since the mid-1980s, are apparent in concentrations of dissolved solids, chloride, and sulfate in water samples from the unnamed spring near Dennehotso and Pasture Canyon Spring (table 18 and fig. 14A-C). Increasing trends in concentrations of dissolved solids and chloride are evident in data from Burro Spring and Moenkopi School Spring, and an increasing trend in sulfate is evident in data from Moenkopi School Spring (table 18 and figs. 14A-C). 
Table 17. Physical properties and chemical analyses of water from selected springs that discharge from the N aquifer, Black Mesa area, Arizona, 2005.

$\left[{ }^{\circ} \mathrm{C}\right.$, degree Celsius; $\mu \mathrm{S} / \mathrm{cm}$, microsiemens per centimeter at $25^{\circ} \mathrm{C} ; \mathrm{mg} / \mathrm{L}$, milligram per liter; $\mu \mathrm{g} / \mathrm{L}$, microgram per liter; $<$, less than. Dashes indicate no data]

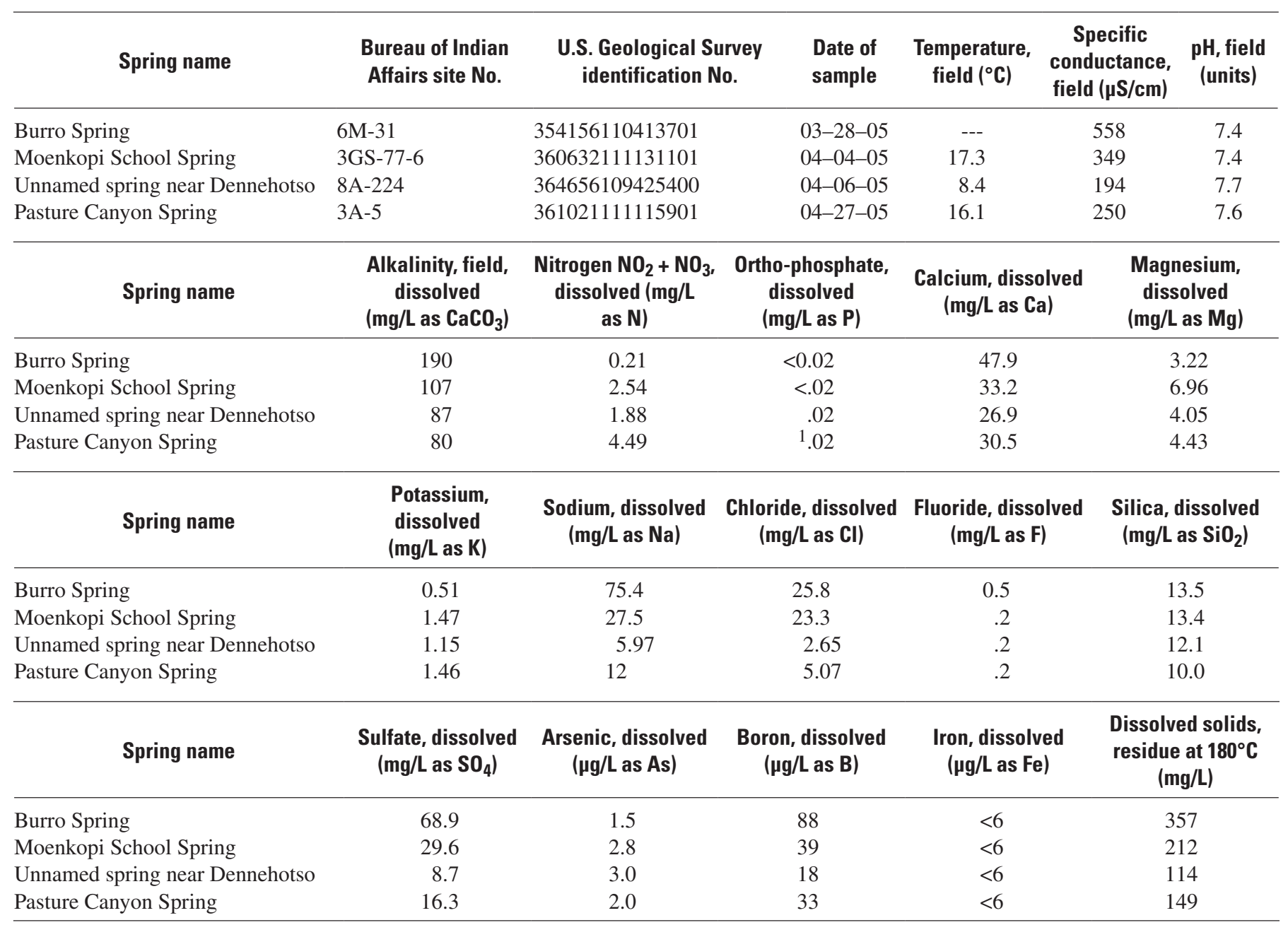

${ }^{1}$ Estimated value. 
Table 18. Specific conductance and concentrations of selected chemical constituents in water from selected springs that discharge from the $\mathrm{N}$ aquifer, Black Mesa area, Arizona, 1948-2005.

[ $\mathrm{HS} / \mathrm{cm}$, microsiemens per centimeter at $25^{\circ} \mathrm{C} ; \mathrm{mg} / \mathrm{L}$, milligrams per liter; ${ }^{\circ} \mathrm{C}$, degrees Celsius. Dashes indicate no data]

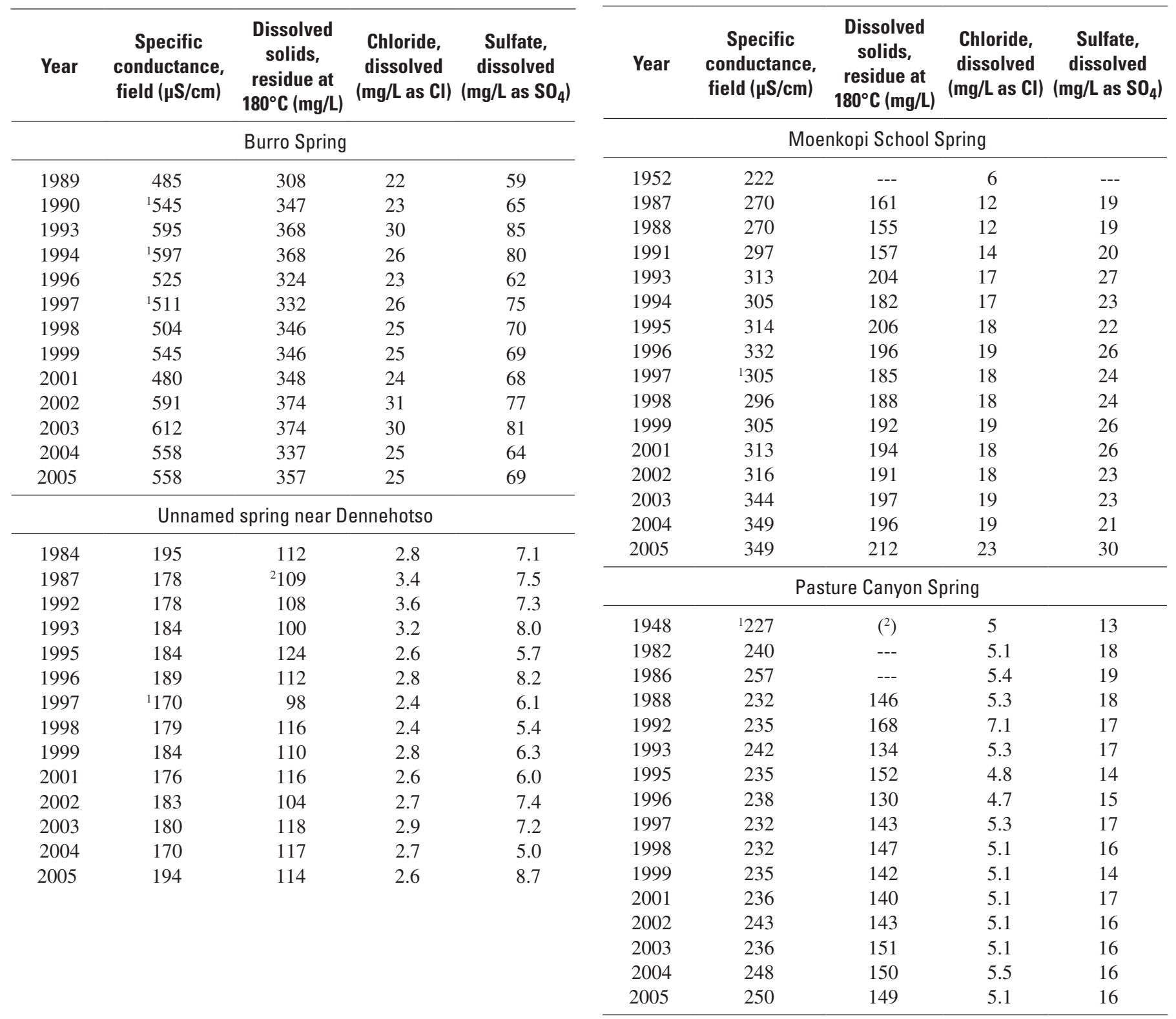

${ }^{1}$ Value is different in Black Mesa monitoring reports before 2000. Earlier reports showed values determined by laboratory analysis.

${ }^{2}$ Value is different in Black Mesa monitoring reports before 2000. Earlier reports showed values determined by the sum of constituents. 


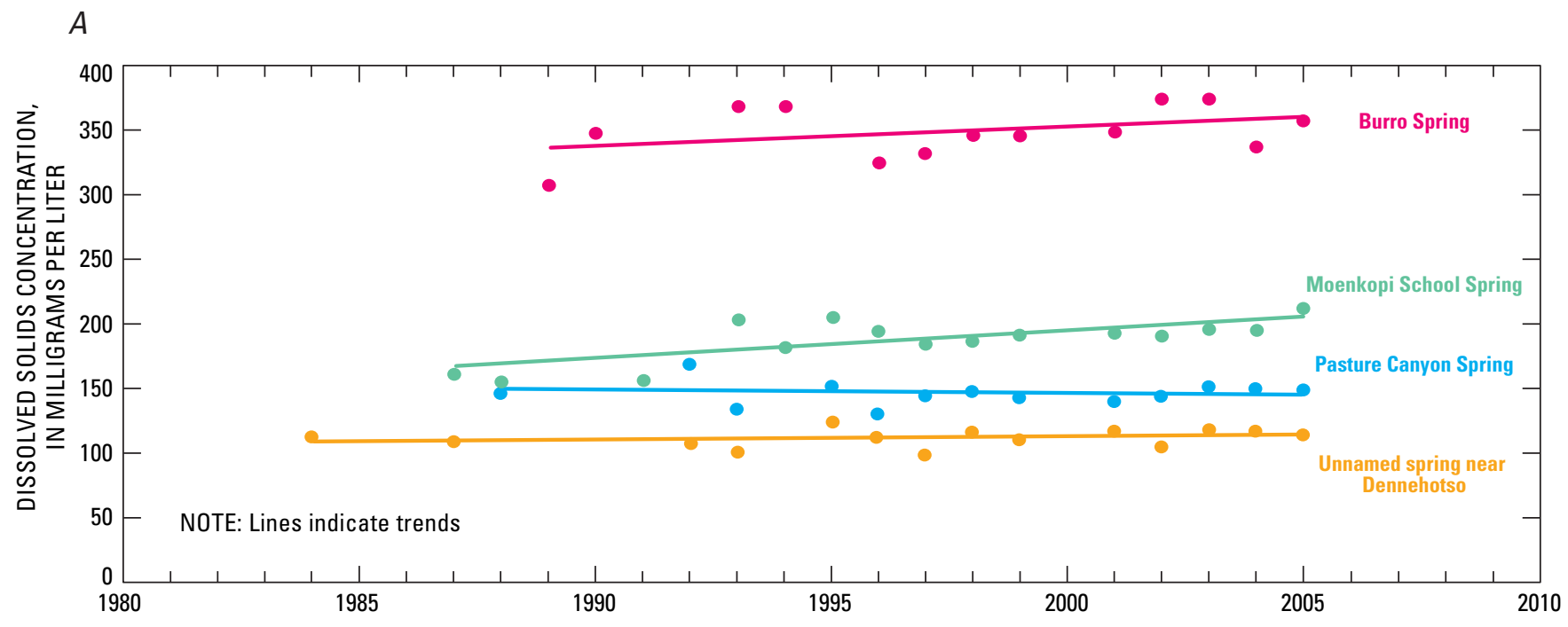

\section{$B$}

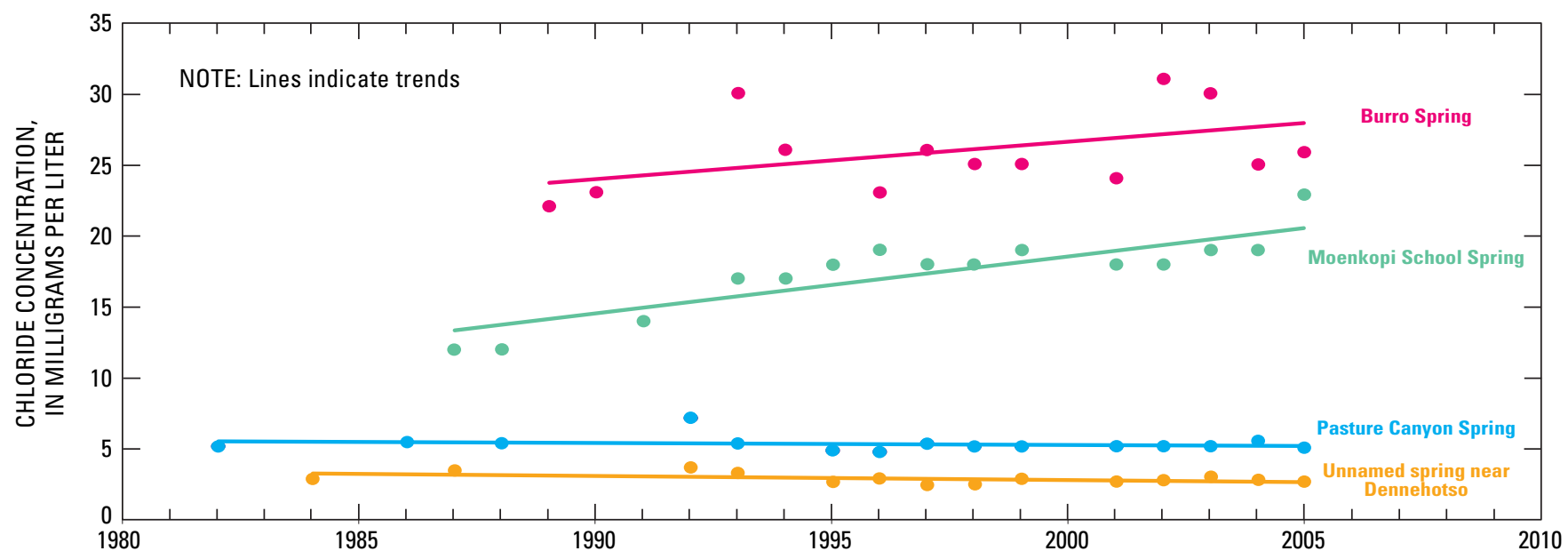

C

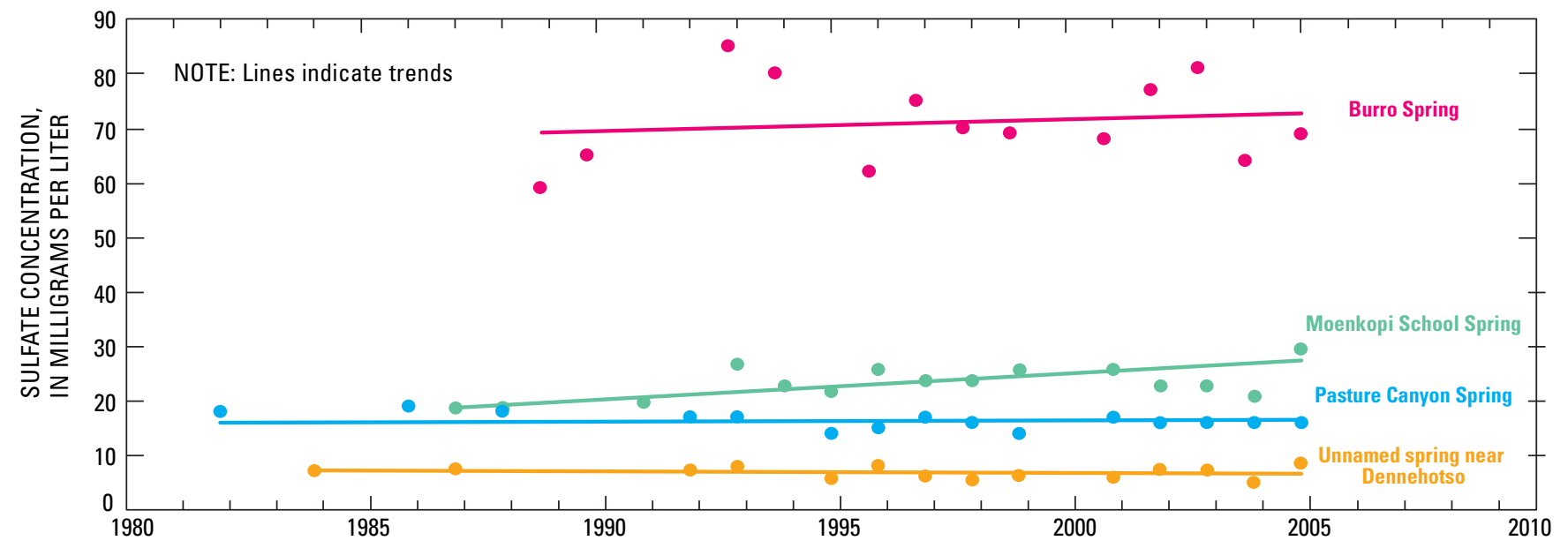

Figure 14. Concentrations of dissolved solids, chloride, and sulfate for water from selected springs, Black Mesa area, Arizona, $1984-2005$. A, Dissolved solids; B, Chloride; C, Sulfate. 


\section{Summary}

The $\mathrm{N}$ aquifer is the major source of water for industrial and municipal users in the Black Mesa area of northeastern Arizona. Availability of water is an important issue in the Black Mesa area because of continued industrial and municipal use, a growing population, and precipitation of about 6 to 14 in. per year.

This report presents results of ground-water, surfacewater, and water-chemistry monitoring in the Black Mesa area from January 2004 to September 2005. The monitoring data for 2004-05 are compared with data for 2003-04 and with historical data from the 1950s to the present.

In 2004, total ground-water withdrawals were 7,210 acre-ft, industrial withdrawals were 4,370 acre-ft, and municipal withdrawals were 2,840 acre-ft. From 2003 to 2004, total withdrawals decreased by less than 1 percent, industrial withdrawals decreased by 2 percent, and municipal withdrawals increased by 2 percent.

From 2004 to 2005, annually measured ground-water levels declined in 14 of 25 wells. The median water-level change for the 25 wells was $-0.4 \mathrm{ft}$. In unconfined areas, water levels declined in 6 of 13 annual wells, and the median change was $-0.1 \mathrm{ft}$. In the confined area, water levels declined in 8 of 12 wells, and the median change was $-1.2 \mathrm{ft}$. For wells in the confined area, the median water-level change was $-1.7 \mathrm{ft}$, and there is no appreciable trend in the water-level changes from 1983 to 2005 . For wells in unconfined areas, the median water-level change was $0.2 \mathrm{ft}$, and there is no appreciable trend from 1983 to 2005.

From the prestress period (prior to 1965) to 2005, the median water-level change in 33 wells was $-9.0 \mathrm{ft}$. Water levels in the 16 wells in the unconfined areas of the aquifer had a median change of $-0.6 \mathrm{ft}$, and the changes ranged from $-33.2 \mathrm{ft}$ to $15.0 \mathrm{ft}$. Water levels in the 17 wells in the confined area of the aquifer had a median change of $-32.0 \mathrm{ft}$, and the changes ranged from $-193.3 \mathrm{ft}$ to $14.0 \mathrm{ft}$.

Discharges were measured annually at four springs in 2004 and 2005. Between 2004 and 2005, spring flow stayed the same at Burro Spring, increased by 71 percent at the unnamed spring near Dennehotso, decreased by 5 percent at Moenkopi School Spring, and increased by 8 percent at Pasture Canyon Spring. For about the past 12 years, discharges in the four springs have fluctuated; however, increasing or decreasing trends are not apparent.

Annual average discharges at four streamflow-gaging stations-Moenkopi Wash, Laguna Creek, Dinnebito Wash, and Polacca Wash-vary considerably during the periods of record. No trends are apparent in streamflow at the four gaging stations. Median flows for November, December, January, and February of each water year are used as an index of ground- water discharge to those streams. Since 1995, the median winter flows have decreased in Moenkopi Wash, Dinnebito Wash, and Polacca Wash. Since 1997, there is no increasing or decreasing trend apparent in the median winter flow in Laguna Creek.

In 2005, water samples were collected from 11 wells and analyzed for selected chemical constituents. Dissolved-solids concentrations ranged from 122 to $639 \mathrm{mg} / \mathrm{L}$, and samples from 9 of the wells had dissolved-solids concentrations less than the SMCL (500 mg/L). There are some long-term trends in the chemistry of water samples from 7 wells with more than 10 years of data.

Samples from Rough Rock PM5 exceeded the SMCL for dissolved solids, samples from Keams Canyon PM2, Rough Rock PM5, and Second Mesa PM2 exceeded the MCL for arsenic $(10 \mu \mathrm{g} / \mathrm{L})$, and samples from 9 of the 11 wells exceeded the SMCL maximum for $\mathrm{pH}$ (8.5).

Dissolved-solids concentrations in water samples from the unnamed spring near Dennehotso, Pasture Canyon Spring, and Moenkopi School Spring ranged from 114 to $212 \mathrm{mg} / \mathrm{L}$, and the dissolved-solids concentration in the water sample from Burro Spring was $357 \mathrm{mg} / \mathrm{L}$. From the mid-1980s to 2005 , long-term trends are not apparent in the concentrations of dissolved solids, chloride, and sulfate in water samples from the unnamed spring near Dennehotso and Pasture Canyon Spring. Increasing trends in concentrations of dissolved solids and chloride are evident in data from Burro Spring and Moenkopi School Spring, and an increasing trend in sulfate is evident in data from Moenkopi School Spring.

\section{Selected References}

Boner, F.C., Davis, R.G., and Duet, N.R., 1992, Waterresources data for Arizona, water year 1991: U.S. Geological Survey Water-Data Report AZ-91-1, 411 p.

Boner, F.C., Garrett, W.B., and Konieczki, A.D., 1989, Water-resources data for Arizona, water year 1988: U.S. Geological Survey Water-Data Report AZ-88-1, 391 p.

Boner, F.C., Konieczki, A.D., and Davis, R.G., 1991, Water-resources data for Arizona, water year 1990: U.S. Geological Survey Water-Data Report AZ-90-1, 381 p.

Boner, F.C., Smith, C.F., Garrett, W.B., and Konieczki, A.D., 1990, Water-resources data for Arizona, water year 1989: U.S. Geological Survey Water-Data Report AZ-89-1, 383 p.

Brown, J.G., and Eychaner, J.H., 1988, Simulation of five ground-water withdrawal projections for the Black Mesa area, Navajo and Hopi Indian Reservations, Arizona: U.S. Geological Survey Water-Resources Investigations Report 88-4000, 51 p. 
Cooley, M.E., Harshbarger, J.W., Akers, J.P., and Hardt, W.F., 1969, Regional hydrogeology of the Navajo and Hopi Indian Reservations, Arizona, New Mexico, and Utah: U.S. Geological Survey Professional Paper 521-A, 61 p.

Davis, G.E., Hardt, W.F., Thompson, L.K., and Cooley, M.E., 1963, Records of ground-water supplies, part 1, of Geohydrologic data in the Navajo and Hopi Indian Reservations, Arizona, New Mexico, and Utah: Arizona State Land Department Water- Resources Report 12-A, $159 \mathrm{p}$.

Dubiel, R.F., 1989, Sedimentology and revised nomenclature for the upper part of the upper Triassic Chinle Formation and the lower Jurassic Wingate Sandstone, northwestern New Mexico and northeastern Arizona, in Anderson, O.J., Lucas, S.G., Love, D.W., and Cather, S.M., eds., Southeastern Colorado Plateau: New Mexico Geological Society Fortieth Annual Field Conference, September 28-October 1, 1989, p. 213-223.

Eychaner, J.H., 1983, Geohydrology and effects of water use in the Black Mesa area, Navajo and Hopi Indian Reservations, Arizona: U.S. Geological Survey WaterSupply Paper 2201, 26 p.

Fisk, G.G., Duet, N.R., Evans, D.W., Angeroth, C.E., Castillo, N.K., and Longsworth, S.A., 2004, Water-resources data for Arizona, water year 2003: U.S. Geological Survey WaterData Report AZ-03-1, 326 p.

Fisk, G.G., Duet, N.R., McGuire, E.H., Angeroth, C.E., Castillo, N.K., and Smith C. F., 2005, Water-resources data for Arizona, water year 2004: U.S. Geological Survey Water-Data Report AZ-04-1 p.

GeoTrans, Inc., 1987, A two-dimensional finite-difference flow model simulating the effects of withdrawals to the $\mathrm{N}$ aquifer, Black Mesa area, Arizona: Boulder, Colorado, GeoTrans, Inc., report prepared for Peabody Western Coal Company.

Harshbarger, J.W., Lewis, D.D., Skibitzke, H.E., Heckler, W.L., and Kister, L.R., 1966, Arizona water: U.S. Geological Survey Water-Supply Paper 1648, 85 p.

Hart, R.J., and Sottilare, J.P., 1988, Progress report on the ground-water, surface-water, and quality-of-water monitoring program, Black Mesa area, northeastern Arizona-1987-88: U.S. Geological Survey Open-File Report 88-467, 27 p.

Hart, R.J., and Sottilare, J.P., 1989, Progress report on the ground-water, surface-water, and quality-of-water monitoring program, Black Mesa area, northeastern Arizona-1988-89: U.S. Geological Survey Open-File Report 89-383, 33 p.

Hill, G.W., 1985, Progress report on Black Mesa monitoring program-1984: U.S. Geological Survey Open-File Report 85-483, 24 p.
Hill, G.W., and Sottilare, J.P., 1987, Progress report on the ground-water, surface-water, and quality-of-water monitoring program, Black Mesa area, northeastern Arizona-1987: U.S. Geological Survey Open-File Report 87-458, $29 \mathrm{p}$.

Hill, G.W., and Whetten, M.I., 1986, Progress report on Black Mesa monitoring program-1985-86: U.S. Geological Survey Open-File Report 86-414, 23 p.

HSIGeoTrans, Inc., 1993, Investigation of the N- and Daquifer geochemistry and flow characteristics using major ion and isotopic chemistry, petrography, rock stress analyses, and dendrochronology in the Black Mesa area, Arizona: Boulder, Colorado, HSIGeoTrans, Inc., report prepared for Peabody Coal Company.

HSIGeoTrans, Inc., and Waterstone Environmental Hydrology and Engineering, Inc., 1999, A three-dimensional flow model of the D and N aquifers, Black Mesa Basin, Arizona: Boulder, Colorado, HSIGeoTrans, Inc., and Waterstone Environmental Hydrology and Engineering, Inc., report prepared for Peabody Western Coal Company.

Kister, L.R., and Hatchett, J.L., 1963, Selected chemical analyses of the ground water, part 2 of Geohydrologic data in the Navajo and Hopi Indian Reservations, Arizona, New Mexico, and Utah: Arizona State Land Department WaterResources Report 12-B, 58 p.

Littin, G.R., 1992, Results of ground-water, surface-water, and water-quality monitoring, Black Mesa area, northeastern Arizona-1990-91: U.S. Geological Survey WaterResources Investigations Report 92-4045, 32 p.

Littin, G.R., 1993, Results of ground-water, surface-water, and water-quality monitoring, Black Mesa area, northeastern Arizona- 1991-92: U.S. Geological Survey WaterResources Investigations Report 93-4111, 23 p.

Littin, G.R., Baum, B.M., and Truini, Margot, 1999, Groundwater, surface-water, and water-chemistry data, Black Mesa area, northeastern Arizona-1999: U.S. Geological Survey Open-File Report 98-653, 27 p.

Littin, G.R., and Monroe, S.A., 1995a, Results of groundwater, surface-water, and water-quality monitoring, Black Mesa area, northeastern Arizona-1992-93: U.S. Geological Survey Water-Resources Investigations Report 95-4156, $37 \mathrm{p}$.

Littin, G.R., and Monroe, S.A., 1995b, Results of groundwater, surface-water, and water-chemistry monitoring, Black Mesa area, northeastern Arizona-1994: U.S. Geological Survey Water-Resources Investigations Report 95-4238, 25 p.

Littin, G.R., and Monroe, S.A., 1996, Ground-water, surface-water, and water-chemistry data, Black Mesa area, northeastern Arizona-1995: U.S. Geological Survey OpenFile Report 96-616, 22 p. 
Littin, G.R., and Monroe, S.A., 1997, Ground-water, surfacewater, and water- chemistry data, Black Mesa area, northeastern Arizona-1996: U.S. Geological Survey OpenFile Report 97-566, 27 p.

Lopes, T.J., and Hoffmann, J.P., 1997, Geochemical analyses of ground-water ages, recharge rates, and hydraulic conductivity of the N Aquifer, Black Mesa area, Arizona: U.S. Geological Survey Water-Resources Investigations Report 96-4190, 42 p.

McCormack, H.F., Fisk, G.G., Duet, N.R., Evans, D.W., and Castillo, N.K., 2002, Water-resources data for Arizona, water year 2001: U.S. Geological Survey Water-Data Report AZ-01-1, 399 p.

McCormack, H.F., Fisk, G.G., Duet, N.R., Evans, D.W., Roberts, W.P., and Castillo, N.K., 2003, Water-resources data for Arizona, water year 2002: U.S. Geological Survey Water-Data Report AZ-02-1, 337 p.

Smith, C.F., Anning, D.W., Duet, N.R., Fisk, G.G., McCormack, H.F., Pope, G.L., Rigas, P.D., and Wallace, B.L., 1995, Water-resources data for Arizona, water year 1994: U.S. Geological Survey Water-Data Report AZ-94-1, $320 \mathrm{p}$.

Smith, C.F., Boner, F.C., Davis, R.G., Duet, N.R., and Rigas, P.D., 1993, Water-resources data for Arizona, water year 1992: U.S. Geological Survey Water-Data Report AZ-92-1, $360 \mathrm{p}$.

Smith, C.F., Rigas, P.D., Ham, L.K., Duet, N.R., and Anning, D.W., 1994, Water-resources data for Arizona, water year 1993: U.S. Geological Survey Water-Data Report AZ-93-1, $360 \mathrm{p}$.

Smith, C.F., Duet, N.R., Fisk, G.G., McCormack, H.F., Partin, C.K., Pope, G.L., Rigas, P.D., and Tadayon, Saeid, 1996, Water-resources data for Arizona, water year 1995: U.S. Geological Survey Water-Data Report AZ-95-1, 306 p.

Smith, C.F., Duet, N.R., Fisk, G.G., McCormack, H.F., Partin, C.K., Pope, G.L., and Rigas, P.D., 1997, Water-resources data for Arizona, water year 1996: U.S. Geological Survey Water-Data Report AZ-96-1, 328 p.

Sottilare, J.P., 1992, Results of ground-water, surfacewater, and water-quality monitoring, Black Mesa area, northeastern Arizona-1989-90: U.S. Geological Survey Water-Resources Investigations Report 92-4008, 38 p.

Tadayon, Saeid, Duet, N.R., Fisk, G.G., McCormack, H.F., Partin, C.K., Pope, G.L., and Rigas, P.D., 1999, Water-resources data for Arizona, water year 1998: U.S. Geological Survey Water-Data Report AZ-98-1, 454 p.

Tadayon, Saeid, Duet, N.R., Fisk, G.G., McCormack, H.F., Partin, C.K., Pope, G.L., and Rigas, P.D., 2000, Water-resources data for Arizona, water year 1999: U.S. Geological Survey Water-Data Report AZ-99-1, 389 p.
Tadayon, Saeid, Duet, N.R., Fisk, G.G., McCormack, H.F., Partin, C.K., Pope, G.L., and Rigas, P.D., 2001, Water-resources data for Arizona, water year 2000: U.S. Geological Survey Water-Data Report AZ-00-1, 390 p.

Tadayon, Saeid, Duet, N.R., Fisk, G.G., McCormack, H.F., Pope, G.L., and Rigas, P.D., 1998, Water-resources data for Arizona, water year 1997: U.S. Geological Survey WaterData Report AZ-97-1, 416 p.

Thomas, B.E., 2002a, Ground-water, surface-water, and waterchemistry data, Black Mesa area, northeastern Arizona2000-2001, and performance and sensitivity of the 1988 USGS numerical model of the N aquifer: U.S. Geological Survey Water-Resources Investigations Report 02-4211, $75 \mathrm{p}$.

Thomas, B.E., 2002b, Ground-water, surface-water, and water-chemistry data, Black Mesa area, northeastern Arizona-2001-02: U.S. Geological Survey Open-File Report 02-485, 43 p.

Thomas, B.E., and Truini, Margot, 2000, Ground-water, surface-water, and water-chemistry data, Black Mesa area, northeastern Arizona-1999: U.S. Geological Survey OpenFile Report 00-453, 42 p.

Truini, Margot, Baum, B.M., Littin, G.R., and ShingoitewaHonanie, Gayl, 2000, Ground-water, surface-water, and water-chemistry data, Black Mesa area, northeastern Arizona-1998: U.S. Geological Survey Open-File Report 00-66, 37 p.

Truini, Margot, and Longsworth, S.A., 2003, Hydrogeology of the D aquifer and movement and ages of ground water determined from geochemical and isotopic analyses, Black Mesa area, northeastern Arizona: U.S. Geological Survey Water-Resources Investigations Report 03-4189, 38 p.

Truini, Margot, and Thomas, B.E., 2004, Ground-water, surface-water, and water-chemistry data, Black Mesa area, northeastern Arizona-2002-03: U.S. Geological Survey Open-File Report 03-503, 43 p.

Truini, Margot, Macy, J.P., and Porter T.J., 2005, Groundwater, surface-water, and water-chemistry data, Black Mesa area, northeastern Arizona-2003-04: U.S. Geological Survey Open-File Report 2005-1080, 44 p.

U.S. Department of Agriculture, Natural Resources Conservation Service, 1999, Arizona annual precipitation: Fort Worth, Texas, USDA-NRCS National Cartography \& Geospatial Center, scale 1:1,300,000.

U.S. Environmental Protection Agency, 2002, Current drinking water standards, national primary and secondary drinking water regulations: Washington, D.C., U.S. Environmental Protection Agency, accessed January 31, 2006 at URL http:// www.epa.gov/safewater/mcl.html. 
U.S. Geological Survey, 1963-64a, Surface-water records of Arizona: U.S. Geological Survey report.

U.S. Geological Survey, 1963-64b, Ground-water records of Arizona: U.S. Geological Survey report.

U.S. Geological Survey, 1965-74a, Water-resources data for Arizona- Part 1, Surface-water records: U.S. Geological Survey Water-Resources Data Report.

U.S. Geological Survey, 1965-74b, Water-resources data for Arizona- Part 2, Ground-water records: U.S. Geological Survey Water-Resources Data Report.

U.S. Geological Survey, 1976-83, Water-resources data for Arizona, water years 1975-81: U.S. Geological Survey Water-Resources Data Reports AZ-75-1 to AZ-81-1.

U.S. Geological Survey, 1978, Progress report on Black Mesa monitoring program-1977: U.S. Geological Survey OpenFile Report 78-459, 38 p.

White, N.D., and Garrett, W.B., 1984, Water resources data for Arizona, water year 1982: U.S. Geological Survey WaterData Report AZ-82-1, 440 p.

White, N.D., and Garrett, W.B., 1986, Water resources data for Arizona, water year 1983: U.S. Geological Survey WaterData Report AZ-83-1, 387 p.
White, N.D., and Garrett, W.B., 1987, Water resources data for Arizona, water year 1984: U.S. Geological Survey WaterData Report AZ-84-1, 381 p.

White, N.D., and Garrett, W.B., 1988, Water resources data for Arizona, water year 1985: U.S. Geological Survey WaterData Report AZ-85-1, 343 p.

Wilson, R.P., and Garrett, W.B., 1988, Water resources data for Arizona, water year 1986: U.S. Geological Survey Water-Data Report AZ-86-1, 341 p.

Wilson, R.P., and Garrett, W.B., 1989, Water-resources data for Arizona, water year 1987: U.S. Geological Survey Water-Data Report AZ-87-1, 385 p.

Zhu, Chen., Waddell, R.K., Star, I., and Ostrander, M., 1998, Responses of ground water in the Black Mesa Basin, northeastern Arizona, to paleoclimatic changes during the late Pleistocene and Holocene: Geology, v. 26, no. 2, p. 127-130.

Zhu, Chen., 2000, Estimate of recharge from radiocarbon dating of groundwater and numerical flow and transport modeling: Water Resources Research, v. 36, no. 9, p. 2607-2620. 
Manuscript approved for publication, February 27, 2006

Prepared by the U.S. Geological Survey Publishing Network,

Publishing Service Center, Tacoma, Washington

Bill Gibbs

Bobbie Jo Richey

Publishing Service Center, Salt Lake City, Utah

Steve Longsworth

For more information concerning the research in this report, contact the Director, Arizona Water Science Center

U.S. Geological Survey, 520 N. Park Avenue, Suite 221

Tucson, Arizona 85719

http://az.water.usgs.gov 


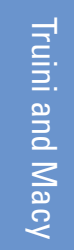

올

愛

象

高

蛋

旁

承

오ำ

㞔

맵

品

芶

蛋

蛋

을

蛋

害

곡.

d

采

윢

응

딩

3 Printed on recycled paper 